\title{
O IMPACTO DO MARKETING “VERDE” NAS DECISÕES SOBRE EMBALAGENS DAS CERVEJARIAS QUE OPERAM NO BRASIL
}

MARCOS FRUET PALHARES

ORIENTADOR: PROF. DR. CELSO CLAUDIO DE HILDEBRAND E GRISI

Dissertação apresentada ao Departamento de Administração da Faculdade de Economia, Administração e Contabilidade da Universidade de São Paulo para obtenção do título de Mestre em Administração.

SÃO PAULO - SP

2003 
FICHA CATALOGRÁFICA

Elaborada pela Seção de Publicações e Divulgação do SBD/FEA/USP

Palhares, Marcos Fruet

O impacto do marketing "verde" nas decis̄es sobre embalagens das eervejarias que operam no Brasil / Marcos

Fruet Palhares. - Sāo Paulo: FEAJUSP, 2003.

$139 \mathrm{f}$.

Dissertaçప̃̌ (Mestrodo) - Universidade de São Paulo, 2003 Bibliografia.

1. Marketing ambiental 2. Comportansento do consumidor 3. Embalagens 4. Desenvolvimento sustentável 1. Faculdade de Eoonomia, Administraç̧̃ó e Contabilidade da USP II. Título. 
Para Gabriela 
“O meio ambiente não deve ser tratado apenas como uma ameaça para a cadeia de embalagens; há também oportunidades para empresas ambientalmente corretas. Não há razão para que um comportamento responsável não seja explorado para gerar lucro, pois, apesar de a virtude ser, ela mesma, uma recompensa, os negócios só podem continuar a ser virtuosos se forem lucrativos e bem-sucedidos. $\mathrm{O}$ meio ambiente só tem a ganhar se eles prosperarem. O objetivo deveria ser explorar os recursos mantendo-se do lado correto da linha verde, sem passar para o lado errado.”

(Levy, 2000: 95) 


\section{AGRADECIMENTOS}

Este trabalho é resultado do esforço de alguns anos partilhados com um grupo de pessoas que, por diferentes motivos, viabilizaram a sua realização. A elas agradeço pela contribuição.

Aos colegas da FEA, especialmente Lúcia, Mário, Oscar, Zanetti, Roberto e Paulo que, em todos os momentos, estiveram presentes;

Ellen, Simos, Andreas, Ola e Gerritjan, colegas da Saïd Business School, na Universidade de Oxford, com quem tive a oportunidade de dividir momentos valiosos de estudo e lazer;

Professor Jonathan Reynolds, de Templeton College, na Universidade de Oxford, que me indicou importante bibliografia;

Andréia Rulli, da British Airways, que viabilizou minha ida para a Inglaterra;

St-Cross College, da Universidade de Oxford, sem a ajuda do qual não teria sido possível minha visita à Interpack 2002, em Düsseldorf;

Revista EmbalagemMarca, que propiciou minha participação no Emballage 2000, em Paris, e na Envase 2003, em Buenos Aires.

Research International, por ceder dados de sua pesquisa sobre o consumidor e o meio ambiente;

Alcan, CSN e Abividro, que me forneceram informações relevantes sobre o mercado de embalagens para cerveja.

Camille Kaufmann, da AmBev, Roberto Garcia, da Kaiser, e Luiz Cláudio Taya de Araújo, da Schincariol, que encontraram tempo em sua concorrida agenda para me receber;

Valéria, da Secretaria de Pós-Graduação da FEA/USP, pela eficiência e boa vontade.

Ana Lúcia, por gentilmente organizar a comunicação com meu orientador.

Prof. Dr. Luiz Hamilton Berton e Prof. Dr. Francisco Antonio Serralvo que, durante o exame de qualificação, deram sugestões fundamentais para a conclusão do trabalho; 
Prof. Dr. Celso Grisi, meu orientador, que muito me ajudou a achar um enfoque apropriado para a pesquisa;

Marilda, Flávia (e Mariana, que chega em breve), Luli e Nani, sempre presentes e parte importante da minha vida;

Flávio e Thays, pelo companheirismo;

Wilson e Eunice, meus queridos pais, que servem de exemplo pela curiosidade intelectual, e que tanto carinho me dedicam;

Babi, referência como pesquisadora, e que há tanto tempo, com muita paciência e jeito, me acompanha, me ajuda, me incentiva, e que comigo dividiu as aflições e as alegrias de todo esse processo, sempre sorrindo. 


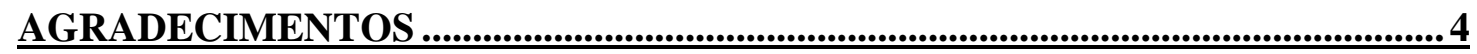

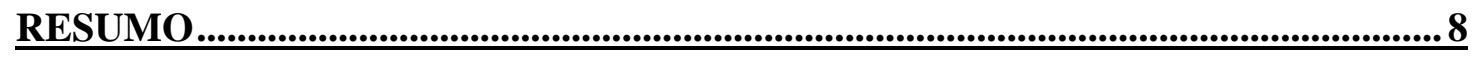

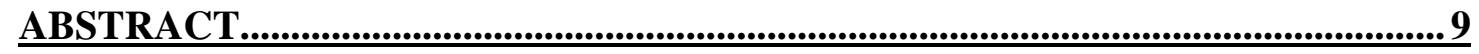

INTRODUCÃ̃

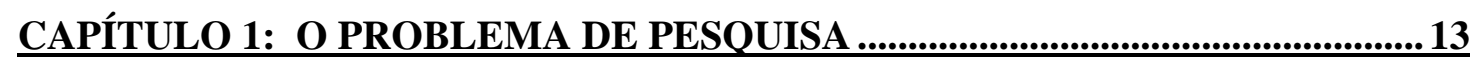

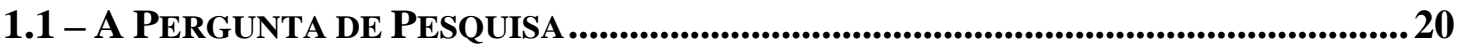

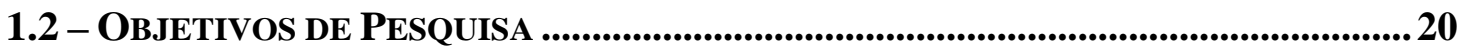

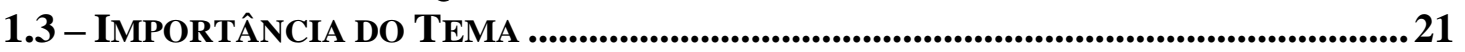

1.4 - ESTRUTURA DO TRABALHO .................................ERRO! INDICADOR NÃO DEFINIDO.

1.5 - LIMITAÇÕES ........................................................................................................................ 119

1.6 - METODOLOGIA .................................................................................................................... 30

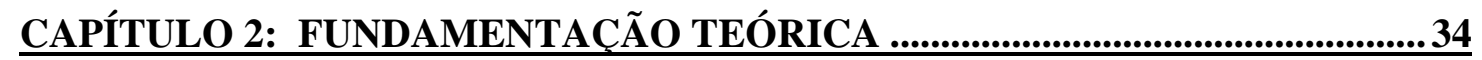

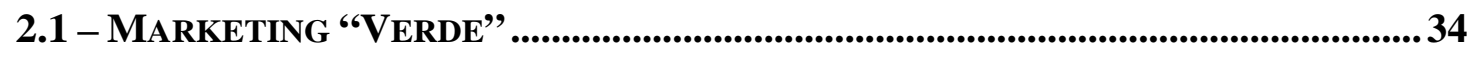

2.2 - DESENVOLVIMENTO SUSTENTÁVEL ....................................................................... 39

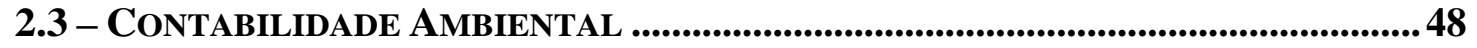

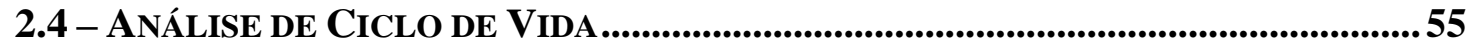

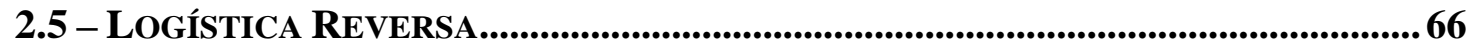

2.6 - COMPORTAMENTO DO CONSUMIDOR_............................................................68

2.7 - COMPORTAMENTO “VERDE” DO CONSUMIDOR ..................................................... 72

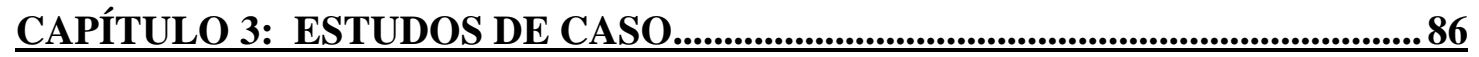

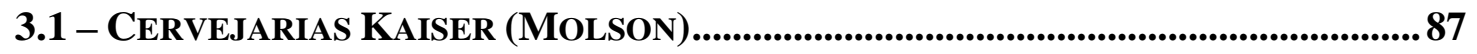

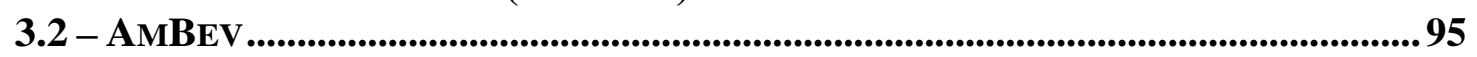

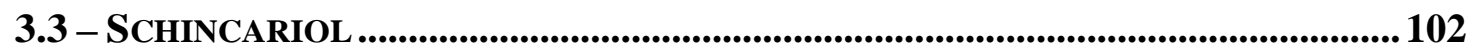

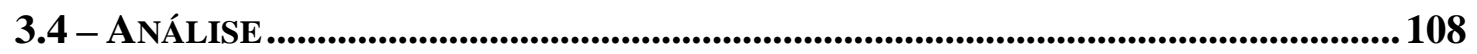




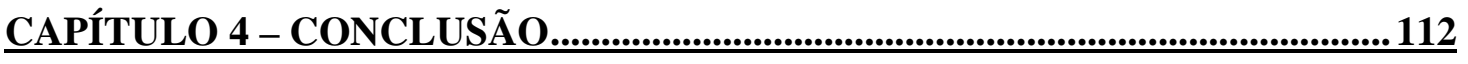

4.1 - IMPLICAÇÕES PARA A TEORIA DE MARKETING ..................................................114

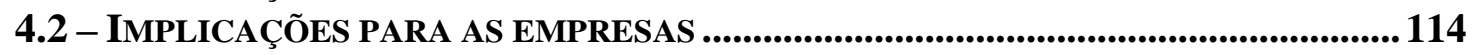

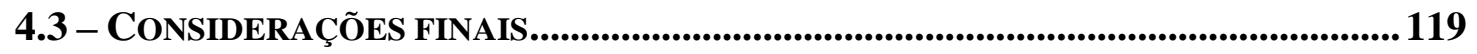

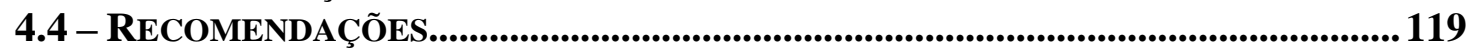

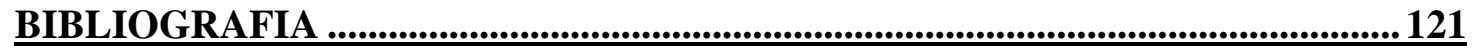

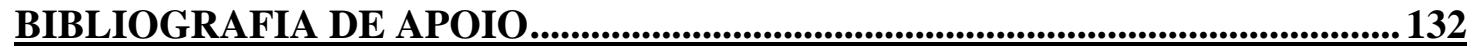

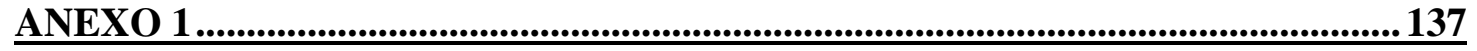




\section{RESUMO}

Nos últimos anos, tem ganhado importância o debate sobre a preservação ambiental. Para responder às crescentes demandas do governo, traduzidas em uma legislação cada vez mais rigorosa, e dos consumidores, expressas em suas preferências no momento de compra, as empresas vêem-se obrigadas a observar cuidadosamente seu desempenho ambiental. Às vezes, contudo, temem-se eventuais incompatibilidades entre ações corporativas orientadas ecologicamente e aquelas direcionadas economicamente.

Esta dissertação concentra suas atenções em embalagens, por serem estas identificadas, muitas vezes, com problemas ambientais, especialmente aqueles relacionados com a questão do lixo urbano. Partindo da análise de três casos da indústria cervejeira no Brasil, procurou-se identificar como - e se - a dimensão "verde" tem afetado as decisões sobre embalagem nas empresas de bens de consumo.

Recorrendo à bibliografia produzida na área de marketing "verde”, comportamento "verde” do consumidor e desenvolvimento sustentável, este trabalho mostra que ações “ambientalmente corretas” não são necessariamente incompatíveis com o bom desempenho econômico das empresas. Mais que isso, evidencia que o uso de ferramentas como a contabilidade ambiental, a análise de ciclo de vida e a logística reversa podem auxiliar na obtenção de vantagem competitiva. 


\begin{abstract}
In recent years, the debate about environmental preservation has gained importance. In order to respond to growing demands from the government, in the form of an ever more stringent legislation, and from the consumers, expressed by their preferences in buying situations, companies see themselves forced to watch carefully their environmental performance. Sometimes, though, it is feared that there are trade-offs between environmentally and economically oriented corporate actions.

This dissertation puts packaging in the spotlight, because packages are, very often, closely identified with environmental problems, especially those related to urban waste issues. From the analysis of three cases in the Brazilian beer industry, it is sought here to identify how - and if - the "green" dimension has affected packaging decisions in consumer goods industries.

Referring to bibliography on "green” marketing, "green” consumer behaviour, and sustained development, this research shows that "environmental correctness” and good economic performance are not necessarily antagonistic goals. More than that, it shows that the use of tools such as environmental accountability, life cycle assessment, and reverse logistics can help companies to obtain competitive advantage.
\end{abstract}




\section{INTRODUÇÃO}

O presente trabalho tem por objetivo verificar, à luz do marketing "verde”, se é possível que se perceba, entre as cervejarias que operam no Brasil, alguma influência de fatores ligados à proteção do meio ambiente nas decisões relativas aos tipos de embalagens com que essas empresas decidem competir pelos recursos dos consumidores. O que se quer investigar é se os principais fabricantes de cerveja estão considerando em suas escolhas uma possível preferência, por parte de seu públicoalvo, por embalagens menos danosas ao meio natural.

A idéia de se trabalhar com o comportamento do consumidor ligado a estímulos com apelo ecológico advém do fato de que a recuperação e a reciclagem de resíduos sólidos já vêm sendo alvo de discussão na cadeia produtiva, constituindo-se numa possível fonte de vantagem de determinados materiais de embalagem sobre outros (EmbalagemMarca, 2001a).

A escolha do setor cervejeiro como foco da análise deve-se ao fato de que as cervejarias têm à sua disposição embalagens feitas de diferentes materiais - latas de alumínio e de aço, garrafas de vidro e vasilhames plásticos (de PET - polietileno tereftalato - e de PEN - polietileno naftalato), todos com diferentes propriedades físico-químicas que tornam a sua recuperação mais ou menos vantajosa em termos econômicos (Calderoni, 1997; Murray, 1997), o que faz com que o impacto ambiental de cada material seja singular. Além disso, essa indústria possui uma característica que a torna muito atraente para um estudo como o que aqui é proposto: além das embalagens já tradicionais no mercado - garrafas de vidro e latas de alumínio $^{1}$-, nos quais é envasada quase a totalidade da produção brasileira de cerveja, há dois materiais - o aço e o plástico ${ }^{2}$ - que buscam o aumento de sua participação (BB\&PA, 2001; Butler, 2000; EmbalagemMarca, 2003a; Food

\footnotetext{
1 As embalagens metálicas retornáveis (os "barris de chope”), por não serem escolhidas pelo consumidor final e por não possuírem embalagem substituta foram excluídas da presente análise.

2 O PET e o PEN serão tratados, daqui para frente, indistintamente como “embalagens plásticas”, a menos que especificado em contrário.
} 
Engineering, 2000; Pack Report, 2002; Packaging Digest, 2000; Packaging Technology and Engineering, 1998; Toleken, 1999; Weggeman, 2000, 2001; Zoltak, 2001). O ponto interessante é que, dadas as diferenças entre os materiais em termos de reciclabilidade, a consideração da dimensão ecológica nas decisões das cervejarias relacionadas com a escolha de suas embalagens pode significar uma maior ou menor dificuldade para a entrada desses novos materiais, bem como uma ameaça ou oportunidade para os materiais já com participação consolidada, fenômeno que deverá ser notado ao longo da pesquisa.

Para a presente dissertação, optou-se por trabalhar com entrevistas em profundidade com executivos das principais cervejarias que atuam no Brasil para que se pudesse entender (a) como se dá o processo decisório sobre embalagens nessas empresas, (b) quais os fatores que influenciam essas escolhas e (c) de que forma o marketing “verde” tem afetado essas decisões.

Para atingir os objetivos desta pesquisa, o autor decidiu dividi-la em quatro capítulos. No Capítulo 1, serão apresentados o problema de pesquisa, a pergunta e os objetivos do trabalho e a importância do tema. Serão tecidos, nesse capítulo, comentários a respeito da relação entre embalagens e o meio ambiente e sobre os tipos de embalagem utilizados pela indústria cervejeira no mercado brasileiro. Em seguida, a preocupação será com uma descrição do atual estágio em que se encontram as discussões teóricas sobre os temas abordados (Capítulo 2). Dessa forma, far-se-á uma revisão bibliográfica sobre marketing "verde” e comportamento "verde" do consumidor. Como temas de suporte, serão discutidos os conceitos de desenvolvimento sustentável, contabilidade ambiental, análise de ciclo de vida e logística reversa.

A revisão teórica dessa primeira parte servirá de base para uma segunda etapa, onde serão analisadas as entrevistas feitas com executivos que têm poder de decisão nas principais cervejarias que operam no Brasil (Capítulo 3), com o objetivo de responder as perguntas de pesquisa. Após a apresentação dos casos, procurar-se-á identificar como são tomadas as decisões sobre embalagens nas empresas que 
compõem o estudo, quais são os fatores que conduzem essas decisões e qual é a importância que, nessa indústria específica, se dá à questão do marketing "verde” no momento em que se escolhem as embalagens. Finalmente, com base na discussão teórica e nos estudos de caso, procurar-se-á enumerar algumas das implicações para a teoria de marketing e para as empresas (Capítulo 4). 


\section{CAPÍTULO 1: O PROBLEMA DE PESQUISA}

O mercado de cervejas no Brasil passa por um momento de reestruturação, acelerado em meados de 1999 pela criação da AmBev - Companhia de Bebida das Américas $^{3}$. Novos fabricantes entraram no Brasil (a canadense Molson, por exemplo, adquiriu a Cervejarias Kaiser em 2003 - Datamark, 2003), novas empresas nacionais surgiram (como a Frevo Brasil, de Pernambuco, que começou a fabricar cervejas em meados de 2003 - Datamark, 2003), e acirrou-se a disputa por uma parcela de um mercado grandioso (EmbalagemMarca, 2003b).

O Brasil é o quarto maior fabricante de cerveja do mundo, com um volume anual de cerca de 8,41 bilhões de litros (R\$ 14,5 bilhões), segundo dados do Sindicerv referentes ao exercício de 2002. Superam o Brasil, em volume anual de produção, apenas os Estados Unidos (23,6 bilhões de litros/ano), a China (18 bilhões de litros/ano) e a Alemanha (11,7 bilhões de litros/ano). O consumo per capita no Brasil teve um grande crescimento nos primeiros dois anos do Plano Real (1994 e 1995), saltando de um patamar de 38 litros/ano por pessoa para 50 litros/ano/habitante. Desde então, o nível se mantém estável. De 1998 a 2003, as indústrias cervejeiras investiram mais de R\$ 3 bilhões no Brasil, abrindo 10 novas plantas industriais e ampliando e modernizando fábricas já existentes. O setor é responsável hoje por cerca de 150000 empregos diretos e indiretos (Sindicerv, 2003).

Fornecedores de embalagens para essa indústria, por sua vez, têm investido em tecnologias que melhoram a qualidade de latas e garrafas e que reduzem custos (Interpack, 2002), e têm incluído, com certa freqüência, apelos ecológicos em suas estratégias de comunicação para a indústria usuária (EmbalagemMarca, 2001a).

\footnotetext{
${ }^{3}$ A fusão entre a Brahma e a Antarctica, à época as duas maiores cervejarias brasileiras, foi aprovada pelo Conselho Administrativo de Defesa Econômica (Cade) em março de 2000 (Brasil, Ministério da Justiça, 2000)
} 
Nos últimos anos, aliás, o tema "proteção do meio ambiente” e suas relações com o debate sobre o descarte de resíduos sólidos têm ganhado corpo, especialmente em países avançados (Fernie \& Hart, 2001; Fishbein, 2000; Frey, 1999; Hitchens et al., 2000; Kalafatis et al., 1999; Levy, 2000; Livingstone \& Sparks, 1994; Mainieri et al., 1997; Murray, 1999; Peattie, 1992, 1999, 2001; Polonsky \& Rosenberger III, 2001; Porter \& Van der Linde, 1995; Stern, 1999; Wagner, 1997; Wells, 2000; Williamson, 2000). A União Européia, por exemplo, dentro de seu objetivo de harmonizar as legislações existentes nos diferentes países-membro (Bailey, 1999), promulgou, via Parlamento Europeu, uma abrangente e detalhada Diretiva que trata especificamente do assunto “embalagem e descarte de embalagem”, a 94/62/EC on Packaging and Packaging Waste (EC, 1994), que estabelece rigorosos níveis de recuperação e reciclagem de resíduos sólidos em cada país-membro, e que torna toda a cadeia produtiva co-responsável pelo atingimento dessas metas. Se, por um lado, a Diretiva exige da cadeia de embalagens uma movimentação em direção à redução, à reutilização e à reciclagem de embalagens, a regulamentação prevê, por outro lado, um amplo debate com a sociedade civil na busca de soluções para a questão dos resíduos sólidos.

Nesses debates, a informação é vista como fundamental para despertar e reforçar no consumidor comportamentos que auxiliem os países a atingir os níveis elevados de recuperação e reciclagem de resíduos sólidos (DETR, 2000; EC, 1994). O fundamento teórico por trás disso pode ser extraído de estudos de comportamento do consumidor que têm uma abordagem cognitiva (Chisnall, 1995; Wagner, 1997). Além da informação, discute-se a importância de diferentes tipos de incentivos na tentativa de conduzir os consumidores a adotar padrões de consumo ambientalmente mais saudáveis (Frey, 1999; Nyborg, 1999; Thøgersen, 1999).

Por faltarem elementos que permitam assumir que a situação no Brasil será semelhante àquela vigente na União Européia ${ }^{4}$, inferir que por aqui se seguirão os

\footnotetext{
${ }^{4}$ Pearce et al. (1992) comentam que, apesar de países pobres serem mais afetados que os ricos pela degradação ambiental, há indicativos de que o valor que se dá ao meio ambiente é maior nos países mais ricos. Os autores sugerem haver uma correlação positiva entre PIB per capita e "vontade de agir em benefício do ambiente", mas fazem a ressalva de que "vontade de agir" não é o mesmo que "vontade de pagar mais".
} 
mesmos passos trilhados no Velho Continente seria, no mínimo, imprudência. Porém, alguns fatores sugerem que o consumidor brasileiro também deve tomar contato com a questão do descarte de embalagens e seu impacto sobre o meio ambiente - o que, recorrendo novamente a Wagner (1997), seria um ingrediente importante para a criação de um contexto favorável ao desenvolvimento do que se chamará nesta dissertação de comportamento "verde" do consumidor - hábitos de consumo que privilegiem produtos cuja utilização e descarte tenham menor impacto sobre o meio ambiente.

Primeiro, há que se mencionar que, tendo por base justamente a Diretiva européia, tramita no Congresso Nacional um projeto de lei que atribui à cadeia produtiva responsabilidade pela recuperação e reciclagem das embalagens descartadas pelo consumidor. Em sendo aprovado o projeto, as empresas terão de mobilizar o consumidor para poder recuperar as embalagens usadas (EmbalagemMarca, 2001b).

Em segundo lugar, a atividade de recolhimento de materiais recicláveis por parte dos chamados “catadores" ou "sucateiros" (pessoas que recolhem materiais com valor de revenda para diversos fins, principalmente a reciclagem, nas ruas, nos lixões e nas residências das pessoas) transformou-se em meio de subsistência de uma parcela da população de baixa renda ${ }^{5}$, impulsionando os índices de reciclagem de determinados materiais ${ }^{6}$ (Calderoni, 1997; Wells, 2000). Para dar uma dimensão do tamanho do mercado para produtos destinados à reciclagem no Brasil, estimativas dão conta de que, no ano de 2002, se movimentaram cerca de R\$ 4 bilhões com o comércio de resíduos, montante que pode vir a crescer com a maior organização da atividade de reciclagem no país ${ }^{7}$. Nesse sentido, a Assembléia Legislativa do Estado

\footnotetext{
${ }^{5}$ Estima-se que existam no país cerca de 2.500 cooperativas ou instituições similares, envolvendo diretamente pelo menos 80.000 pessoas. Atuam na coleta e comercialização de materiais recicláveis, representando o elo da cadeia da reciclagem mais próximo da população (AmBev, 2003).

${ }^{6}$ O Brasil possui, por exemplo, os mais altos índices de reciclagem de latas de alumínio entre os países onde a reciclagem não é obrigatória (EmbalagemMarca, 2003a).

${ }^{7}$ Na cidade de São Paulo, a taxa de lixo urbano domiciliar coletado pelo município de forma seletiva, em meados de 2003, era de apenas $1 \%$ - índice que a Prefeitura desse município promete elevar para $10 \%$ em 2004 (FSP, 2003)
} 
de São Paulo, visando a reduzir o ritmo de esgotamento de aterros sanitários, estuda instituir mecanismos de incentivo a empresários que atuem na coleta e na reciclagem do lixo (FSP, 2003). É possível ainda que, dado o trabalho de coleta porta-a-porta realizado por esses “catadores”, ou mesmo em função da instituição de programas de coleta seletiva, cresça o número de consumidores que mantenham um contato, esporádico ou regular, com a questão do descarte de embalagens.

Em terceiro lugar, é preciso mencionar que, nos grandes centros urbanos brasileiros, um fator adicional pode contribuir para o aumento na intensidade com que tal tema seja discutido: o esgotamento iminente da capacidade dos aterros sanitários. O município de São Paulo, por exemplo, onde se produzem diariamente cerca de 15000 toneladas de lixo, prevê o esgotamento da capacidade de seus dois aterros (Bandeirantes e São João) já em 2007 (Brasil, PMSP, 2003). Os moradores dessa cidade muito provavelmente entrarão em contato com o debate sobre o descarte dos resíduos sólidos, seja por acompanharem as discussões nos meios de comunicação, seja por serem forçados a arcar com os custos do sistema de coleta de lixo no município, através, por exemplo, de mecanismos como a recém-instituída “Taxa do Lixo"8.

Finalmente, há que se ressaltar que as empresas que compõem o universo desta pesquisa já incorporaram, em sua comunicação, a importância da preservação ambiental. Numa pesquisa que o autor realizou, em junho de 2003, nos sites das principais cervejarias do Brasil $^{9}$, dos principais fornecedores de embalagens para esta indústria ${ }^{10}$ e de entidades ou empresas representativas tanto dos diferentes materiais $^{11}$ quanto das cervejarias ${ }^{12}$, notou-se que quase todos (há apenas uma

\footnotetext{
${ }^{8}$ No início de 2003, a Prefeitura Municipal de São Paulo anunciou a criação de uma taxa que incide sobre o volume estimado de lixo produzido em unidades domiciliares e comerciais, cujo objetivo declarado é o de arrecadar fundos para custear o sistema de coleta de lixo na cidade (Brasil, PMSP, 2003). Em países avançados, esse tipo de taxação também existe. Em julho de 2002, por exemplo, a Unidade de Inovação e Desempenho, organismo do governo britânico, começou a discutir a instituição da cobrança de uma taxa mensal sobre o lixo domiciliar produzido. A medida teria como objetivo de elevar os índices de recuperação e reciclagem de materiais no Reino Unido (FT, 2002).

${ }_{9}^{9}$ AmBev, Cervejaria Petrópolis, Kaiser, Schincariol

${ }^{10}$ Amcor, Cisper, CIV, Crown Cork, Latapack Ball, Latasa, Metalic, Saint-Gobain, Sidel e Tetra Pak

${ }^{11}$ Abiplast - Associação Brasileira da Indústria do Plástico, Abividro - Associação Técnica Brasileira das Indústrias Automáticas de Vidro, Alcan, CSN

${ }^{12}$ Sindicerv - Sindicato Nacional da Indústria da Cerveja
} 
exceção) têm um espaço dedicado à atuação da empresa (ou do setor a que pertence ou que representa) na conservação do meio ambiente.

Os resultados dessa pesquisa estão tabulados no quadro 1.1, apresentado na próxima página. Resta saber se as cervejarias estão incorporando esse discurso às suas práticas, e se isto está afetando as suas decisões sobre embalagens. 


\begin{tabular}{|c|c|c|c|}
\hline Empresa & O que faz & $\begin{array}{c}\text { Preservação } \\
\text { ambiental no } \\
\text { site? }\end{array}$ & URL \\
\hline Abividro & Associação & Sim & www.abividro.org.br \\
\hline Alcan & $\begin{array}{l}\text { Chapas de } \\
\text { alumínio para } \\
\text { latas }\end{array}$ & Sim & www.alcan.com.br \\
\hline AmBev & Cervejas & Sim & www.ambev.com.br \\
\hline Amcor & $\begin{array}{l}\text { Embalagem PET } \\
\text { para cerveja }\end{array}$ & Sim & www.amcor.com $(*)$ \\
\hline $\begin{array}{l}\text { Cervejaria } \\
\text { Petrópolis }\end{array}$ & Cervejas & Sim & www.cervejariapetropolis.com.br \\
\hline Cisper & Garrafas de Vidro & Sim & www.cisper.com.br \\
\hline CIV & Garrafas de Vidro & Sim & www.civ.com.br \\
\hline $\begin{array}{l}\text { Crown Cork do } \\
\text { Brasil }\end{array}$ & Latas de alumínio & Sim & www.crowncork.com $(*)$ \\
\hline CSN & $\begin{array}{l}\text { Chapas de aço } \\
\text { para latas de } \\
\text { bebidas }\end{array}$ & Sim & www.csn.com.br \\
\hline Kaiser & Cervejas & Sim & www.kaiser.com.br \\
\hline Latapack Ball & Latas de alumínio & Sim & www.ball.com $(*)$ \\
\hline Latasa & Latas de alumínio & Sim & www.latasa.com.br \\
\hline Metalic & Latas de aço & Sim & www.metalic.com.br \\
\hline Rexam Can & Latas de alumínio & Sim & www.rexamcan.com.br \\
\hline $\begin{array}{l}\text { Saint-Gobain } \\
\text { Embalagens }\end{array}$ & Garrafas de Vidro & Sim & $\begin{array}{l}\text { www.saint-gobain- } \\
\text { embalagens.com.br }\end{array}$ \\
\hline Schincariol & Cervejas & Sim & www.schincariol.com.br \\
\hline Sidel & $\begin{array}{l}\text { Embalagem PET } \\
\text { para cerveja }\end{array}$ & Não & www.actis-tm.com $(*)$ \\
\hline Sindicerv & Associação & Sim & www.sindicerv.com.br \\
\hline Tetra Pak & $\begin{array}{l}\text { Embalagem PET } \\
\text { para cerveja }\end{array}$ & Sim & www.tetrapak.com.br \\
\hline
\end{tabular}

(*) Não possui site local/o site não está concluído. Visitado o site da matriz

Quadro 1.1 - A presença do discurso sobre preservação do meio ambiente no site de cervejarias, de seus fornecedores de embalagens e de organizações e entidades representativas dessas empresas (Fonte: Internet) 
Com o que foi colocado acima, quer-se mostrar que no Brasil, a exemplo do que já ocorre em países avançados (Levy, 2000), pode haver espaço para o fortalecimento de um contexto em que as empresas precisem familiarizar-se com conceitos como marketing "verde" e comportamento "verde" do consumidor (ver definições no capítulo 2).

Alguns dados indicam que o consumidor brasileiro já acordou para a questão ambiental. Levantamento realizado pela Research International em meados de 2002 (Research International, 2002), por exemplo, mostram que 94,7\% dos brasileiros já tinham ouvido falar em reciclagem ou materiais recicláveis, índice que chegou a 100\% na classe A, e atingiu 89,6\% nas classes D/E. Números semelhantes foram obtidos quando se utilizou a variável grau de escolaridade para separar os respondentes: $100 \%$ entre as pessoas com nível superior completo e 85,4\% entre aqueles com primeiro grau incompleto ou sem educação formal já tinham ouvido falar no assunto.

Quando perguntadas sobre a posição em relação à reciclagem, 27\% das pessoas entrevistadas afirmaram já separar materiais para esse fim, 34\% disseram ser muito simpáticos à possibilidade de adotar o hábito, 13\% declararam-se muito predispostos a seguir essa rotina e $23 \%$ admitiram não estar muito preocupados com isso. Cerca de 3\% não souberam informar. As diferenças sócio-econômicas, nesse caso, também são relevantes. Enquanto 36,6\% das pessoas de classe A disseram já separar o lixo de casa para a reciclagem, o índice nas classes D/E foi de apenas 20,5\%. Inversamente, aqueles que não se preocupam com a reciclagem são apenas $12,2 \%$ na classe $\mathrm{A}$, e 31,4\% nas classes D/E. Somados os índices de predisposição para reciclar e simpatia pela possibilidade de adotar o hábito, os números são de 53,6\% entre indivíduos da classe A e 40,8\% entre pessoas das classes D/E.

O grau de instrução também influencia a posição das pessoas em relação à separação de materiais para reciclagem. Os números foram maiores entre os entrevistados com nível superior completo do que entre os sem educação formal ou primeiro grau incompleto para os itens “já separo o lixo de casa para reciclagem” (38,5\% contra 23,8\%), “vejo com simpatia a possibilidade de adotar esse hábito” (32,3\% contra 23,1\%) e "ainda não reciclo, mas estou muito predisposto” (21,5\% 
contra 6,9\%). Por outro lado, os números se inverteram quando o item era "não me preocupo ainda com isso” (9,2\% entre pessoas da classe A, e 33,8\% entre pessoas das classes $\mathrm{D} / \mathrm{E})$.

Esses dados sugerem que a informação parece ser, de fato, um elemento fundamental no desenvolvimento de comportamentos ambientalmente melhores por parte dos consumidores, corroborando a perspectiva cognitiva seguida nesse trabalho. Por outro lado, indicam que a baixa renda do consumidor pode ser um fator que inibe tais comportamentos.

\section{1 - A Pergunta de Pesquisa}

Esta dissertação tenta identificar, portanto, se esse contexto favorável à difusão de assuntos “verdes” - relacionados com a preservação do meio natural - encontra ressonância nas decisões sobre embalagens tomadas hoje nas cervejarias brasileiras. Assim, o trabalho que aqui se desenvolve procura responder a seguinte pergunta:

Como o marketing "verde" tem afetado as decisões sobre embalagens tomadas nas cervejarias que atuam no Brasil?

Ao mostrar como a dimensão ecológica está sendo incorporada nos processos decisórios dessas empresas, pretende-se apontar a contribuição que as decisões sobre embalagens pode dar na busca pelo desenvolvimento sustentável.

\section{2 - Objetivos de Pesquisa}

O objetivo principal desse trabalho é, portanto, identificar qual o impacto que o comportamento "verde” do consumidor está tendo nas decisões das cervejarias sobre as embalagens que utilizam. Quer-se saber se esse tema pode fazer com que a indústria cervejeira passe a adotar estratégias de embalagem orientadas pelo 
marketing "verde" (ações de marketing orientadas para a preservação do meio ambiente), ou se essa será uma questão de menor importância.

Como objetivos secundários, esta dissertação pretende (a) averiguar quais são os principais fatores que influenciam a tomada de decisão sobre embalagens nas maiores cervejarias brasileiras, e qual a importância relativa de cada um desses fatores, e (b) perceber se poderá haver alguma mudança na divisão do mercado de cerveja entre os diferentes materiais de embalagem, como conseqüência de seu maior ou menor impacto ambiental.

\section{3 - Importância do Tema}

Se esse contexto que se descreveu anteriormente como sendo favorável ao fortalecimento de ações alinhadas com o marketing "verde" de fato se consolidar, levando legisladores, a mídia e principalmente os consumidores a associar - a exemplo do que se observa na Europa - embalagens à degradação do meio ambiente (Levy, 2000), será fundamental para as empresas de bens de consumo a incorporação da análise do comportamento "verde" do consumidor em suas decisões sobre embalagens. No caso da indústria cervejeira, essa dimensão pode alterar tal processo decisório, modificando a participação de cada tipo de embalagem no mercado.

Dessa forma, torna-se conveniente entender o comportamento "verde" do consumidor, qual a importância da informação nesse processo e como motivar o consumidor a agir de maneira ecologicamente "correta", com o intuito de se verificar se estratégias de posicionamento baseadas em escolhas de embalagens fundamentadas em aspectos ecológicos poderiam atrair os consumidores para determinadas marcas, o que, por sua vez, poderia ser uma razão para que essa dimensão "verde” passe a ser relevante para as cervejarias nas suas decisões sobre embalagens.

O processo de posicionamento envolve várias ferramentas interligadas que afetam o composto de marketing como um todo (Cravens, 1994). Na indústria cervejeira, em nível mundial, preços (Biffa, 2000), marcas e embalagens (Mintel, 
2001a) são três das mais importantes dentre essas ferramentas. Este estudo vai concentrar-se na última, o que não significa, de maneira alguma, que se considera que esta dimensão seja mais importante que as demais. A embalagem, aqui, está no centro da análise porque é a interface tangível entre a empresa e o consumidor, entre o consumidor e o ambiente e, portanto, entre a empresa e o ambiente.

1.3.1 - A embalagem e o meio ambiente: As embalagens são vistas por muitos como um dos maiores problemas das sociedades industriais modernas, sendo rotuladas, às vezes, como as grandes vilãs ambientais. Isto se deve, em grande parte, ao fato de que as embalagens compõem uma importante fração do volume observável de lixo urbano (Fernie \& Hart, 2001; Levy, 2000; Livingstone \& Sparks, 1994; Peattie, 1992). Considerando-se que garrafas, latas e outros tipos de embalagens normalmente carregam marcas, a indústria de bens de consumo está, de uma maneira ou de outra, associada a este problema, como o estão, em maior ou menor escala, outras indústrias na cadeia de embalagem.

Pressionadas pelo potencial negativo que essa ligação entre marca e geração de lixo (com a conseqüente degradação da qualidade de vida das pessoas) pode ter para a sua imagem, fabricantes de bens de consumo vêem-se, cada vez mais, forçados a repensar suas embalagens, com o objetivo de diminuir o volume de lixo criado por elas (Levy, 2000). Há, entretanto, limites para a redução no volume e/ou no peso das embalagens, impostos por barreiras técnicas e aspectos logísticos. Nesse caso, a reutilização e a reciclagem das embalagens descartadas passam a ser as alternativas para minimizar a quantidade de lixo depositada no meio-ambiente (DEFRA, 2001a) que devem ser consideradas pelas empresas usuárias de embalagem.

1.3.2 - Consumerismo “verde”: Além disso, a opinião do consumidor a respeito das questões ambientais pode ser outro fator a pressionar a indústria em suas escolhas de embalagens. Não há poder maior nas mãos do consumidor do que a sua decisão de compra. No caso de aspectos ambientais serem considerados no momento em que marcas e produtos são avaliados pelas pessoas, a imagem de responsabilidade ambiental pode ser decisiva (Wagner, 1997). Afinal, se por um lado 
as atitudes dos consumidores com relação a empresas e marcas que não sejam vistas como empenhadas em reduzir os volumes de lixo podem ser de mera indiferença (se as embalagens usadas não forem vistas como parte agravante do problema do lixo urbano, ou se esta não for considerada uma questão relevante), por outro podem levar a situações mais delicadas para a imagem das corporações.

Ao estudar uma atitude mais radical e coordenada dos consumidores insatisfeitos com a postura das empresas - os boicotes - Sen et al. (2001) chamam a atenção para o fato de que, dado o avanço tecnológico que facilita e barateia a difusão de informações (um bom exemplo desse fenômeno é a Internet) e a maior organização de grupos ativistas, os boicotes a produtos ou marcas podem constituir uma ameaça concreta a organizações que não souberem reduzir o descontentamento dos consumidores com relação a fatores dos mais diversos.

Esses acadêmicos destacam que a decisão individual de deixar de consumir um bem que se deseja em nome de "ganhos sociais ou econômicos coletivos”, fenômeno que eles chamam de "dilema social”, é influenciada pela expectativa de que haja grande adesão ao boicote. Sen et al. consideram, ainda, que a probabilidade de participação em boicotes pode ser alavancada pela existência de produtos substitutos. No contexto da presente dissertação, essa última observação é de grande importância, pois sugere que, caso haja um descontentamento muito grande com as cervejarias no que se refere à postura delas frente a questão ambiental, uma marca que tenha se posicionado como ambientalmente "mais correta” pode se beneficiar.

Assim sendo, é possível que, num futuro não muito distante, embalagens “desnecessárias” e/ou materiais não-reciclávéis tornem a comercialização de alguns produtos muito difícil. Nem sempre, porém, as embalagens vistas como desnecessárias de fato o são, e nem todos os consumidores são capazes de distinguir produtos com excesso de embalagens daqueles que foram concebidos dentro de parâmetros ecológicos, ou de entender o verdadeiro impacto ambiental de diferentes materiais de embalagem (EmbalagemMarca, 2001a). Um fator que contribui para isso é o fato de a embalagem desempenhar funções que acabam por exigir dela determinadas características que, aos olhos dos consumidores, podem parecer excessos. De acordo com Livingstone e Sparks (1994), essas funções são: 
1) Acondicionar, para que os produtos possam ser transportados.

2) Proteger o conteúdo.

3) Preservar as características do produto.

4) Porcionar, ou criar porções adequadas à situação de consumo a que o produto se destina.

5) Unitizar, ou viabilizar o acondicionamento em unidades que sejam apropriadas a cada etapa do processo logístico.

6) Comunicar as informações relevantes.

7) Apresentar, ou promover, o produto no ponto-de-venda.

Como se pode observar, apenas a sétima função abre espaço para o uso desnecessário de embalagens. Mesmo assim, dadas as pressões competitivas, a utilização de embalagens em excesso parece pouco plausível para a maior parte dos bens de consumo, visto que representam custo extra para as empresas.

O desafio para as pessoas envolvidas no dia-a-dia das empresas com as decisões de embalagens - especialmente das de bens de consumo, cujas embalagens acabam por ter contato mais direto com o consumidor final, como é o caso da cerveja - é, portanto, extremamente complexo: por um lado, há que se assegurar que os produtos pelos quais são responsáveis obedeçam as exigências legais e as demandas dos consumidores, sendo atraentes no ponto-de-venda, eficientes nas linhas de enchimento e no transporte e eficazes na proteção dos produtos que acondicionam, sem perder de vista o impacto que podem ter sobre o custo final do produto; por outro lado, deve-se tomar cuidado para evitar que os produtos que carregam as marcas de que cuidam sejam vistos como "geradores de lixo", ainda que tal percepção seja descabida. Esse desafio no desenvolvimento de embalagens pode ser visto na figura 1.1. 


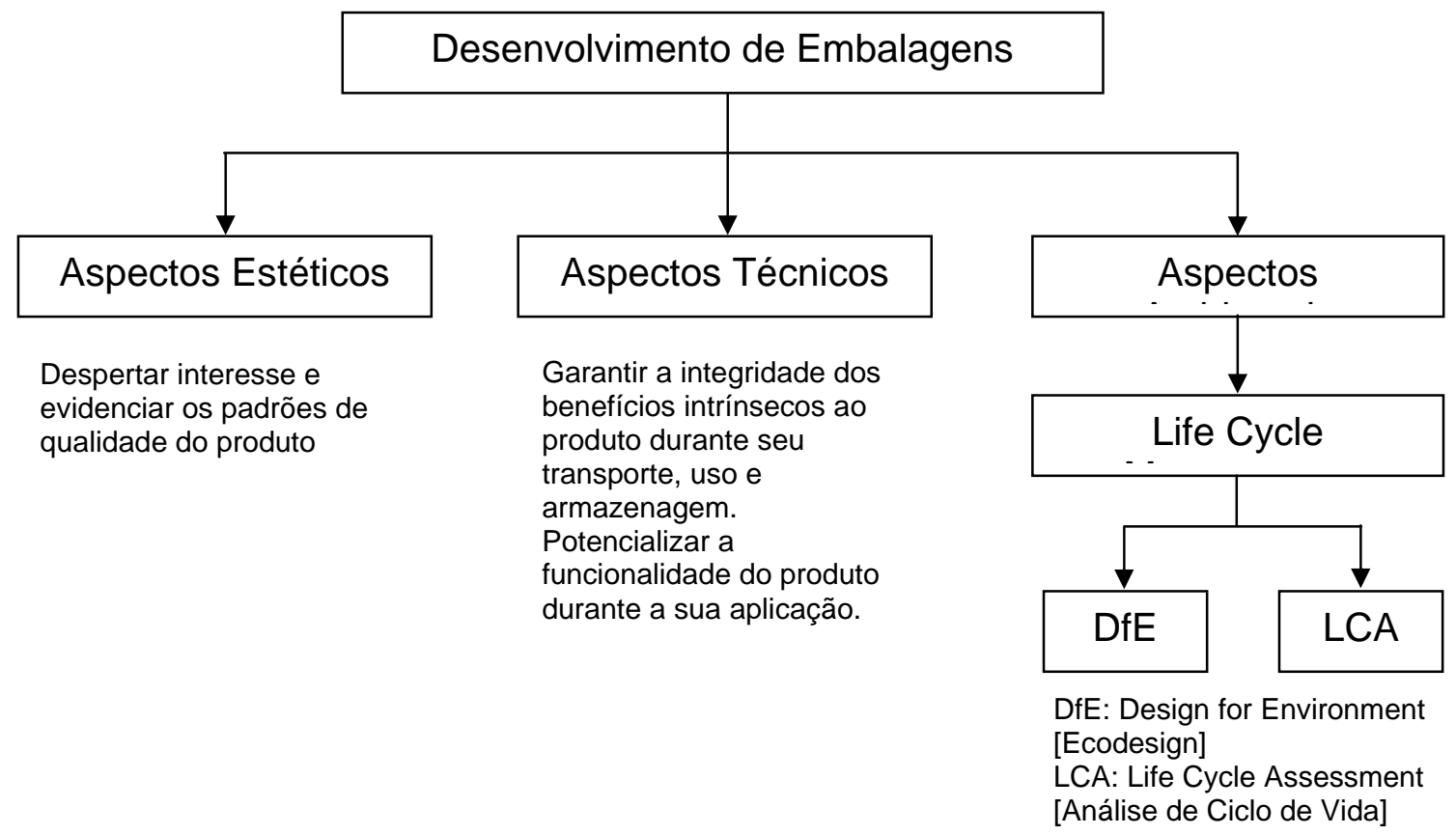

Fig. 1.1 - Os desafios no desenvolvimento de embalagens (Fonte: Mendes, 2003)

1.3.3 - Embalagens no mercado de cervejas: No que diz respeito especificamente ao mercado em que esta dissertação se concentra, é importante que se analisem os diferentes tipos de embalagem disponíveis. As garrafas de vidro, descartáveis e retornáveis, e a lata de alumínio detêm quase que a totalidade do mercado brasileiro de cerveja, mas avanços tecnológicos na produção de recipientes de PET (polietileno tereftalato) e de PEN (polietileno naftalato) para cerveja podem ameaçar esta supremacia (Butler, 2000; EmbalagemMarca 2003b; Food Engineering, 2000; Pack Report, 2002; Packaging Digest, 2000; Packaging Technology and Engineering, 1998; Toleken, 1999; Zoltak, 2001). No Brasil, o surgimento, em 1996, da Metalic, empresa criada para produzir latas de aço de duas peças para o mercado de bebidas, criou condições para que esse metal se tornasse uma alternativa viável para o acondicionamento de cerveja (Metalic, 2003). Hoje, a divisão do mercado, por material de embalagem, é a seguinte ${ }^{13}$ : as garrafas descartáveis de vidro têm

\footnotetext{
${ }^{13}$ Os dados referem-se a 2002
} 
cerca de 2,5\% de participação; as retornáveis do mesmo material possuem 67,7\%; as latas de alumínio respondem por 27,2\% desse mercado; e as latas de aço detêm 0,8\%. O restante é acondicionado em barris de aço (chope). As embalagens plásticas ainda não têm participação registrada no mercado brasileiro de cervejas (Datamark, 2003).

No que se refere ao objeto deste estudo, entretanto, cada material possui vantagens e desvantagens intrínsecas, que - para efeitos de análise - podem ser agrupadas em três categorias principais: custo, apelo mercadológico e reciclabilidade ${ }^{14}$.

1.3.3.1 - Vidro: A imagem de alta qualidade associada ao material parece ser um dos fatores que tem impulsionado as cervejarias em ações de segmentação de mercado, como ocorreu com o lançamento da cerveja Skol Beats, no final de 2002 (EmbalagemMarca, 2002). O material mantém posição confortável no mercado brasileiro de cervejas graças à alta participação das garrafas retornáveis de $600 \mathrm{ml}$, que dominam quase 70\% das vendas no país (EmbalagemMarca 2003b).

Para preservar sua parcela nesse mercado disputado também pelas embalagens metálicas e plásticas, as vidrarias continuam investindo em novas tecnologias para aprimorar processos produtivos (de forma a melhorar seus produtos e reduzir custos), apostando, ao mesmo tempo, em sistemas de decoração sofisticados que ajudem a criar um grande apelo visual. De fato, seguindo uma tendência geral da indústria de embalagens, as garrafas de vidro estão mais leves do que nunca (Rowan, 2001; Interpack, 2002). Fabricantes de embalagens de vidro também têm se beneficiado pelos preços relativamente estáveis (em nível internacional) da matéria-prima em anos recentes (Mintel, 2001b) ${ }^{15}$.

\footnotetext{
${ }^{14}$ Martins (1999) classifica a reciclagem pós-consumo em dois tipos: reciclagem em ciclo fechado, em que há, na teoira, um reaproveitamento ilimitado dos materiais, e a reciclagem em ciclo aberto, onde um material feito a partir de matéria-prima virgem é transformado em outro produto que não pode ser reciclado novamente (trata-se de uma extensão do ciclo de vida, mas por tempo limitado). Alumínio, aço e vidro são materiais que se encaixam no primeiro tipo de reciclagem. PET e PEN encontram-se no segundo grupo.

${ }^{15}$ No Brasil, essa vantagem se potencializou com a instabilidade cambial dos últimos anos, que afeta mais fortemente os materiais concorrentes (as resinas plásticas, o aço e o alumínio têm cotação em dólar, pois são matérias-primas negociadas nas bolsas de commodities). Já o vidro sofre impacto
} 
O vidro, além de ser 100\% reciclável (um quilo de cacos de vidro pode ser transformado em uma embalagem nova com o mesmo peso), gera economia de energia ao ser reaproveitado como insumo. Para cada 10\% de matéria-prima reciclada utilizada na confecção de novos recipientes de vidro, uma economia de energia da ordem de 2 a 3 por cento pode ser obtida (GPI, sem data). O valor hoje pago no Brasil por quilo de caco de vidro branco, limpo e beneficiado, é de R\$ 0,13 em média (Abividro, 2003).

1.3.3.2 - Metálicas: Mundialmente, os fabricantes de latas (de aço e de alumínio), a exemplo das vidrarias, procuram reduzir seus custos afinando a espessura das paredes, o que diminui o peso das embalagens (Mintel, 2002b). Porém, nem os avanços das tecnologias de impressão, que hoje permitem reprodução de imagens com alta qualidade, nem a viabilidade comercial das latas com formatos diferenciados (Interpack, 2002) têm garantido o êxito das embalagens metálicas para agregar valor no mercado de cervejas. Esse tipo de embalagem acaba se destinando aos canais onde preço é mais importante (Mintel, 2001a). Por outro lado, as tecnologias de impressão digital e de rotulagem que permitem produzir edições especiais com boa relação custo-benefício podem criar um nicho de mercado no qual as latas podem avançar (Interpack, 2002).

Alumínio e aço (ambos materiais 100\% recicláveis) têm, contudo, grandes diferenças entre si, embora os consumidores finais talvez não as percebam. O valor de venda da sucata de alumínio supera em muito o do aço (paga-se, pelo quilo de alumínio, quase $\mathrm{R} \$ 3,00$ em média, contra $\mathrm{R} \$ 0,35$ a $\mathrm{R} \$ 0,40$ pelo quilo do aço. $\mathrm{O}$ alto valor pago pela sucata do alumínio estimula os “catadores” a recolher o material para reciclagem (Calderoni, 1997; Wells, 2000), o que resulta num elevado índice de recuperação do material. O metal concorrente, por sua vez, tem se utilizado de subsídios, pagos pela CSN - Companhia Siderúrgica Nacional (empresa que fornece $100 \%$ das folhas de flandres para os convertedores que operam no mercado brasileiro), para elevar os seus índices de coleta e reciclagem, e hoje já consegue

parcial dessas alterações no valor da moeda, pois apenas um de seus insumos principais, a barrilha, é cotado em dólares. 
reciclar cerca de 70\% das latas de bebidas produzidas (EmbalagemMarca, 2003c). Quando o alumínio reciclado é usado na produção de novas latas, a economia de energia pode chegar a 95\%. Já com o aço, essa redução fica em torno de $74 \%$ (Calderoni, 1997). Para as cervejarias, as diferenças também existem. A lata de aço, mais barata que a de alumínio, é também menos brilhante e quase duas vezes mais pesada (EmbalagemMarca, 2003c).

1.3.3.3 - PEN e PET: A mídia especializada tem anunciado testes de mercado com cerveja acondicionada em garrafas plásticas desde meados da década de $1990^{16}$ (Packaging Technology \& Engineering, 1998; Food Engineering, 2000; Packaging Digest, 2000), mas a participação deste material no mercado de cervejas ainda é desprezível. Hoje tecnicamente viáveis, as garrafas de PET e PEN para cerveja podem representar uma séria ameaça às embalagens de vidro e às metálicas. Problemas como baixas barreiras de oxigênio e a impossibilidade de enchimento a quente já não existem (Weggeman, 2001; Interpack, 2002; Pack Report, 2002), mas o custo ainda é um obstáculo - tanto a garrafa de PET quanto a de PEN são mais caras que as demais alternativas de embalagem para cerveja (EmbalagemMarca, 2003a; Toleken, 1999; Zoltak, 2001).

O fato de terem sido feitas muitas tentativas para lançar cervejas em garrafas de plástico deve funcionar como um alerta para a indústria do vidro e a de embalagens metálicas, pois demonstra que as cervejarias estão buscando alternativas. Acredita-se que as garrafas plásticas podem roubar parte considerável do mercado desses materiais nos próximos anos (Weggeman, 2000; Zoltak, 2001), mas é improvável que essas garrafas consigam transmitir uma imagem de qualidade superior (Mintel, 2002).

Apesar de a indústria do plástico afirmar que a reciclagem de tais embalagens não é um problema (Packaging Digest, 2000; EmbalagemMarca, 2003a) a reciclagem do PET e do PEN usado em garrafas para cerveja ainda não é

\footnotetext{
${ }^{16}$ Em 1996, a australiana Carlton \& United Breweries Ltd., dona da marca Fosetr's lançou uma de suas linhas em garrafas de PET. A empresa afirma ter sido a primeira cervejaria no mundo a usar esse tipo de embalagem.
} 
comercialmente viável (Mintel, 2002), fato agravado pela existência de processos alternativos de fabricação das garrafas, disponibilizados por diferentes fornecedores, que resultam em vasilhames com composições distintas entre si, inviabilizando um processo único de recuperação e reciclagem.

1.3.3.4 - O que pensam as cervejarias: A posição oficial das cervejarias, passada pelo Sindicerv, é a de que o setor pretende debater com todos os segmentos da sociedade para buscar propostas que "viabilizem a reutilização das embalagens de vidro retornável” (Sindicerv, 2003). O sindicato das cervejarias argumenta que se baseia no conceito dos “3 Rs” (Redução, Reutilização e Reciclagem, nessa ordem de prioridade), de forma a diminuir o impacto das embalagens usadas no meio ambiente. O raciocínio é simples: uma garrafa retornável de 600ml tem vida útil média de sete anos, e é reutilizada, em média, quatro vezes por ano (Sindicerv, 2003). Com isso, reduz-se o volume de resíduos gerados na cadeia produtiva da cerveja.

O fato é que, de acordo com cálculos do Sindicerv, a embalagem retornável, na cerveja, reduz o preço final do produto a ser pago pelo consumidor em até $25 \%$, estimulando as vendas. Outro ponto que conta a favor dessa postura é o fato de o Brasil possuir o maior acervo de garrafas retornáveis de vidro em circulação do mundo. O Sindicerv estima em cerca de 5 bilhões de garrafas (de cerveja e de refrigerantes) retornáveis no mercado brasileiro, e lamenta a pressão de supermercados em favor das embalagens descartáveis, que eliminam a necessidade de que se mantenham estoques para embalagens vazias nas lojas.

O setor apóia medidas similares às adotadas em alguns países europeus, como a Alemanha, que possuem regulamentações favoráveis ao uso de garrafas retornáveis para bebidas. Nessa linha, o Sindicerv mostra-se favorável ao projeto de lei que tramita no Congresso nacional que estabelece que um mínimo de 80\% das cervejas vendidas no Brasil sejam acondicionadas em embalagens retornáveis de vidro. 
Por tudo isso, torna-se relevante compreender como as decisões sobre embalagens são tomadas dentro das cervejarias, identificando-se se o comportamento “verde” do consumidor está sendo levado em conta. É possível que, dadas as características intrínsecas de cada material, a inclusão ou não dessa dimensão ecológica na análise possa alterar a decisão final. Isso teria grande impacto na indústria de embalagens.

\section{4 - Metodologia}

Para estudar os tópicos mencionados acima, esta dissertação recorrerá a uma pesquisa exploratória, baseada em estudos de caso. Esse método mostra-se apropriado, segundo Yin (1994: 13), para o tipo de pergunta que este trabalho se propõe a responder:

Em geral, estudos de caso são a estratégia preferida quando questões do tipo "como" e "por que" estão sendo feitas, quando o pesquisador tem pouco controle sobre os eventos e quando o foco é dado a um fenômeno contemporâneo dentro de algum contexto da vida real.

O mesmo Yin sugere que esse método é também adequado para entender processos organizacionais. Após uma revisão bibliográfica sobre os pontos da teoria de marketing em que se baseia o trabalho, serão conduzidas entrevistas em profundidade com profissionais que possuem poder de decisão sobre embalagens nas indústrias de cerveja que operam no Brasil.

De acordo com Marshall e Rossman (1995), as entrevistas em profundidade, consideradas por eles um dos métodos primários de coleta de dados, trazem o benefício de permitir uma rápida reunião de grande volume de informações. Yin (1994) recomenda que, nos estudos de caso, as entrevistas sejam não-estruturadas. É seguindo uma recomendação de Marshall e Rossman que se optou por entrevistar pessoas-chave na indústria cervejeira. Esses autores apontam como uma das possibilidades de amostragem nos estudos qualitativos o que eles chamam de entrevistas com a "elite”, onde se coloca o foco em pessoas consideradas influentes e 
proeminentes na área de estudo, e/ou bem informadas sobre o tema pesquisado. Todas essas recomendações metodológicas foram seguidas neste trabalho.

Maxwell (1996) também ressalta uma vantagem do estudo qualitativo, relacionada com a amostragem, que pesou na escolha do método dessa dissertação. Segundo ele, as amostras nesse tipo de estudo não devem ser aleatórias, probabilísticas ou de conveniência. Esse autor defende que as amostras sejam escolhidas com um propósito, segundo uma seleção criteriosa. A amostragem em estudos qualitativos, prossegue Maxwell, é uma escolha estratégica para investigar o fenômeno escolhido.

Segundo Miles e Huberman (1994), a opção por uma metodologia envolve, invariavelmente, alguns trade-offs. Neste estudo decidiu-se buscar uma quantidade maior de informações num setor específico, mesmo sabendo-se que os dados coletados não poderiam ser extrapolados para outras indústria. Justifica-se essa escolha com o argumento de que, dados os objetivos da pesquisa, seria fundamental mapear com a maior profundidade possível quais os fatores que afetam as decisões sobre embalagens numa indústria de bens de consumo, de forma a identificar se a dimensão ecológica está presente no dia-a-dia das empresas. Recorrendo a entrevistas em profundidade com representantes de uma única indústria, julgou-se que seria possível levantar dados mais detalhados que ajudassem a responder a pergunta de pesquisa.

Como maior limitação na parte metodológica dessa dissertação o autor reconhece a ausência de métodos alternativos de coleta de dados, processo conhecido como "triangulação", e visto por diversos autores como sendo importante para elevar o nível de validade das conclusões, já que as fraquezas de um método podem ser compensadas pelos pontos fortes de outro (Marshall \& Rossman, 1995; Maxwell, 1996; Stewart, 1998). Nas palavras de Stewart,

Em todas as formas de pesquisa qualitativa (...) o uso de múltiplos métodos de coleta de dados - ou triangulação - é uma tática importante a serviço da veracidade. (p. 28) 
Para tentar minimizar esse problema, as informações oficiais das empresas envolvidas no estudo sobre suas políticas ambientais, disponíveis na Internet, foram analisadas e contrastadas com as respostas obtidas nas entrevistas.

1.4.1 - Participantes do estudo: Escolheu-se entrevistar as pessoas que compõem o núcleo de tomada de decisões sobre embalagens nas principais cervejarias que operam no Brasil.

O autor realizou entrevistas com representantes da AmBev (dona de marcas como Antarctica, Brahma, Bohemia, Skol, Original, Serramalte e Kronenbier), da Molson (proprietária da Kaiser, da Bavaria e da Heineken no Brasil) e da Schincariol (proprietária das marcas Nova Schin, Glacial e Primus), empresas que, juntas, detêm aproximadamente $90 \%$ do mercado.

Dados do instituto de pesquisas AC Nielsen divulgados em junho de 2003 indicam que as marcas líderes em participação no mercado brasileiro de cervejas são a Skol, com 32\%, seguida pela Brahma, com 20,8\%, pela Antarctica e pela Kaiser, ambas com $9,2 \%$ e pela Schincariol ${ }^{17}$, com $8,6 \%$.

1.4.2 - Instrumento de coleta de dados: Nas entrevistas (não estruturadas), que foram conduzidas pessoalmente, utilizou-se um roteiro (Anexo 1) que ajudasse o entrevistador a cobrir todos os pontos importantes para a pesquisa. As conversas foram gravadas e depois transcritas para análise. Essa preocupação com a manutenção de registros segue uma recomendação de Yin (1994), e visa a dar maior confiabilidade à pesquisa ao permitir que terceiros possam analisar os procedimentos seguidos durante o estudo. As respostas foram, posteriormente, agrupadas por temas, e enviadas aos entrevistados para que estes verificassem se não havia mal entendidos ou se havia alguma informação a suprimir ou adicionar.

\footnotetext{
${ }^{17}$ No final de agosto de 2003, a Schincariol rebatizou sua marca principal, que tinha o mesmo nome da empresa, como Nova Schin.
} 
Durante as entrevistas, conduzidas nos escritórios dos entrevistados, não foram formuladas, em um primeiro momento, perguntas que abordassem diretamente temas como meio ambiente e comportamento "verde" do consumidor, para que não se influenciassem as respostas. Os respondentes foram induzidos a falar mais amplamente a respeito de como se dá o processo decisório sobre embalagens na empresa em que trabalham, e quais são os fatores considerados nas decisões. Apenas depois disso é que foram feitas perguntas mais específicas sobre reciclagem, meio ambiente e sustentabilidade. 


\section{CAPÍTULO 2: FUNDAMENTAÇÃO TEÓRICA}

O que esta dissertação pretende responder é se as cervejarias que operam no Brasil estão considerando em seus planejamentos um possível comportamento “verde” do consumidor, motivado por um contexto em que o volume de informações sobre a questão da proteção ambiental ganha destaque, como foi colocado no capítulo anterior.

Acredita-se que, se de fato o discurso sobre a necessidade de se achar uma solução para reduzir o volume de embalagens descartadas no meio natural passar a fazer parte do dia-a-dia do consumidor, haverá uma possibilidade de que este busque alternativas de embalagens que sejam ecologicamente “mais amigáveis”. No caso de isso ocorrer, aquelas empresas que posicionarem seus produtos para atender a essa demanda terão maior probabilidade de satisfazer seus clientes, o que pode resultar em obtenção de vantagem competitiva.

Antes de se apresentarem os estudos de caso, entretanto, é fundamental que se expliquem alguns conceitos que permearão a discussão, e que são de extrema relevância para que se responda a pergunta de pesquisa.

\section{1 - Marketing "Verde”}

A preocupação das sociedades modernas com a preservação do meio ambiente, segundo Peattie (1992), pode ser dividida em três momentos. O primeiro ocorreu no início dos anos 1970, quando começaram a surgir dúvidas com relação ao futuro ambiental do planeta, muito influenciadas por discussões à época em voga a respeito do impacto do crescimento populacional sobre recursos naturais limitados e não renováveis. Alguns fatos marcaram esse período. Em 1971, uma organização chamada Friends of the Earth (Amigos da Terra) jogou cerca de 1500 garrafas descartáveis na porta da fabricante de bebidas Cadbury Schweppes, no Reino Unido, 
para pressionar a empresa a utilizar vasilhames retornáveis. Em 1972, o chamado Clube de Roma publicou "Os limites ao crescimento", documento que alertava para o perigo que o crescimento do consumo poderia representar para o meio natural. De acordo com esse trabalho, se os padrões de crescimento e de consumo se mantivessem inalterados, os recursos naturais da Terra se esgotariam em 100 anos. Ainda em 1972 surgiu o primeiro partido verde do mundo, na Nova Zelândia. Nesse mesmo ano, no Reino Unido, ativistas protestavam contra o uso de peles de animais pela indústria da moda.

O segundo momento apontado por Peattie vai de meados da década de 1970 até meados da década de 1980, e caracteriza-se pelo arrefecimento dos ímpetos ambientalistas, em função da não-concretização das previsões catastróficas contidas em “Os limites ao crescimento”. Mesmo tendo diminuído as pressões ambientalistas, entretanto, o assunto não morreu. Continuaram a surgir alertas que apontavam para um possível colapso ambiental, caso persistissem os padrões de consumo vigentes à época.

No final da década de 1980, acidentes ambientais graves, como o do vazamento nuclear em Chernobyl e o vazamento de gás venenoso em uma planta da Union Carbide no Bhopal, trouxeram a questão novamente para o primeiro plano, iniciando o que Peattie preferiu chamar de terceiro momento. Nessa época, recrudesceu a preocupação com o desgaste do meio ambiente, a mídia passou a se interessar mais pelo assunto e importantes agências ambientais e grupos de pressão se organizaram. Em 1987, foi publicado pela Comissão Mundial do Ambiente e do Desenvolvimento, das Nações Unidas, um relatório que discutia estratégias de desenvolvimento sustentável, intitulado “O nosso futuro comum” (WCED, 1987) também conhecido como Brundtland Report, pelo fato de a comissão ter sido presidida pelo então primeiro ministro norueguês Gro Harlem Brundtland -, texto considerado o marco inicial da preocupação de organismos multilaterais com o tema.

Similarmente, para Kalafatis et al. (1999) a evolução da preocupação com o meio ambiente se deu em etapas. Porém, esses autores usam uma divisão temporal um pouco diferente da adotada por Peattie, e têm uma visão diversa sobre como o processo evoluiu. Para esses acadêmicos, pode-se falar que o "despertar" da 
consciência ambiental ocorreu nos anos 1960. Na década seguinte, foi o momento em que se começou a "agir” com mais contundência. Nos anos 1980 passou-se a se “responsabilizar” os agentes que não respeitavam os recursos naturais. Na última década do século $\mathrm{XX}$, os autores falam no surgimento de uma era de "poder dos mercados”, em que os consumidores se tornaram mais conscientes da fragilidade do meio natural, abrindo espaço para produtos ambientalmente melhores.

Marketing “verde”, conseqüentemente, é uma resposta a essas preocupações com o meio ambiente e com a qualidade de vida, decorrente justamente da utilização indiscriminada de recursos naturais não-renováveis, da sempre iminente crise ambiental que se anuncia desde a década de 1970 e da pressão de grupos organizados sobre as organizações em geral para que essas melhorassem o seu desempenho ambiental. Uma definição concisa - e precisa - do que é marketing “verde” é dada por Peattie (1992), que o classifica como sendo a priorização de aspectos ambientais nas decisões de marketing. Trata-se, em outras palavras, de olhar a teoria de marketing com o objetivo de direcionar as ações das empresas para que haja a melhor utilização possível dos recursos naturais. Conforme o próprio Peattie (1992: 11) explica, o marketing “verde” é o “processo gerencial responsável por identificar, antecipar e satisfazer as exigências dos consumidores e da sociedade de uma forma rentável e sustentável”. Esse é um dos conceitos centrais desta dissertação.

É verdade que, dada a recorrência com que o tema da preservação ambiental tem sido debatido nas sociedades industriais, a dimensão "verde” já faz parte do planejamento de marketing de grande parte das empresas (ao menos nas ações de comunicação), como demonstrou a pesquisa resumida no Quadro 1.1 apresentado anteriormente. O chamado marketing "verde", no entanto, é mais do que a simples consideração dessa variável. Trata-se da proeminência dela no planejamento de marketing.

Sob essa perspectiva, os impactos das práticas empresariais sobre o meio ambiente devem ser cuidadosamente examinados pelas organizações que consideram a possibilidade de adotar uma estratégia de posicionamento baseada em questões ecológicas. Ademais, em função do crescimento em relevância que o tema tem tido, 
pressões sociais e legais podem tornar improvável o sucesso de iniciativas que não observarem um nível mínimo de responsabilidade ambiental (Peattie, 2001).

O problema é que esse "nível mínimo" parece ser cada vez mais alto, e equívocos na sua interpretação podem ser perigosos para a rentabilidade dos negócios (Peattie, 2001). Há autores, entretanto, como Handelman e Arnold (1999), que sugerem que ultrapassar esse limite de tolerância dos consumidores, superando expectativas, pode valer a pena. $\mathrm{O}$ argumento utilizado por esses acadêmicos é o de que, ao fazer isso, as empresas colocam os concorrentes em situação comparativamente desfavorável, numa clara alusão ao fato de que o marketing "verde” pode assumir grande importância na busca por vantagem competitiva. Nas palavras de Handelman e Arnold (1999: 43):

Há um nível mínimo de ações institucionais que se considera aceitável (...) Um competidor pode aumentar este nível mínimo tomando ações institucionais que sejam mais significativas do que as dos seus concorrentes.

Na mesma linha, Coddington (1993: 1-2) aponta para os benefícios potenciais que podem advir da superação dos limites mínimos tolerados pela legislação e pelos consumidores.

[Fazer o mínimo] é legalmente adequado, mas estrategicamente atrasado. Administradores de visão estão identificando e aproveitando novas oportunidades de negócios relacionadas com o ambiente que vão da prevenção da poluição e [da adoção de] tecnologias mais eficientes à educação ambiental e à promoção de produtos "verdes".

Porém, apesar das evidências que mostram o valor de ações de marketing com uma dimensão social, algumas empresas temem ainda potenciais trade-offs com ações estratégicas orientadas economicamente (Handelman \& Arnold, 1999). Porter e Van der Linde (1995), por sua vez, sugerem que a aceitação da idéia de que tais trade-offs existem pode representar uma oportunidade perdida pelas empresas. Esses autores argumentam que desperdício, sob qualquer forma, reflete ineficiência, opinião compartilhada pela Organização das Nações Unidas (ONU, 2001) ${ }^{18}$, e que as

\footnotetext{
${ }^{18}$ Estimativas do DEFRA - Department for Environment, Food, and Rural Affairs [Departamento para o Ambiente, Alimentos e Questões Rurais] do Reino Unido, por exemplo, são de que o custo
} 
companhias podem ficar mais competitivas eliminando tais ineficiências através da inovação contínua. Para eles, as exigências para que se obedeçam padrões de comportamento ambientalmente rigorosos, sejam elas impostas por regulamentações, sejam derivadas da pressão imposta pelos próprios consumidores, podem, à primeira vista, parecer uma fonte adicional de custos que reduz a eficiência econômica dos negócios. Contudo, a busca por soluções estimularia a criatividade, levando a inovações que, no longo prazo, aumentariam a eficiência da empresa.

Esta hipótese é desafiada por Hitchens et al. (2000), cuja posição é a de que, apesar de não haver nenhum trade-off significativo entre competitividade e proteção ambiental, ganhos sistemáticos com o desenvolvimento de novos produtos “verdes” são improváveis. Esses acadêmicos dizem ser difícil acreditar que regulamentações ambientais rigorosas possam gerar inovação, mas reconhecem que é provável que, num futuro próximo, o desempenho ambiental de uma empresa torne-se vital para o seu desempenho econômico. Conseqüentemente, em defesa do marketing "verde” pode-se argumentar que tanto a dimensão social como os parâmetros econômicos devem ser levados em conta no planejamento das empresas, sem necessariamente caracterizarem-se como metas contraditórias.

A discussão sobre se uma postura "mais verde" pode ou não garantir um desempenho melhor às empresas deveria, de acordo com Peattie (1999, 2001), ser conduzida em um nível muito mais profundo, contudo. Esse autor mostrou que há uma incompatibilidade entre os conceitos de sustentabilidade e do marketing convencional, e insiste em que haja uma revisão da teoria de marketing. Para ele, as companhias com atuação ambiental hoje tendem a desenvolver estratégias que enfatizam os aspectos ecológicos de algumas de suas atividades - geralmente o desenvolvimento de novos produtos e a comunicação - sem se dedicar a desenvolver atividades plenamente sustentáveis.

médio do desperdício de matérias-primas, água e outros recursos é dez vezes maior do que o custo de disposição adequada do lixo (DEFRA, 2001b). 


\section{2 - Desenvolvimento Sustentável}

O termo “desenvolvimento sustentável” ganhou força após o Earth Summit Rio 1992, encontro realizado pela Organização das Nações Unidas no Rio de Janeiro para discutir a questão ambiental e o desenvolvimento econômico das nações (Levy, 2000). A definição mais freqüentemente citada desse conceito é a que aparece no relatório “Nosso Futuro Comum”, o Brundtland Report, que diz que

Desenvolvimento sustentável é o desenvolvimento que atende as necessidades das gerações atuais sem comprometer a capacidade de as gerações futuras atenderem suas próprias necessidades (WECD, 1987).

Porém, a aparente simplicidade do tema acabou gerando uma profusão de definições, muitas vezes adaptadas a interesses específicos. Por isso, apesar da constância com que o assunto aparece em discussões nas mais variadas esferas, de fóruns empresariais a debates sobre políticas ambientais, pouco se avançou, na prática, em direção à sustentabilidade (Levy, 2000). Essa opinião é compartilhada por Peattie (1999: 132), que observou que “o padrão global de atividade econômica não parece dramaticamente diferente daquele identificado como insustentável no Brundtland Report”, apesar de algumas mudanças em produtos e processos produtivos terem sido introduzidas desde então ${ }^{19}$.

Na América Latina, alguns anos depois, foi a vez da CEPAL e do PNUMA, órgãos das Nações Unidas, constatarem que os avanços rumo ao desenvolvimento sustentável haviam sido pífios. As causas para isso, na avaliação das duas entidades, não se restringem ao baixo crescimento econômico da região, considerado por elas insuficiente para promover a sustentabilidade:

É evidente que os padrões de produção e consumo que imperam carecem de viabilidade social, econômica e ambiental (CEPAL \& PNUMA, 2002: 13)

\footnotetext{
${ }^{19}$ Essa visão foi confirmada por estudo elaborado pelo Programa Ambiental das Nações Unidas, que constatou que a maior parte das empresas ao redor do mundo continuam a gerir seus negócios de forma não-sustentável (EUWID, 2002).
} 
De qualquer maneira, a recorrência com o tópico do desenvolvimento sustentável tem aparecido na mídia na maioria dos mercados ocidentais parece ter elevado a conscientização dos consumidores sobre os efeitos que produção e consumo podem ter no ambiente (Wagner, 1997). Embora o impacto desta “consciência ambiental” nos hábitos de compra das pessoas ainda seja incerto, como demonstraram algumas incursões comerciais no campo dos produtos "verdes" que resultaram em níveis frustrantes de vendas (Bei \& Simpson, 1995; Kalafatis et al., 1999), ninguém parece questionar sua importância para os negócios (Peattie, 2001; Ottman, 1998).

Uma das razões para isso é que o descontentamento crescente de grupos da sociedade com companhias que têm baixo desempenho social (percebido) tem gerado ataques, por parte de alguns ativistas, a marcas conhecidas (Klein, 2000). Atitudes negativas do consumidor podem trazer danos consideráveis à imagem das marcas, ameaçando a rentabilidade das empresas no longo prazo (Aaker, 1996; Kapferer, 1997). Porém, como mostrado por Sen et al. (2001), os problemas da associação de uma marca com um “mau comportamento” ambiental também podem ter efeitos imediatos, se traduzidos na forma de boicotes cujo intuito é o de pressionar as empresas a adotarem uma atitude “mais responsável”.

Por outro lado, tem-se discutido que consumidores atentos à questão ambiental podem representar boas oportunidades para empresas que desenvolverem produtos e serviços apoiados no mote da ecologia (ETBPB, 2000). Isso indica que o marketing “verde” é um conceito muito complexo para ser levado apenas no nível tático, e que deveria ser integrado em todas as áreas da organização, permeando a empresa inteira, de forma a gerar benefícios no longo prazo (Polonsky \& Rosenberger III, 2001; Peattie, 2001). Conseqüentemente, as companhias deveriam tentar integrar critérios não-econômicos no seu processo de tomada de decisões estratégicas (Handelman e Arnold, 1999). Isto pode requerer investimentos a longo prazo, o que por sua vez pode contrariar o interesse de acionistas que se beneficiam da valorização das ações no curto prazo (Shleifer \& Vishny, 1997).

Conforme acredita Juchem (1995), entretanto, o lucro - que, em última instância, é o objetivo das corporações - só pode ser alcançado se a empresa estiver 
apoiada num tripé de responsabilidades: econômica, social e ambiental. Para Harris e Goodwin (2001), aliás, são esses os três aspectos fundamentais do desenvolvimento sustentável.

Porém, o risco de comunicar ao mercado um posicionamento com apelos ambientais sem adotar uma postura efetivamente "verde" - ou, usando o jargão de Peattie (1999, 2001), não adotar uma “estratégia de marketing sustentável” - é que uma empresa pode ser "punida” pelos consumidores e pela mídia, que podem considerar a empresa apenas oportunista.

Para orientar as corporações a agir de forma ambientalmente responsável, foi publicada em 1991, pela Câmara de Comércio Internacional, a Carta de Roterdã, apontada por Juchem (1995) como sendo o documento que define as diretrizes ambientais, em âmbito internacional, a ser seguidas pelas empresas. Os principais pontos desse documento, enumerados pelo autor, são:

1) O gerenciamento ambiental precisa ser considerado uma prioridade nas políticas corporativas;

2) Políticas, programas e práticas que visem ao desenvolvimento sustentável devem ser integrados em cada atividade da empresa;

3) As empresas devem investir para o contínuo aprimoramento dessas políticas, programas e práticas ambientais, buscando critérios que sejam uniformes em todos os países;

4) As corporações precisam oferecer treinamento e investir na educação dos seus empregados, com o intuito de que esses estejam motivados a conduzir suas atividades de forma ambientalmente responsável;

5) Os impactos ambientais de todos os investimentos devem ser considerados a priori;

6) O desenvolvimento de produtos e serviços cada vez mais "verdes” deve ser a meta das empresas;

7) Cabe às empresas informar e orientar os usuários de seus produtos e serviços para garantir a segurança do ambiente e das pessoas;

8) As corporações devem adaptar ou projetar suas instalações para otimizar a utilização de recursos e energia, e minimizar a emissão de resíduos; 
9) Investimentos em pesquisas que levem a menores impactos ambientais da produção não podem ser ignorados pelas empresas;

10)Além disso, cabe aos gestores dos negócios trabalhar de forma a prevenir a degradação ambiental;

11)Fornecedores e clientes devem ser encorajados a agir de forma igualmente responsável em relação ao meio ambiente;

12) Nas situações em que há riscos ambientais significativos, as corporações precisam manter planos de emergência que considerem os impactos além dos limites da empresa;

13)Incentiva-se também a transferência de tecnologias que ajudem a minimizar impactos ambientais;

14)Recomenda-se ainda a participação em programas e políticas (públicas ou privadas) que visem à difusão de informações e à educação ambiental;

15) As empresas devem manter-se abertas ao diálogo com os stakeholders; e

16)Finalmente, às empresas sugere-se a adoção de auditorias ambientais, que permitam a acionistas, empregados, governo e demais grupos de interesse acompanhar o eco-desempenho corporativo.

Há que se perguntar, então, por que (se tão importante para empresas e consumidores) essa crescente preocupação com o meio ambiente não tem sido capaz de levar a um desenvolvimento mais sustentável (como notado por Peattie, 2001), nem de alavancar as vendas de produtos ecologicamente corretos (a exemplo do que relataram Bei e Simpson, 1995, e Kalafatis et al., 1999). A explicação para este paradoxo aparente pode advir de quatro fatores principais, interligados e complementares. Os dois primeiros são apresentados por Kalafatis et al. (1999). O terceiro pode ser extraído dos trabalhos de Peattie (1999, 2001). O quarto surge da análise do modelo cognitivo elaborado por Wagner (1997).

2.2.1 - Restrições financeiras: O primeiro desses fatores que pode explicar por que, apesar de os níveis de conscientização dos consumidores com relação ao impacto ambiental dos seus hábitos de consumo terem aumentado - de forma acentuada até o início dos anos 1990, quando parecem ter atingido um patamar -, as 
vendas de produtos verdes não terem crescido no mesmo ritmo refere-se à opção dos consumidores por não comprar um produto ambientalmente melhor (mesmo sabendo das conseqüências dessa decisão) em função de restrições financeiras, já que, como constataram Bei e Simpson (1995), em geral os produtos "verdes" chegam ao mercado com um preço-prêmio.

2.2.2 - A complexidade da questão: O segundo fator diz respeito ao desconhecimento, por parte dos consumidores, de quais os verdadeiros impactos de cada uma de suas ações sobre o meio natural. O resultado concreto é que determinados comportamentos podem ser mais influenciados pela preocupação com a preservação do meio ambiente do que outros. Isso significa que o consumidor pode não considerar que alguns de seus hábitos de consumo têm vínculo estreito com a degradação ambiental, ou que pode haver fatores - além das restrições financeiras que inibam a propensão a comprar produtos mais “verdes”.

2.2.3 - A definição do que seja "verde”: O terceiro fator relaciona-se com a idéia de como o termo "ecologicamente adequado" foi incorporado à prática de negócios. Ocorre que a expressão “verde” nem sempre é compreendida como sinônimo de "sustentável”, sendo na maioria das vezes vista apenas como “ecologicamente melhor” (ou “ambientalmente mais amigável”) do que as demais opções disponíveis no mercado (Peattie, 2001). Até o momento, porém, isso não parece ter sido suficiente para convencer os consumidores a mudar seus hábitos.

Além disso, é provável que empresas que se divulguem como “verdes” sejam monitoradas de perto pela mídia e pelo público em geral, sempre ansiosos por denunciar qualquer deslize que venha a ser cometido - mesmo quando o ecodesempenho global de tais empresas é superior ao de seus competidores diretos (Peattie, 2001). Como conseqüência, argumenta o mesmo Peattie, os consumidores parecem estar cada vez mais imunes a apelos ecológicos, quando os consideram mera retórica. Por isso, continua o autor, empresas que adotam estratégias de comunicação baseadas em apelos ecológicos mas que mantêm práticas que 
contradizem esse posicionamento acabam por contribuir para o quadro de descrença geral com relação a práticas de negócios sustentáveis.

Há quem vá ainda mais longe, argumentando que a tão proclamada sustentabilidade é uma meta utópica. O antagonismo entre a lógica de se comprar cada vez mais - a base do consumismo nas sociedades capitalistas - e a responsabilidade social das empresas tem sido realçado por textos acadêmicos desde a década de 1970 (Brien et al., 1972), e tem recebido atenção crescente desde então (para uma discussão sobre as contradições entre a proteção do consumidor considerada uma das responsáveis pelo reforço da lógica do consumismo - e a proteção ambiental, que usa como exemplo a legislação na União Européia, recomenda-se a leitura de Tonner, 2000). No mundo dos negócios, entretanto, as vozes que pedem uma mudança mais radical no comportamento corporativo em direção ao desenvolvimento sustentável ainda são minoria (Murray, 1999; Peattie, 1999, 2001).

Mainieri et al. (1997), por exemplo, ao investigar o impacto da preocupação ambiental no "consumerismo verde" (que os autores utilizam como sinônimo de hábitos de compra “mais verdes”), não tocam na questão da sustentabilidade (conforme entendida no Brundtland Report), e definem como “verdes” aqueles produtos que têm um desempenho ambiental melhor quando comparados aos bens substitutos. Esta perspectiva relativística é consoante com a lógica de um consumo crescente, independentemente dos efeitos que isso acarreta ao meio ambiente (o que, evidentemente, não pode ser classificado como sustentável) e, de alguma maneira, justifica a constatação de que produtos, processos produtivos e os próprios hábitos de consumo nas sociedades ocidentais não tenham sido alterados drasticamente. Afinal, seguindo a lógica “verde” defendida por Manieri et al. (1997), basta ter um produto ou processo ecologicamente menos danoso do que as alternativas concorrentes para que se tenha um produto "verde".

O paradoxo entre a importância atribuída à questão ambiental por empresas e consumidores e o baixo desempenho comercial de alguns produtos "verdes" pode ser, neste caso, o resultado da existência de múltiplos entendimentos do que seja “verde”. A conseqüência disso é que há empresas que têm adotado uma abordagem 
simplista e rasa do assunto, insuficiente para caminhar na direção do desenvolvimento sustentável (Murray, 1999; Peattie, 1999, 2001). Da parte do consumidor, a percepção as iniciativas “verdes” das empresas não vão muito além da retórica os tem tornado "imunes” a tais apelos (Bei \& Simpson, 1995; Kalafatis et al., 1999; Peattie, 1999).

2.2.4 - Diferenças entre Intenção e Ação: A quarta possível explicação para o fato de as vendas de produtos "verdes" não terem acompanhado o grau de preocupação com o meio ambiente repousa na discrepância entre as intenções declaradas pelo consumidor em comprar produtos mais ecológicos e o seu comportamento efetivo (Wagner, 1997). Há várias possíveis razões para esta incongruência. Para começar com a mais simples delas, intenções auto-reportadas estão sujeitas a pressões sociais (Kalafatis et al., 1999) que podem levar as pessoas a dizer que pretendem adquirir produtos mais “verdes” mesmo quando este não é o caso - e o bom senso indica que atitudes positivas para com o ambiente têm boa probabilidade de serem aprovadas por outras pessoas. Todavia, a realidade é bem mais complexa que isso.

Atitudes favoráveis ao meio-ambiente parecem ser uma condição necessária, mas não suficiente, para ativar um comportamento "verde” de compra (Wagner, 1997). Os consumidores parecem estar propensos a materializar essas atitudes em compras de produtos "verdes" dependendo da magnitude dos trade-offs envolvidos (tais como um preço prêmio ou a maior dificuldade em encontrar os produtos cujo impacto ambiental é menor), pois podem não estar dispostos a sacrificar seu conforto, a conveniência, em nome de um “mundo melhor” (Peattie, 1999, 2001). A uma conclusão semelhante chegaram Mainieri et al. (1997: 202), ao especularem sobre as causas da discrepância entre intenções e ações:

Razões possíveis para a diferença entre o consumerismo pró-ambiental e as atitudes dos respondentes podem incluir a disponibilidade inadequada, rótulos e comercialização inadequados daqueles produtos ambientalmente benéficos, assim como preços mais altos em alguns casos. 
Além disso, devido à avalanche de apelos “verdes” no mercado, e ao ceticismo crescente em relação à confiabilidade desses apelos, como exposto na seção anterior, sacrificar-se parece não ser muito atraente aos olhos dos consumidores.

Ainda assim, a consideração de aspectos ambientais e econômicos no desenvolvimento de novos produtos - ou a busca pela eco-eficiência - passou a ser vista como um instrumento de grande valia para alterar essa realidade (ONU, 2001). Conforme Hindle e White (1999, apud Levy, 2000) ${ }^{20}$ colocam, o desenvolvimento sustentável - entendido pelos autores como a "gestão ambiental na direção da sustentabilidade econômica e tecnicamente viável e socialmente aceita” - é, hoje, o grande desafio das corporações.

Dada a grande aceitação do tema nas mais diferentes esferas, e graças à sua presença cada vez maior em textos acadêmicos e manuais de administração, porém, o desenvolvimento sustentável está no coração de qualquer discussão atual sobre a interação do homem com o meio natural (Levy, 2000). Assim sendo, o primeiro passo que as corporações devem tomar rumo à sustentabilidade é compreender qual o significado que o termo tem para si mesmas. Apenas após ter clareza disso é que se pode pensar em desenhar programas capazes de orientá-las na direção do desenvolvimento sustentável.

Um obstáculo significativo à desejada sustentabildade, entretanto, é apontado por Levy (2000). Segundo esse autor, a realidade dos negócios mostra que os custos da poluição ambiental não são integralmente contabilizados nos cálculos econômicos das empresas, e que, por isso, não estão necessariamente refletidos nos produtos. Ainda não está claro, contudo, como essa questão poderia ser superada (ou mesmo se isso seria possível). Nas colocações de Levy (2000:79):

Enquanto os danos ambientais gerados pelas embalagens são geralmente conhecidos, a definição exata do impacto, tanto em termos ambientais quanto econômicos, que elas têm é imprecisa. Aliás, pode o custo econômico real ser definido com precisão, de forma que os produtos reflitam acuradamente o seu impacto ambiental, ou, em outras palavras, pode esse custo ambiental ser internalizado em termos econômicos?

\footnotetext{
${ }^{20}$ HINDLE, P. e P. WHITE (1999). Managing Towards Sustainability: A Concept in Daily Business. Chimica Oggi, International Journal of Chemistry and Biology, Milan, Italy.
} 
O problema, segundo o raciocínio de Levy (2000), é que nem todos os custos ambientais são fáceis de calcular (obviamente, há também custos que são mensuráveis e cuja contabilização é hoje amplamente aceita, como é o caso do consumo de energia em diferentes estágios do ciclo de vida), o que pode gerar distorções nas comparações de processos alternativos. Autores como Barde e Pearce (1995), por exemplo, indicam ser necessárias técnicas de mensuração que evidenciem o valor de bens como "ar limpo" e "vista bonita”, o que demonstra o grau de dificuldade envolvido na tarefa.

Há, entretanto, um esforço no sentido de traduzir custos ambientais em termos monetários, o que tornaria mais fácil a sua internalização nos custos dos produtos. Com isso, acredita Levy (2000), seria mais fácil analisar o impacto de cada embalagem, e “as forças de mercado determinariam a demanda por produtos que incorporassem totalmente os custos ambientais” (p. 80). É importante que se destaque, no entanto, que existem reações a essa tendência, advindas, de acordo com Barde e Pearce (1995), de três campos distintos:

(a) Ético e filosófico - alguns grupos ambientalistas argumentam que o meio natural não pode ser entendido como um amontoado de bens econômicos, e que, portanto, não pode ser medido como tal;

(b) Político - Há, por parte de alguns governantes, relutância em trazer o tema da preservação ambiental, em sua totalidade, para o centro da discussão, pois isso exporia as debilidades das presentes políticas preservacionistas, e as influências de alguns grupos de interesse sobre elas;

(c) Técnico-metodológico - As dificuldades na aplicação das técnicas acaba inibindo a sua adoção em alguns lugares, e é usada como argumento para tal.

Tais resistências, de acordo com Barde e Pearce (1995), não eliminam a necessidade de que se busquem formas amplamente aceitas de medir custos ambientais, para que se criem parâmetros capazes de orientar as empresas rumo ao desenvolvimento sustentável. A maior barreira a essa padronização ainda é a divergência sobre como mensurar e contabilizar, com rigor, todos os fatos durante a 
vida de uma embalagem, o que leva muitos a sugerir que se trabalhe apenas com “indicadores de sustentabilidade” (Levy, 2000; Smith \& White, 2000). Isso, contudo, não deve mitigar a busca pelo refinamento das metodologias de atribuição de valores monetários aos recursos naturais (May, 1999).

Nesse sentido, há hoje uma série de esforços coordenados com o intuito de explicitar a relação entre meio ambiente e desenvolvimento econômico, questão que precisa ser entendida com maior profundidade.

\footnotetext{
"O debate moderno sobre desenvolvimento sustentável tende a deslocar o foco de crescimento versus meio ambiente para a potencial complementaridade entre crescimento e meio ambiente.

(...)

Na realidade, nenhuma das abordagens parece ser correta.” (Pearce et al., 1992: 21)
}

Isso porque, segundo Pearce et al. (1992), o desenvolvimento sustentável nem é incompatível com o crescimento, e nem o crescimento econômico é capaz de, sozinho, gerar sustentabilidade. O ponto fundamental a ser compreendido é como esse crescimento deve se dar e, para tal, é necessário compreender o valor econômico do ambiente.

De acordo com Goodwin (2001), as empresas precisam prestar contas aos stakeholders de forma transparente, pois essa visibilidade constitui a base da responsabilidade social corporativa. A contabilização de valores ambientais, em termos econômicos, no dia-a-dia das empresas é uma das iniciativas nessa linha.

\section{3 - Contabilidade Ambiental}

Descobrir o "valor da conservação ambiental” tem sido a preocupação de acadêmicos como Barde e Pearce (1995), que sugerem um referencial capaz de orientar a contabilização de custos imputados ao ambiente e de benefícios deste obtidos. Para eles, seria necessário considerar o valor de uso do recurso preservado, os valores indiretos (tais como as funções ecológicas do recurso preservado), os valores de opção (valor do recurso para uso futuro, ainda que não se faça uso dele) e 
o valor de existência (valor intrínseco do recurso em seu estado natural, que emana de sua simples existência - uma "bela vista", por exemplo). Os autores admitem que a mensuração pode ser difícil, por envolver aspectos de julgamento subjetivo, mas insistem que é possível chegar a números confiáveis.

Pearce et al. (1992), por sua vez, enxergam na teoria econômica um campo promissor para que se avance no sentido do desenvolvimento sustentável, que eles acreditam ser um objetivo factível. A argumentação desses acadêmicos é a de que seriam necessárias modificações nos padrões de consumo, mas que ao mesmo tempo se deveria atribuir valor ao meio ambiente e mensurar os custos e benefícios de políticas de prevenção da degradação ambiental.

A economia contribui para o entendimento do que seja desenvolvimento sustentável porque o meio ambiente e a economia necessariamente interagem.

(...)

O desenvolvimento sustentável é viável. Requer uma alteração de ênfase na maneira como o progresso econômico é perseguido. Preocupações ambientais devem ser integradas de forma adequada à política econômica, do nível mais alto (macroeconômico) ao mais baixo (micro-econômico). (Pearce et al., 1992: xiv)

A contabilidade ambiental procura exatamente oferecer um ferramental metodológico para isso, ao propor formas para medir despesas e receitas ambientais que viabilizem a consolidação de um balanço corporativo em que os impactos da produção sobre o meio natural estejam incluídos. Esse corpo metodológico é visto como uma alternativa concreta para superar as limitações da contabilidade tradicional como ferramenta de apoio às organizações que procuram estruturar sua produção de forma sustentável, conforme explicitado em documento produzido pela Organização das Nações Unidas (ONU, 2001: 1).

Têm sido amplamente reconhecidos os limites dos métodos de contabilidade tradicional financeira e analítica, para reflectir os esforços das organizações em direcção à sustentabilidade e para fornecer aos gestores a informação necessária para a tomada de decisões empresariais sustentáveis. Em certa medida, a informação acerca do desempenho ambiental das organizações pode estar disponível mas, nas empresas, assim como nas autoridades públicas, os decisores são raramente capazes de relacionar a informação ambiental com as variáveis económicas e falta-lhes, sobretudo, informação sobre os custos ambientais.

(...) 
Embora existam diferentes definições, a utilização geral da informação da CGA [Contabilidade da Gestão Ambiental] ${ }^{21}$ serve essencialmente para ser utilizada internamente pela empresa nas suas tomadas de decisão.

A tendência, apontada pelas Nações Unidas como iminente, é de que haja uma convergência entre os relatórios ambientais e financeiros que hoje são publicados, e que seja feita a consolidação de ambos num único "relatório de sustentabilidade" (ONU, 2001). Tal perspectiva é confirmada por Levy (2000), que acredita que não se trata de saber se, mas sim quando, isso ocorrerá.

A idéia defendida pela ONU é a de que os custos ambientais não devem ser vistos como custos "à parte”, mas que precisam ser computados dentro de um "sistema integrado de fluxos materiais e monetários que percorrem a empresa”. Por essa visão, qualquer tipo de emissão de resíduo deve ser considerada como um sinal de produção ineficiente. Dessa forma, todos os resíduos emitidos (que o documento da ONU chama de “output não-produto”) devem ser contabilizados para que se calculem os custos ambientais incorridos por uma empresa em seu processo produtivo. Com isso, chegar-se-ía a indicadores que permitiriam medir tais custos em termos econômicos, possibilitando às empresas melhorar a eficiência no uso dos materiais, reduzir o impacto e o custo ambiental e diminuir os gastos com a prevenção da degradação do ambiente. Consoante com essa visão, Juchem (1995: 21) argumenta que as "empresas precisam perseguir a otimização econômica e ambiental, pois ela representa um dos principais caminhos para evitar, reduzir, reciclar, reutilizar ou melhorar o uso de: energia, matéria-prima, insumos, água, solo e embalagens”. Isso implica a busca por tecnologias que visem à melhor utilização de recursos e que reduzam impactos ambientais. Em outras palavras, a empresa deve esforçar-se para trilhar o caminho da eco-eficiência.

May (1999), ao tratar do assunto, justifica a necessidade de que sejam atribuídos valores econômicos aos recursos naturais ao afirmar que

\footnotetext{
${ }^{21}$ De acordo com Juchem (1995: 35), “a gestão ambiental empresarial se restringe a empresas e instituições e pode ser definida como sendo um conjunto de políticas, programas e práticas administrativas e operacionais que levam em conta a saúde e a segurança das pessoas, e a proteção do meio ambiente através da eliminação ou minimização de impactos e danos ambientais decorrentes do planejamento, implantação, operação, ampliação, realocação ou desativação de empreendimentos ou atividades, incluindo-se todas as fases do ciclo de vida do produto.
} 
os conceitos de alocação e expressão de preferências, fundamentais para a teoria econômica neoclássica dominante, não são adequados para avaliar bens cujos preços não são evidenciados no mercado, e cujos usuários, incluindo as gerações futuras, não têm meios de fazer suas preferências serem percebidas. Esses problemas levam a falhas de mercado que resultam na superutilização de recursos naturais e em pressões sobre a capacidade dos ecossistemas naturais de absorverem resíduos. (pp. 16-7)

Visão muito semelhante têm Barde e Pearce (1995: 5), para quem “a razão para que se dediquem tempo e recursos a problemas de valoração [do ambiente] é que eles tendem a ocorrer fora das situações de mercado”, e Pearce et al. (1992: 5-7), que sustentam que

O princípio importante é que recursos e o ambiente desempenham funções econômicas e têm um valor econômico positivo. Tratá-los como se eles tivessem valor zero é criar o sério risco de superutilização do recurso.

Para a ONU, os custos ambientais podem ser divididos em dois grupos básicos: os que têm impacto direto sobre a estrutura de custos das empresas, e os que são “subsidiados” pela sociedade:

Numa perspectiva macroeconômica, o preço das matérias primas escassas, da poluição e da deposição não reflectem o seu verdadeiro valor e os seus custos para a sociedade. Os riscos para a saúde, a remediação dos locais contaminados, etc., são custos ambientais usualmente não suportados pelo poluidor mas pelo público em geral. (ONU, 2001: 10)

Goodwin (2001), por isso, sustenta que a contabilidade ambiental deveria justamente ser o instrumento capaz de “internalizar as externalidades”.

O objetivo da ONU com a publicação de um documento específico sobre contabilidade ambiental, porém, é claramente o de indicar procedimentos que permitam consolidar uma metodologia de mensuração. Nessa linha, sugere que se considerem os custos ambientais que ocorrem dentro da empresa, e que se excluam os custos que tipicamente são divididos com a sociedade. Explicitamente, a ONU atribui aos governos a função de equacionar essa questão, através da cobrança de eco-taxas e da imposição de outros mecanismos regulatórios que internalizem os 
custos ambientais externos às organizações, seguindo o princípio do poluidorpagador, uma linha que também é defendida por May (1999).

Quando, entretanto, há custos externos que são subsidiados pela sociedade ${ }^{22}$, a análise conduzida em termos puramente econômicos pode trazer distorções, por não considerar dimensões intangíveis e de difícil mensuração, como um eventual ganho de imagem em decorrência de investimentos na prevenção da emissão de resíduos, por exemplo. Daí a inadequação da contabilidade tradicional financeira para lidar com a questão ambiental, e a premência para que se alterem os paradigmas contábeis (ONU, 2001: 91).

A opção num contexto de cumprimento da legislação entre estratégias de prevenção e de fim-de-linha de uma empresa irá depender maioritariamente da comparação económica das duas opções. Isto é claro nas instâncias em que a rentabilidade é negativa, ou seja, quando a empresa espera uma perda líquida no seu investimento. Ao contrário de muitas tecnologias de fim-de-linha, os projectos de prevenção da poluição tendem a reduzir os custos operacionais através da redução da produção de resíduos, actividades regulamentadas e responsabilidades relacionadas com a poluição. Adicionalmente, investimentos na prevenção da poluição poderão aumentar os rendimentos através da melhoria do produto e/ou da imagem da empresa. Ao incluir esses benefícios indirectos ou menos tangíveis na análise financeira da empresa, poder-se-á aumentar a rentabilidade estimada da estratégia de prevenção, e poderá ser decisivo na opção entre uma acção de prevenção da poluição e uma opção fim-de-linha.

A necessidade de que se privilegiem aspectos menos tangíveis na consideração de investimentos é, provavelmente, uma das conclusões mais importantes a que chega o relatório da ONU. A preferência por soluções que atuem na prevenção da poluição, em detrimento daquelas que apenas procuram minimizar os seus efeitos, acaba aparecendo como um corolário (ONU, 2001: 10):

As actividades públicas e das empresas na área da gestão ambiental ainda se centram nas tecnologias de fim-de-linha, as quais no curto prazo aparecem como uma solução expedita, mas que no longo prazo levam frequentemente a um maior consumo de materiais e energia, mais despesa em capital e mais horas de trabalho do que se as medidas fossem tomadas na origem da poluição.

\footnotetext{
${ }^{22}$ Nos países da América Latina constatou-se que o princípio do poluidor-pagador não vigora, e que os governos acabam arcando com os custos de coleta e disposição dos resíduos (CEPAL \& PNUMA, 2002)
} 
Isso porque, quando se medem os fluxos de materiais, como recomenda a metodologia da contabilidade ambiental, o custo da produção da emissão de resíduos deve se somar às despesas com a implementação de sistemas de tratamento de poluentes antes que estes sejam comparados com soluções preventivas. Os benefícios (como aumentos de rendimento decorrentes da melhoria da qualidade do produto e ganhos de imagem), apesar de mais difíceis de mensurar, também precisam ser incorporados aos cálculos.

Adicionalmente, Pearce et al. (1992), com base no princípio das preferências de tempo ${ }^{23}$, indicam que soluções preventivas seriam menos atraentes aos olhos dos investidores do que medidas reativas, pois o desencaixe ocorreria em um tempo futuro. Porém, esses autores alertam para outros fatores que devem ser considerados na análise, e que podem alterar essa situação. Primeiro, não se pode ter certeza que o custo futuro de ações reativas seja o mesmo que se estima no momento da análise, em função das incertezas que o tempo impõe. Segundo, porque ações reativas em geral não são consistentes com o desenvolvimento sustentável. Em terceiro lugar, porque os próprios efeitos ambientais possuem um grau intrínseco de incerteza, o que indica que ações preventivas são mais apropriadas. Os autores acreditam que a única situação em que se justificaria a preferência de ações reativas sobre as preventivas é quando se usa o tempo ganho para investir em pesquisas que visem a soluções melhores do que as de que se dispõe no momento da análise.

Ao tomarem suas decisões de acordo com esse arcabouço teórico, as empresas naturalmente caminhariam na direção da eco-eficiência, seja através do redesenho de produtos e processos, seja através de práticas de gestão apoiadas por sistemas de gestão ambiental (ONU, 2001). Indiretamente, tais benefícios são reconhecidos também por (Levy, 2000: 92):

(...) os custos ambientais associados com outras atividades [além da prevenção e do controle da poluição] podem ser bem maiores, e a escolha de matérias-primas, processos produtivos e desenho de produto podem afetá-los de forma significativa.

\footnotetext{
${ }^{23}$ Pelo princípio das preferências de tempo, os agentes econômicos preferem usufruir dos benefícios de um investimento o quanto antes. Analogamente, preferem postergar os desencaixes.
} 
A difusão de uma metodologia que seja amplamente aceita, portanto, é vista como sendo um passo fundamental a ser dado. Para que a contabilidade ambiental permita que se compare o eco-desempenho de diferentes companhias, porém, é imprescindível que se busque uma uniformização não apenas de método de condução do trabalho, mas também da maneira como se apresentam as informações, processo que ainda está se iniciando.

Na última década, têm sido realizados progressos significativos na identificação dos principais aspectos ambientais a incluir nos relatórios e os indicadores apropriados através dos quais o desempenho pode ser calculado e comunicado. Simultaneamente, contudo, tem sido pouco o progresso alcançado no estabelecimento dos funcionamentos conceptuais necessários a uma fundamentação segura que qualquer tipo de informação, interna ou pública, requer e que é um pré-requisito para comparação e benchmarking. (ONU, 2001: 51)

Usando especificamente o exemplo da indústria cervejeira, entretanto, as Nações Unidas apontam para a necessidade de se utilizarem os “portões da empresa” como as fronteiras para a condução desse tipo de estudo, por serem as informações referentes a fornecedores e clientes, freqüentemente, de difícil acesso.

Para a comparação de informação entre diferentes locais de produção existe uma diferença significativa quando, por exemplo, a produção de malte é realizada na cervejeira ou quando esta adquire o malte a um fornecedor externo. Semelhantemente, é importante para a comparação da informação sobre a água e energia o facto de o engarrafamento ocorrer em todas ou só em algumas fábricas, e se as fábricas engarrafam em garrafas de vidro, alumínio ou barril. Muitas cervejeiras também têm uma linha de produção de bebidas não alcoólicas, o que também pode distorcer a comparação. (ONU, 2001: 54)

Para proceder a essas comparações, portanto, todas as fases e processos ocorridos na empresa devem ser cuidadosamente definidos. A transparência ao longo de todo o processo (obtida através da identificação de fluxos de materiais e energia, que por sua vez serão expressos em termos de quantidades, valores e custos associados) é vista como vital para a implementação de medidas integradas capazes de reduzir as tensões ambientais, economizar recursos, incentivar o desenvolvimento de novos produtos, tecnologias e procedimento mais "eco-eficientes", melhorar o fluxo de informações ambientais que apóiem a tomada de decisão e motivar o pessoal. 
Entretanto, a consideração apenas dos custos ambientais gerados no interior das organizações, como sugere o relatório das Nações Unidas, acaba por gerar dificuldades na comparação de alternativas de investimentos que tenham impactos em diferentes pontos do ciclo de vida de um produto. Essas limitações, reconhecidas pela própria ONU, indicam ser necessária a inclusão de informações externas à empresa para que se possa averiguar qual o impacto de um produto ou serviço sobre o meio ambiente, e qual o seu custo para a sociedade como um todo. A ferramenta que, atualmente, se apresenta como a mais promissora nesse sentido é a Análise de Ciclo de Vida.

\section{4 - Análise de Ciclo de Vida}

O conceito de Análise do Ciclo de Vida (ACV) de produtos, embalagens e serviços (ou "funções entregues ao consumidor", como colocam Smith e White, 2000) não é novo. De acordo com Martins (1999), a ACV surgiu na década de 1960, quando a Coca-Cola encomendou um estudo que avaliasse o impacto ambiental total de cada alternativa de embalagem à sua disposição. Porém, a mais ampla difusão do conceito é relativamente recente. Foi apenas em princípios da década de 1990 que a ACV ganhou força como uma das ferramentas a ser utilizadas na gestão ambiental. Seu princípio fundamental é gerar indicadores que permitam avaliar o impacto total da "função" sobre o ambiente, considerando-se todos os insumos nela utilizados e todos os produtos e subprodutos por ela gerados. De acordo com Martins (1999: 30)

A análise de ciclos de vida ACV (...) é uma metodologia de análise que pode ser utilizada para avaliar os efeitos ambientais de um produto, processo ou atividade ao longo de todo o seu ciclo de vida.

Metodologia essa que, para Levy (2000), ainda está em desenvolvimento, mas que tem se mostrado útil no auxílio às decisões das empresas que buscam embalagens com menor impacto ambiental. 
Smith e White (2000) consideram como tendo sido de grande importância para o fortalecimento da ACV o trabalho conduzido pela Society of Environmental Toxicology and Chemistry (SETAC), organização que buscou construir um referencial conceitual que serviu de paradigma para o desenvolvimento das primeiras análises de impacto ambiental de um produto durante todo o seu ciclo de vida. Tendo como base o trabalho da SETAC, a International Standards Organisation (ISO) passou a incorporar normas específicas sobre gestão ambiental, entre as quais se encontram as que compõem a série ISO $14040^{24}$ sobre análise de ciclo de vida. Essa série tenta estabelecer uma estrutura flexível para a condução dos estudos sobre ciclo de vida, de forma que particularidades de cada organização possam ser contempladas. A contrapartida dessa flexibilidade é a exigência de que as premissas e valores usados na análise sejam cuidadosamente documentados para futura verificação.

De acordo com a ISO, as principais etapas da ACV são quatro, e podem ser vistas na figura 2.1:

(1) Definição de Objetivos e Escopo - Deve-se identificar a proposta do estudo, suas fronteiras e os procedimentos que serão utilizados na manipulação dos dados. Teoricamente, todos os processos necessários para a execução do produto, embalagem ou serviço devem estar contidos nessa etapa. Na prática, contudo, alguns processos acabam sendo excluídos (quando, por exemplo, são idênticos em todos os sistemas que estão sendo comparados).

(2) Inventário de Ciclo de Vida - Esta etapa envolve a contabilização dos insumos utilizados e dos produtos e subprodutos gerados na produção que se está analisando. Esses inputs e outputs são também conhecidos como fluxos elementares, e devem ser rastreados, sempre que possível, de sua saída até o retorno ao meio natural, e devem ser identificados e quantificados separadamente no inventário. Evidentemente, é mais fácil

\footnotetext{
${ }^{24}$ ISO 14040 Gestão ambiental - Análise de ciclo de vida - princípios e conceitos; ISO 14041 Gestão ambiental - Análise de ciclo de vida - Definição de Objetivos e Escopo e Análise de Inventário; ISO 14042 Gestão ambiental - Análise de ciclo de vida - Análise de Impacto; e ISO 14043 Gestão ambiental - Análise de ciclo de vida - Análise de Melhorias.
} 
contabilizar as informações que são de propriedade da organização que está conduzindo a análise, uma vez que dados de fornecedores (ou de fornecedores desses fornecedores) e de clientes (ou clientes dos clientes) podem ser inacessíveis.

(3) Análise de Impacto do Ciclo de Vida - É a etapa que transforma as informações contidas no inventário em indicadores que permitem associar ações a possíveis efeitos sobre o ambiente. O maior problema aqui é que se assume uma relação linear de causa e efeito para avaliar possíveis impactos ambientais da produção, mas tal linearidade ocorre apenas em casos raros. Daí a necessidade de que se utilizem as informações geradas pela ACV apenas como indicadores.

(4) Interpretação - As três etapas anteriores estão sujeitas à interpretação de quem conduz o estudo, o que significa que julgamentos de valores estão invariavelmente envolvidos na ACV. É preciso, por isso, que haja uma revisão crítica de cada informação levantada, assim como análises de sensibilidade e incerteza que ajudem a identificar se as premissas das quais se partiu são de fato as mais relevantes, e quais delas têm a maior influência nos resultados obtidos.

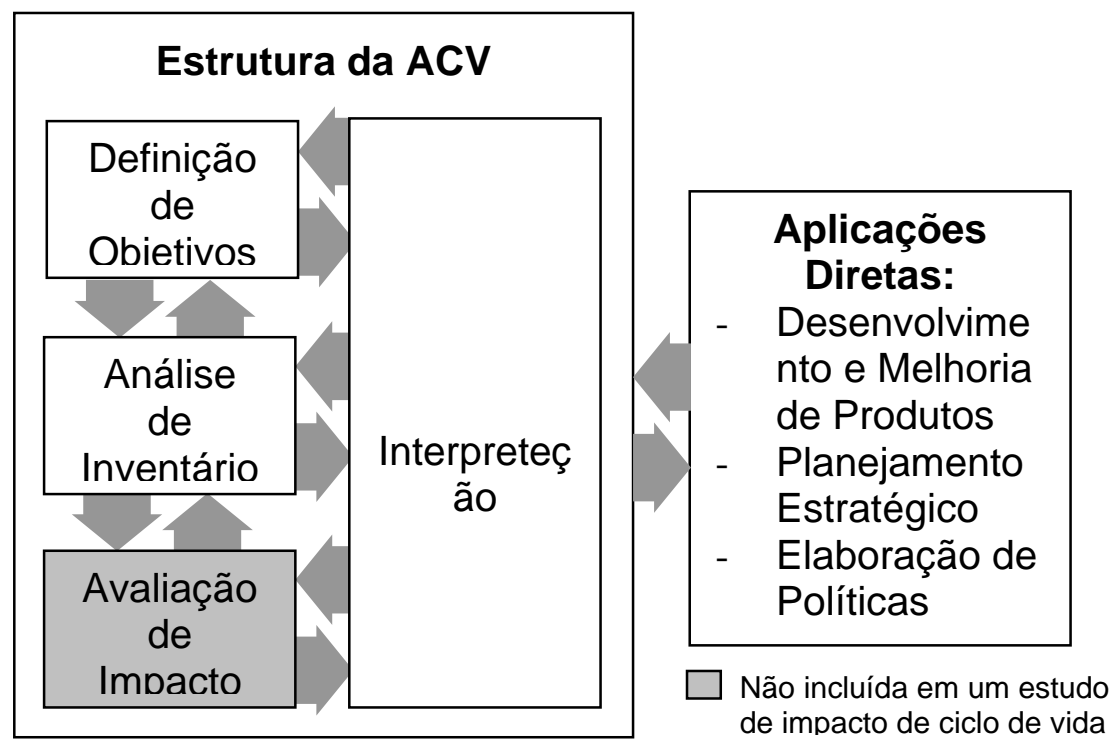

Fig. 2.1 - Fases da ACV (Smith \& White, 2000: 186) 
Apesar desse esforço para uniformizar os critérios de aplicação da ACV, Martins (1999: 45) lembra que não há, ainda, nenhuma metodologia universalmente aceita para tais estudos, que encontram na dificuldade de se atribuírem valores aos impactos ambientais o seu maior obstáculo, a exemplo do que ocorre com a contabilidade ambiental:

[D]esenvolver técnicas explícitas e sistemáticas para integrar e elucidar a enorme gama de valores associados [à fase de valoração dos impactos ambientais] talvez seja o componente central do conceito da metodologia da [ACV] que ainda não foi devidamente explorado.

De todas as possíveis aplicações da ACV, o estudo no campo das embalagens acabou sendo o mais recorrente (Levy, 2000). As prováveis razões para isso são diversas, e podem ser buscadas, entre outros fatores, na limitada quantidade de materiais e processos necessários para a produção de embalagens (quando comparada a produtos), o que torna a ACV mais viável; na importância (senão científica, ao menos política) do tema referente ao descarte das embalagens; e na maior disponibilidade de bancos de dados sobre os diferentes materiais de embalagem.

O fato é que, quando comparada com outras ferramentas de gestão ambiental, a ACV tem duas vantagens principais. A primeira delas é que todo o ciclo de vida da embalagem (ou outra "função”) é analisado, da extração das matérias-primas ao descarte, e contabiliza-se todo o processo. Com isso, impede-se que haja uma “postergação do problema” com a transferência do efeito negativo sobre o ambiente para outras etapas da produção, ou mesmo para outros locais. Isso fica claro quando se observa o diagrama da figura 2.2, que representa o ciclo de vida de uma embalagem. 


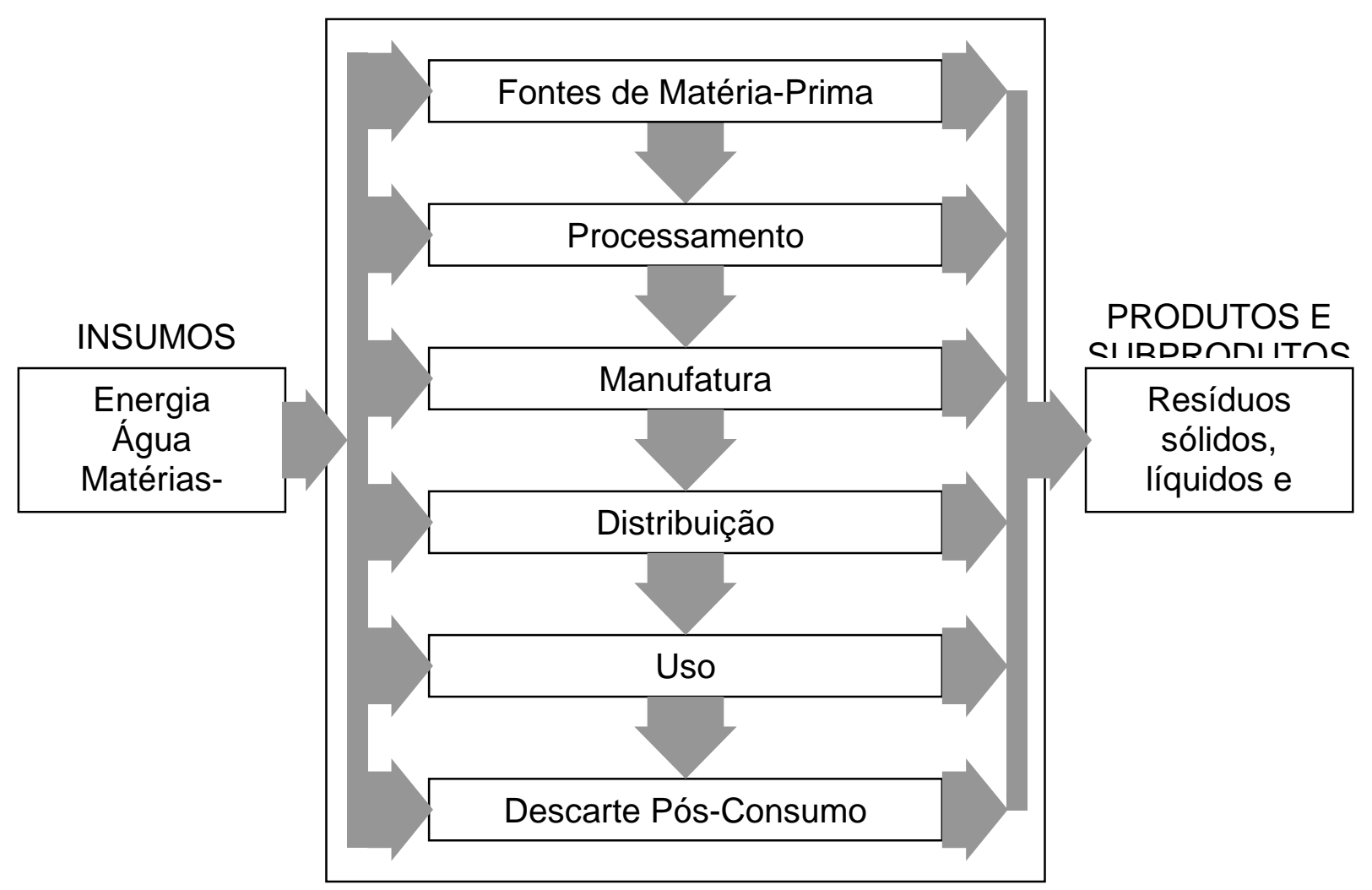

Fig. 2.2 - Ciclo de Vida de uma Embalagem (Smith e White, 2000: 182)

A segunda vantagem da ACV em relação às demais ferramentas de gestão ambiental é que, com a contabilização de todos os insumos, produtos e subprodutos, pode-se calcular a utilização de recursos e a geração de resíduos associadas ao desenvolvimento da “função" (a “unidade funcional”, conforme colocam Smith e White, 2000). Isso permite a comparação de sistemas diferentes que colocam a mesma função à disposição da sociedade. Diferentes embalagens, por exemplo, podem ser comparadas em quantidade (por quilo, por litro etc.) de produto entregue ao consumidor. Evidentemente, outros fatores devem ser considerados na análise, de forma a se ter uma visão do impacto geral do sistema sobre o ambiente (no caso de embalagens, tais fatores podem ser, por exemplo, proteção, funcionalidade e barreiras a gases). 
No que pesem as dificuldades da ACV, essa metodologia, desde que foi criada, tornou-se uma quase unanimidade nas discussões sobre a administração de resíduos sólidos, e passou a ser defendida pela indústria, por agências governamentais e por grupos ambientalistas. A difusão da idéia foi tamanha que a ACV chegou a servir de referência na formulação da legislação européia sobre a administração dos resíduos sólidos (a Diretiva, por exemplo, sugere que a ACV seja conduzida "o mais rápido possível” a fim de que se justifique uma hierarquia clara entre embalagens reutilizáveis, recicláveis e recuperáveis).

Entretanto, apesar da grande aceitação da ACV como ferramenta útil na análise do impacto ambiental de produtos, embalagens e serviços, tornou-se claro, com o passar do tempo, que ela sozinha não seria capaz de dar respostas definitivas sobre qual seria “o melhor” processo produtivo, “o melhor” material ou "o melhor" sistema de embalagens.

Primeiro, porque os dados existentes no mercado sobre diferentes materiais e processos que devem ser empregados na análise ainda não são padronizados ${ }^{25}$ (essa dificuldade operacional é lembrada por autores como Martins, 1999, para quem deve haver muito cuidado no momento da coleta de dados, de maneira que sejam geradas informações com a maior precisão possível). Depois, porque a ACV traz consigo um dilema intrínseco, que é a incapacidade de que se avaliem com precisão os efeitos ambientais efetivos do produto, embalagem ou serviço, visto que o próprio sistema de contabilização empregado pela $\mathrm{ACV}$ e a unidade de análise que se utiliza (a “unidade funcional”) buscam integrar a utilização de recursos e os resíduos gerados em diferentes unidades de tempo e espaço. A variável "tempo", aliás, é vista por estudiosos do tema (Barde \& Pearce, 1995; Pearce et al., 1992) como um fator complicador nas análises de custos ambientais, decorrência das preferências de tempo dos agentes econômicos. O resultado prático, no presente contexto, é que benefícios ambientais aferidos no longo prazo (ganhos para gerações futuras, por exemplo), seriam menos valorizados do que benefícios obtidos imediatamente.

\footnotetext{
${ }^{25}$ A série ISO 14040 é resultado de um esforço para minimizar essa deficiência.
} 
Os efeitos ambientais efetivos dos resíduos gerados por um produto, embalagem ou serviço, portanto, dependem de quando, onde e como os resíduos são descartados no ambiente, dificultando a avaliação do seu impacto efetivo. Nas palavras de Smith e White (2000: 183),

O dilema fundamental, portanto, é que a ACV é a única ferramenta que tenta incluir todo o ciclo de vida e todas as questões associadas a um produto, embalagem ou serviço, e é a única que relaciona esses fatores à unidade funcional, e no entanto não consegue prever os seus prováveis efeitos efetivos. Outras ferramentas, como a avaliação de risco, são capazes de prever os possíveis efeitos efetivos, mas não incluem todas as questões ambientais durante o ciclo de vida, e tampouco relacionam esses efeitos à unidade funcional.

Por esse motivo, alguns autores (Levy, 2000; Smith \& White, 2000) enxergam a ACV como uma ferramenta útil na gestão ambiental, mas recomendam a sua utilização em conjunto com outras ferramentas. Na opinião de Smith e White (2000), o objetivo principal quando se realiza a ACV pode ser descrito como sendo a "gestão ambiental na direção da sustentabilidade que seja economicamente (e tecnicamente) viável e socialmente aceitável” (p. 179). Na busca por essa “sustentabilidade”, portanto, produtos, embalagens e processos precisam atender a quatro quesitos básicos, que Smith e White chamam de estrutura de gestão ambiental (ver figura 2.3):

(a) Segurança, tanto para as pessoas quanto para o ambiente, que deve ser garantida em todos os estágios do ciclo de vida, da manufatura ao descarte final, passando pela distribuição e pelo uso.

(b) Conformidade com a letra e com o espírito da lei.

(c) Eficiência na utilização de recursos (matérias-primas e energia) e na administração de resíduos. É nesse ponto que a ACV se encaixa, ao permitir que se levantem os insumos utilizados na produção e os produtos e subprodutos dela resultantes. Com isso, torna-se possível trabalhar no sentido da eco-eficiência e da sustentabilidade para que se produza mais (produtos, valor) com menos (recursos, resíduos). Essa abordagem do fazer “mais com menos” reforça a posição de Porter e Van der Linde (1995) e da ONU (2001) de que qualquer perda deve ser encarada como desperdício, e 
que ferramentas de análise econômica que incorporem custos ambientais devem ser empregadas quando se discute a utilização eficiente de recursos.

(d) Observância das preocupações da sociedade (com relação ao produto, embalagem ou processo em questão). Esta talvez seja a área mais conturbada para as empresas, uma vez que há elementos de forte apelo emocional e crenças do que sejam "comportamentos corretos” que podem afetar o julgamento dos stakeholders a respeito de determinadas ações das empresas. Nesse sentido, ferramentas como a ACV podem ajudar a retirar a carga emocional da discussão. 


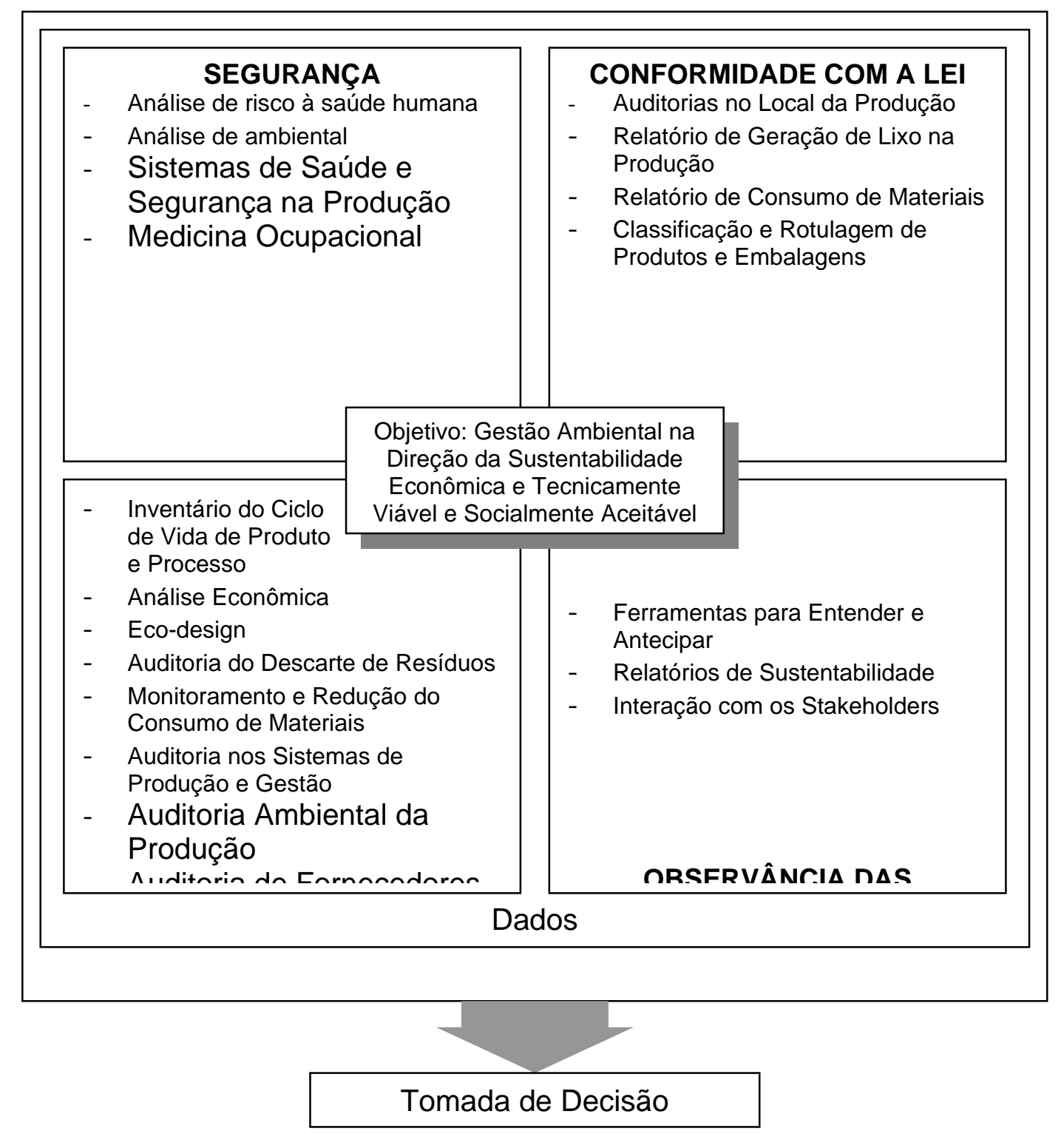

Fig. 2.3 - Estrutura de Gestão Ambiental (Smith e White, 2000: 180)

No caso de embalagens, a ACV presta-se, portanto, a auxiliar os profissionais envolvidos no lançamento ou na administração de um produto a identificar onde há utilização significativa de recursos, e em que pontos do ciclo de vida há a maior probabilidade de que haja a geração de resíduos. Com isso, torna-se possível avaliar onde aperfeiçoamentos podem ser feitos. 
Smith e White (2000) lembram, contudo, que apesar de a maior parte dos estudos enfocarem isoladamente os sistemas de embalagem, as embalagens deveriam ser consideradas de uma forma mais ampla, como parte integrante do sistema do produto que acondicionam. Nas palavras deles,

\begin{abstract}
Mudanças no sistema de embalagem, tais como a forma como o produto é dispensado durante o uso ou melhorias no nível de proteção ao produto, podem levar a economias significativas no volume de produto que é desperdiçado entre a produção e o uso. Da mesma forma, mudanças no produto, como alterações na sua concentração, podem alterar significativamente o volume necessário de embalagens por uso do produto. Essa interdependência significa que as ACVs deveriam, quando possível, considerar o ciclo de vida do produto em conjunto com a sua embalagem. (p. 192)
\end{abstract}

Um corolário disto é que não se pode afirmar com certeza, a priori, que um sistema de embalagem é “melhor” ou “pior” do que outro em termos ambientais. Análises de ciclo de vida precisam ser conduzidas caso a caso. Às vezes, a ACV indica caminhos contrários ao que o "senso comum" indica ${ }^{26}$.

Por isso, Juchem (1995) acha útil que sejam conduzidos estudos de ciclo de vida de produtos, para que se analisem os impactos que esses podem ter sobre o ambiente. Porém, o autor considera que uma abordagem mais moderna consiste em avaliar os impactos e conseqüências ambientais de novas tecnologias, ou seja, "estudar os efeitos ambientais de novos produtos antes de eles serem produzidos e colocados no mercado” (p. 24). Harris e Goodwin (2001: xxxiv) corroboram essa visão, ao afirmar que

Sustentabilidade é mais do que limitar o crescimento populacional ou restringir o consumo - apesar de isso ser importante. Significa que nas nossas escolhas por bens e tecnologias precisamos nos orientar pelos requisitos da integridade do ecossistema e da diversidade das espécies. Implica também em reconhecer que a aparente independência entre a economia e a ciência biofísica é um luxo ao qual não podemos nos dar.

\footnotetext{
${ }^{26}$ Um estudo conduzido no Reino Unido mostrou que, ao contrário do que se acreditava, embalagens individuais e mais reforçadas tinham um impacto menor sobre o meio ambiente do que embalagens com maior conteúdo e que buscavam uma redução no volume utilizado de material de embalagem. Isso porque reduziam o desperdício de produtos gerado por sobras e por produtos danificados. (Smith \& White, 2000)
} 
Outra conseqüência da maior atenção dada à consideração de toda a cadeia produtiva na análise da geração de resíduos ligados ao consumo é a criação de um novo conceito que tem permeado as discussões sobre políticas ambientais, batizado de Política de Produto Integrado (PPI). Em linhas gerais, a PPI pode ser definida como uma política pública que procura, de forma explícita, modificar e melhorar o desempenho ambiental de sistemas de produtos (Levy, 2000). Seus cinco pilares fundamentais são:

(1) Administração de Resíduos, com vistas a reduzir e gerir resíduos criados durante o consumo de produtos;

(2) Inovações de Produtos “Verdes”, buscando incentivar o desenvolvimento de produtos menos danosos ao meio ambiente;

(3) Criação de Mercados, com o intuito de desenvolver mercados capazes de absorver os produtos “verdes” criados;

(4) Transmissão de Informações Ambientais, visando à difusão, ao longo da cadeia produtiva, de informações capazes de levar ao desenvolvimento de tais produtos; e

(5) Atribuição de Responsabilidades, de forma que cada agente econômico assuma a sua parcela de responsabilidade no processo.

A grande diferença da PPI com relação à abordagem mais tradicional das políticas de meio ambiente é que ela cobre todos os sistemas produtivos e seus efeitos ambientais, partindo da perspectiva da ACV. A PPI abrange, portanto, desde a extração das matérias-primas até o descarte do produto, incluindo também o processamento dos materiais, a produção, a distribuição e o uso. A PPI é vista por Levy (2000) como um passo importante na busca do desenvolvimento sustentável, por propiciar uma abordagem que perpassa toda a cadeia produtiva.

Um dos propulsores do pensamento da PPI são as potenciais mas significativas melhorias ambientais que podem ser alcançadas quando se olha a política ambiental pelas "lentes" de cada setor produtivo, selecionando áreas prioritárias para melhorias e decidindo sobre as políticas e as medidas de mercado mais apropriadas para alcançar essas melhorias. Reconhece-se que este processo é inerentemente mais complexo que as abordagens tradicionais à política ambiental porque sua aplicação envolve setores produtivos inteiros e precisa ser desenhada ou customizada conforme circunstâncias de mercado específicas. (Levy, 2000: 21). 
Isso significa que não se deve encarar a embalagem como um produto em si, mas que se deve considerá-la em conjunto com o produto que acondiciona. A integração sistemática de considerações ambientais no desenvolvimento de produtos e processos é o que se chama de Ecodesign, ou Design for Environment, elemento fundamental no caminho do desenvolvimento sustentável.

\section{5 - Logística Reversa}

Indissociavelmente articulado com as discussões sobre contabilidade ambiental e análise de ciclo de vida está o conceito de logística reversa, ferramenta importante do ecodesign que tem ganhado força desde a década de 1980, mas que apenas a partir dos anos 1990 passou a ser discutida com maior intensidade (Grisi et al., 2003) $)^{27}$.

O Conselho Executivo de Logística Reversa define o termo como sendo

o processo de movimentação de produtos da sua típica destinação final para outro ponto, com o propósito de capturar valor ou enviá-lo para destinação segura (Reverse Logistics Executive Council, apud Grisi et al., 2003).

Grisi et al. (2003), entretanto, após proceder a uma revisão do estado da arte sobre o assunto, indicam que há outros aspectos da logística reversa que devem ser considerados. Resumindo o que tais autores apresentam, podemos dividir logística reversa em cinco funções básicas e interligadas:

(a) O planejamento, a implementação e o controle do fluxo de materiais e do fluxo de informações, do ponto de consumo ao ponto de origem;

(b) A movimentação de produtos na cadeia produtiva, na direção do consumidor para o produtor;

\footnotetext{
${ }^{27}$ Esses autores identificaram como a primeira menção ao conceito de logística reversa o trabalho de Zikmund e Stanton (Zikmunnd, William G. \& Stanton, William Z. (1971). Recycling Solid Wastes: a Channel of Distribution Problem. Journal of Marketing, July).
} 
(c) A perseguição de uma melhor utilização de recursos, seja reduzindo o consumo de energia, seja diminuindo a quantidade de materiais empregada, seja reaproveitando, reutilizando ou reciclando resíduos;

(d) A recuperação de valor; e

(e) A segurança na destinação do produto após a sua utilização.

A logística reversa é vista por Grisi et al. (2003) como sendo influenciada em três níveis distintos. O primeiro deles refere-se às demandas ambientalistas que têm levado as empresas a se preocupar com a destinação final de produtos e embalagens por elas gerados. O segundo é a eficiência econômica, já que a logística reversa permite a geração de ganhos financeiros pela economia no uso de recursos. O terceiro nível está ligado ao ganho de imagem que a empresa pode ter perante seus stakeholders.

Em estudo sobre a questão da responsabilidade social corporativa, Machado $\mathrm{F}^{\circ}$ (2002) já demonstrara que a reputação é um ativo extremamente importante das empresas, com impacto positivo sobre a elevação de seu valor - opinião que é compartilhada pela ONU (CEPAL \& PNUMA, 2002). Isso dirime eventuais dúvidas que possam existir sobre a incompatibilidade entre as ações de responsabilidade social ou ambiental e elevação do valor da empresa para os acionistas. Para Machado $\mathrm{F}^{\mathrm{o}}$ (2002: 60)

\footnotetext{
Os ativos intangíveis tornam-se crescentemente a base de diferenciação entre muitos setores (...) Ou seja, atualmente, dada a maior facilidade tecnológica e mercadológica de replicação de práticas e condutas, o fator da diferenciação para obtenção de vantagens competitivas passa a ser, em grande medida, a percepção do público sobre a reputação da empresa.
}

Do que foi exposto acima, pode-se depreender que a preocupação com o meio ambiente é um dos principais propulsores da logística reversa, que tem ganhado força com a consolidação de metodologias que permitem a mensuração de valores ambientais. Percebe-se, também, que o consumerismo “verde” pode representar boas oportunidades para as empresas que tiverem atividades ambientalmente 
responsáveis, por causa da possibilidade de que se reduza o consumo de materiais através do emprego da logística reversa. Recorrendo novamente a Grisi et al., 2003):

\footnotetext{
Embora represente uma ameaça ao tradicional marketing de consumo, o Green Marketing pode apresentar também oportunidades antes nunca exploradas. Novas estratégias deverão ser aplicadas e os administradores que se anteciparem nesse sentido poderão propiciar vantagens competitivas novas e fundamentais para suas empresas e produtos.
}

Esses autores ressaltam ainda que, quando se trabalha a partir da perspectiva da logística reversa, fica claro que o desenvolvimento de produtos "verdes" é um processo que envolve uma série de fatores que transcendem a reciclabilidade das embalagens. Incluem-se aí fatores ligados ao desenvolvimento do produto que permitem a visualização do seu ciclo de vida sob a ótica do marketing “verde”. Na contramão desses argumentos, contudo, os autores constataram em sua pesquisa que a maior parte dos apelos ambientais das empresas ainda se refere à possibilidade de reciclagem das embalagens. Os resultados do trabalho de Grisi et al. (2003) mostram também que a preocupação com o meio ambiente ainda não é generalizada entre as empresas brasileiras, sendo as corporações de maior porte as que mais se mostram atentas à questão. São essas mesmas empresas, conseqüentemente, as que mais têm investido recursos em logística reversa.

Isso mostra o quanto o mercado brasileiro ainda é incipiente em termos de aplicação dos conceitos acima discutidos. É possível, entretanto, que os fatores identificados por Grisi et al. (2003) - pressões de grupos ambientalistas, eficiência econômica e ganhos de imagem corporativa - passem a influenciar crescentemente os negócios na direção da sustentabilidade.

\section{6 - Comportamento do Consumidor}

Uma estratégia de posicionamento representa os esforços de uma empresa para comunicar às pessoas no mercado que seus produtos e marcas têm certas características que podem satisfazer as necessidades e desejos de seu público-alvo. 
Porém, a decisão final de comprar (ou não) o que está sendo oferecido pertence ao consumidor - uma decisão que as empresas podem, na melhor das hipóteses, tentar entender e influenciar.

Kotler e Armstrong (1998) definem como sendo a questão fundamental que se coloca para os profissionais de marketing a forma com que os consumidores respondem aos vários estímulos de marketing emitidos pela empresa. Em outras palavras, os autores acreditam que é fundamental entender o comportamento do consumidor, tentar encontrar um determinado padrão de resposta ao composto de marketing por parte daqueles que compõem o público-alvo da empresa, de maneira que se busque uma redução na probabilidade de erro quando decisões de marketing precisam ser tomadas.

Deve-se, para isso, procurar identificar não apenas o que o consumidor quer, mas como, onde e quando ele quer consumir. Além disso, reconhece-se hoje que as trocas entre compradores e aqueles que ofertam produtos ou serviços não se limitam ao processo de compra em si (Aaker, 1996; Kapferer, 1997; Elliott \& Wattanasuwan, 1998). Há muitas interações dos dois lados, anteriores e posteriores à compra do produto. Isso evidencia que o entendimento do comportamento dos consumidores é uma tarefa extremamente complexa, que tem um papel central na definição da estratégia de marketing a ser adotada.

Algumas ferramentas administrativas que utilizam conhecimentos gerados na economia, na psicologia, na sociologia e em outros campos das ciências sociais podem ser úteis nessa tentativa de decodificar o comportamento do consumidor que, conforme Engel et al. (1994: 4), refere-se “àquelas atividades diretamente envolvidas na obtenção, consumo e descarte de produtos e serviços, incluindo os processos de decisão que precedem e seguem estas ações.” O objetivo final deste esforço é aproximar o máximo a oferta de produtos e serviços dos desejos de consumo.

Há diferentes abordagens ao tema Comportamento do Consumidor que, de acordo com Engel et al. (1994), podem ser divididas em três correntes teóricas gerais. A primeira delas, chamada de perspectiva de influência do consumidor, usa o ponto de vista das pessoas que desejam afetar o comportamento do consumidor 
(profissionais de marketing, formuladores de políticas públicas e agentes de proteção e educação dos consumidores, por exemplo). Os objetivos básicos de quem segue essa linha de pesquisa, que se apóia eminentemente na lógica positivista, são entender e prever o comportamento do consumidor e procurar relações de causa e efeito que possam resultar em ações de persuasão e/ou de educação dos consumidores.

Uma segunda abordagem, bem distinta da anterior, é a perspectiva pósmoderna, cujo objetivo é entender a lógica do consumidor, sem contudo tentar influenciá-lo. O foco das pesquisas que seguem essa linha é colocado nos aspectos experienciais do consumo, na busca de sensações, na fantasia e nos aspectos emocionais desencadeados pelo consumo.

Finalmente, uma terceira corrente teórica é a chamada por Engel et al. (1994) de perspectiva global intercultural, que assume que as necessidades e os processos decisórios dos consumidores são universais, mas reconhece que "há grandes diferenças culturais nas maneiras com que motivação e comportamento ocorrem na prática” (p. 10).

$\mathrm{Na}$ ótica desses acadêmicos, quando se fala em comportamento do consumidor há que se observar quatro princípios subjacentes, a saber:

1) O consumidor é soberano: isso implica na necessidade de que, num ambiente competitivo, as motivações e o comportamento do consumidor sejam compreendidos.

2) Pesquisa é necessária: entender os fatores que motivam o consumidor e o levam a escolher comportamentos específicos é uma tarefa que pode ser executada suficientemente, a ponto de minimizar equívocos na estratégia de marketing.

3) O comportamento do consumidor pode ser influenciado: uma cuidadosa estratégia de marketing, se bem executada, pode lograr êxito em levar os consumidores a alterar seus comportamentos, ao afetar as suas motivações e ofertar produtos e serviços que estejam de acordo com as suas necessidades e expectativas. 
4) A legitimidade, sob a perspectiva da ética, das ações que visem a influenciar o consumidor: nenhuma estratégia de marketing que tenha por objetivo modificar comportamentos pode se utilizar de manipulações ou fraudes, devendo os direitos do consumidor ser respeitados sempre, prioritariamente.

Comportamento do consumidor pode ser entendido, então, como o estudo dos processos envolvidos nas escolhas, nas compras, nos usos e no descarte não apenas de produtos, mas também a serviços, idéias e experiências que satisfaçam os desejos e as necessidades de indivíduos ou grupos. Esses processos podem variar quanto ao grau de complexidade, dependendo do nível de envolvimento que o consumidor tem com a compra. Nessa linha, quando há alto envolvimento, o processo decisório tende a ser mais rebuscado - o que Engel et al. (1994) chamam de Solução Extensiva de Problema. No outro extremo estariam as chamadas compras habituais e repetitivas (Soluções Limitadas de Problema $^{28}$ ), nas quais o processo decisório torna-se "inercial”.

Dentre os grupos de fatores e determinantes que influenciam o processo decisório dos consumidores, Engel et al. (1994) destacam três. O primeiro conjunto refere-se às diferenças individuais, com relação aos recursos que cada consumidor tem à sua disposição (tais como tempo, dinheiro e capacidade de processamento de informações), ao nível de conhecimento de cada um, nas atitudes, à motivação e aos aspectos psicográficos (como personalidade, valores e estilo de vida). O segundo grupo é o das influências ambientais, expressas nas origens culturais, refletidas na classe social, afetadas pelos grupos de referência, pelo contexto etc. Finalmente, um terceiro conjunto é formado por processos psicológicos, como o processamento de informações, a aprendizagem e as mudanças em atitudes e comportamentos. Os consumidores, portanto, podem ser influenciados por fatores dos mais diversos, tais como a aparência do produto e a aceitação (ou rejeição) por parte do seu grupo de referência.

\footnotetext{
${ }^{28}$ Engel et al. (1994) consideram as compras por impulso uma categoria especial de Solução Limitada de Problemas.
} 
De uma maneira geral, o estudo do comportamento do consumidor, tão importante como a cuidadosa segmentação do mercado, é requisito fundamental na definição da estratégia de posicionamento. Em última análise, é o entendimento de como o consumidor reage ao ambiente que o circunda que vai definir todo o composto de marketing. Conhecer suas características demográficas é um fator importante, mas é preciso que se vá muito além, identificando seus valores e crenças mais profundos.

É preciso que se ressalte que não se deve levar em conta apenas o comprador de um determinado produto ou serviço na hora de elaborar o plano de marketing. Outros agentes, que possuem diferentes papéis no processo de compra, tais como influenciadores e usuários, também devem ser objeto de criteriosa análise (Engel et al., 1994).

\section{7 - Comportamento “Verde” do Consumidor}

Com o aumento das pressões políticas e sociais em favor de uma mudança nos padrões de consumo que buscasse a maior preservação ambiental, muitas empresas passaram a se preocupar em modificar seus produtos, incluindo nisso suas embalagens (Straughan \& Roberts, 1999). O consumerismo “verde”, que esses acadêmicos preferem denominar “comportamento do consumidor ecologicamente consciente” (CCEC), é um dos pilares que formam a base da argumentação do presente trabalho.

Partindo-se do que foi colocado na seção anterior, percebe-se o quão importante, então, passa a ser a compreensão, por parte das empresas, do comportamento do consumidor ligado a assuntos ambientais. Nas palavras de Stern (1999: 461),

\footnotetext{
Alterar o comportamento do consumidor pode fazer uma diferença significativa para o meio ambiente, e a pesquisa sobre o consumidor pode auxiliar os formuladores de políticas a entender esse comportamento, para melhor influenciá-lo.
} 
Straughan e Roberts (1999) indicam que, desde que a questão ambiental ganhou corpo, buscam-se indicadores para explicar a maior ou menor propensão das pessoas a terem um comportamento ecologicamente consciente. Segundo eles, muitas tentativas se apoiaram em variáveis demográficas - como idade, sexo e renda - para dar conta de tal fenômeno. Outros estudos procuraram identificar variáveis psicográficas - como altruísmo e preocupação ambiental - que correlacionassem atitudes e comportamentos "verdes".

Baseando-se em critérios de avaliação de segmentos de mercado ${ }^{29}$ semelhantes aos propostos por Engel et al. (1994), Straughan e Roberts (1999) concluíram que a existência de um grupo de consumidores “verdes” é inquestionável, e que as variáveis psicográficas são mais apropriadas que as demográficas para identificá-lo. Eles explicam, entretanto, que tanto umas quanto as outras são significativamente correlacionadas com o comportamento do consumidor ecologicamente responsável, quando consideradas separadamente, mas que, se usadas em conjunto, formam um modelo melhor.

Reconhecem-se como fatores que influenciam o comportamento do consumidor, portanto, não apenas os estímulos emitidos pela empresa (as chamadas "variáveis controláveis"), mas também fatores que lhe escapam ao controle (“variáveis incontroláveis”). Nessa linha, refletindo o crescimento das preocupações ambientais, amplificado pela cobertura da mídia, estudiosos têm debatido se o modo como os consumidores administram suas vidas é ou não afetado por questões “verdes” (Mainieri et al. 1997; Peattie, 1992, 1999, 2001; Stern, 1999; Thøgersen, 1999). A visão predominante parece ser a de que o comportamento de compra pode ser afetado por assuntos ambientais, o que sugere que a dimensão "verde" tem de ser considerada nas decisões de marketing (Wagner, 1997).

Mainieri et al. (1997), por sua vez, crêem que o comportamento do consumidor é uma função não apenas de aspectos situacionais, mas também de características pessoais. Eles identificaram em sua pesquisa que indivíduos que separam lixo para

\footnotetext{
${ }^{29}$ Tamanho do segmento, acesso ao segmento, facilidade de identificação, efetividade estratégica e operacional, e estabilidade do segmento.
} 
reciclagem têm maior propensão a se preocupar com o impacto ambiental das embalagens que compram. Por isso, argumentam que o comportamento "verde" do consumidor depende tanto do reforço das crenças individuais a favor de ações ambientalmente melhores quanto da busca por melhores condições estruturais (como disponibilidade, conveniência etc.).

Nessa linha, Straughan e Roberts (1999) dão uma grande contribuição à discussão ao relativizar a importância da preocupação com o ambiente na promoção de um comportamento mais “verde”. Nas palavras desses autores,

O mais surpreendente para os presentes autores é a descoberta de que, apesar de significativa, a preocupação ambiental não responde integralmente pelo CCEC. É mais importante os consumidores acreditarem na eficácia dos indivíduos no combate à destruição ambiental do que demonstrarem preocupação com o ambiente. (p. 570)

Como sublinhado anteriormente, são os consumidores os atores para quem, em última instância, são dirigidos os esforços de marketing. Eles representam o elo de ligação entre a empresa e os seus resultados.

O objetivo desta seção é verificar quais fatores podem interferir no processo de decisão de compra dos consumidores quando questões ambientais são levadas em conta por eles, e se produtos que se posicionam como "mais verdes" que seus substitutos potenciais teriam, por isso, maior chance de ser considerados no momento da compra. Antes, porém, há que se fazer algumas considerações.

\subsection{1 - O que pode motivar um comportamento “mais verde”? Identificado} o desequilíbrio existente entre a importância do meio ambiente para os negócios e a realidade das práticas produtivas, vislumbra-se uma grande oportunidade para as empresas ecologicamente responsáveis que se posicionem como tal, desde que consigam alavancar comportamentos ambientalmente mais saudáveis por parte dos consumidores que compõem o seu público-alvo (Porter e Van der Linde, 1995). Para isso, é preciso que se achem respostas para a pergunta que dá o título a esta seção, respostas essas que hoje são procuradas por diversos agentes econômicos.

Com base na teoria da utilidade, que assume que os consumidores buscam sempre maximizar a utilidade em suas decisões de compra (a consideração dos 
benefícios - advindos do uso do produto e de fatores psicológicos - que serão adquiridos a um dado custo - composto por variáveis como preço, esforço e tempo), Bei e Simpson (1995) argumentam que, para maximizar a compra de produtos ambientalmente amigáveis, os consumidores devem perceber maior utilidade na compra desses produtos do que na aquisição dos chamados produtos “comuns” aqueles que não priorizam aspectos ambientais. Ou seja, para esses autores, hábitos de compra mais "verdes” dependem de os consumidores encontrarem fontes de utilidade adicional nos produtos que se dizem mais ecológicos que os concorrentes.

Os resultados do estudo conduzido por Bei e Simpson (1995) sugerem que a predisposição dos consumidores para comprarem produtos ambientalmente melhores pode ser aumentada quando se enfatizam fatores como a importância do meio natural, atitudes favoráveis a tais produtos e a sensação de que se está contribuindo para a preservação da natureza com a opção por consumir esses itens.

Entretanto, uma melhor compreensão do comportamento "verde" do consumidor não é importante apenas para empresas que procuram aproveitar oportunidades comerciais. O setor público também tem muito com o que se beneficiar (Levy, 2000). Por isso, as discussões sobre o tema são sempre permeadas pelos mais diversos interesses econômicos e políticos, o que tem gerado um amplo (na intensidade e no espectro social) debate - essencialmente nos países mais avançados. Quando se discute o comportamento do consumidor, essas discussões podem se tornar uma rica fonte de informações.

Frey (1999: 395-6), com a intenção de subsidiar formuladores de políticas ambientais, fez um levantamento da literatura publicada sobre o assunto e identificou duas principais - e freqüentemente antagônicas - vertentes teóricas que procuram explicar os fatores que motivariam as pessoas a ter um comportamento ecologicamente “mais correto":

De um lado, há os 'Moralistas', que olham para o ambiente como um assunto ético. (...) Os seres humanos são capazes de - e deveriam ter - uma moral ambiental elevada. (...) Esse comportamento ambientalmente responsável é apoiado por uma educação correspondente. (...)

Do outro lado estão os 'Racionalistas'. Estes são tecnocratas convencidos da capacidade que a tecnologia moderna tem para resolver problemas ambientais, e economistas 
convencidos da capacidade dos seres humanos em superar problemas ambientais se os incentivos corretos forem aplicados.

Os moralistas, na concepção de Frey, pregam que, uma vez que algumas pessoas não estão preparadas para agir moralmente, a proteção ambiental deveria ser alcançada por um sistema de comando-e-controle. Os racionalistas, para quem os problemas ambientais existem porque não há custos diretos associados a eles, acham que instrumentos econômicos seriam suficientes para reduzir os impactos ambientais do consumo e da produção. Uma boa política ambiental, de acordo com esse estudioso, deveria combinar as duas abordagens - embora o próprio autor não tenha sugerido um modelo para essa integração (Uusitalo,1999).

A discussão proposta por Frey, ainda que não tenha tido por finalidade discutir o comportamento "verde" do consumidor, traz conceitos importantes. Ela baseia-se nas idéias de motivações intrínsecas e extrínsecas, e mostra que uma afeta a outra (um fenômeno que o acadêmico chama de "efeitos de agregação" - crowding effects). Isso, sugere a idéia apresentada por Frey, demonstra que confiar pura e simplesmente nas atitudes altruísticas ou no raciocínio moral do consumidor pode não ser a estratégia mais eficiente para alavancar a venda de produtos "verdes”, se o consumidor julgar que tal “compra ecológica” não lhe traz nenhum benefício direto. Da mesma forma, considerar a decisão de compra como sendo um comportamento puramente econômico pode ser contra-produtivo, já que isto pode mitigar a motivação intrínseca das pessoas, levando o comportamento ambiental ao nível mais baixo exigido, e tornando-o dependente de fiscalização rigorosa.

Nyborg (1999), por sua vez, sugere que motivação pela moral ambiental e o conceito de motivação intrínseca são coisas ligeiramente diferentes, porque decisões morais requerem consciência das conseqüências e a atribuição de responsabilidade, o que não é o caso da motivação intrínseca. Conseqüentemente, os consumidores podem comportar-se moralmente mesmo se não estiverem intrinsecamente 
motivados. Nas palavras de Nyborg (1999: 420), “[as pessoas] não têm motivação intrínseca para separar o lixo doméstico” ${ }^{30}$.

A ausência de uma ligação clara entre intervenções externas (mecanismos econômicos, incluindo incentivos e punições) e metas específicas que os consumidores são capazes de compreender facilmente pode inibir a motivação intrínseca. O mesmo pode acontecer se os consumidores perceberem que seu comportamento responsável está sendo explorado por outras pessoas. Conforme argumentado por Thøgersen (1999: 440),

É condição necessária para a difusão do raciocínio da moral ambiental nas decisões de compra que características que conectam a compra a problemas ambientais fiquem salientes na situação de compra.

O raciocínio seguido por Thøgersen é o de que não é óbvio que as decisões de compra, tipicamente conduzidas numa perspectiva econômica, sejam influenciadas por aspectos morais, apesar de haver indícios de que isso possa acontecer. Para que isso ocorresse, argumenta Thøgersen, seria necessário que características que conectem o ato de compra a um determinado problema ambiental se tornassem salientes na situação de compra, desde que outros aspectos envolvidos na compra não fossem altamente envolventes (como a fidelidade a uma marca) a ponto de “monopolizar” a atenção do consumidor. Mesmo assim, para que a compra fosse influenciada por esses aspectos morais, a preocupação com o meio natural deve ser elevada.

Thøgersen (1999), em sua pesquisa, procurou verificar se essas duas condições - grande preocupação com o ambiente e ausência de outros fatores que sejam altamente envolventes - são necessárias e suficientes para ter impacto sobre as decisões de compra. Para elucidar essa questão, o autor estudou a escolha ${ }^{31}$, por parte de um grupo de consumidores dinamarqueses, por embalagens ambientalmente

\footnotetext{
${ }^{30}$ Mathios (1999: 432) questiona a própria idéia de motivação intrínseca, argumentando que "Mais do que compreender o comportamento ambiental com base na psicologia social e na motivação intrínseca, tal comportamento pode ser visto simplesmente como uma reação ao fato de que o preço da poluição por unidade consumida tem ficado cada vez mais baixo, aumentando com isso a demanda por itens poluidores".

${ }^{31}$ Para Thøgersen, a escolha por uma embalagem se dá quando um mesmo produto é oferecido em embalagens alternativas, com conseqüências econômicas mínimas.
} 
“mais amigáveis”. De acordo com Thøgersen, grande parte da população da Dinamarca está ciente dos problemas ambientais, e acha que pode contribuir para minimizá-lo - mesmo que seja alterando seus hábitos de consumo.

Para o acadêmico dinamarquês, muitos estudos empíricos sustentam que as atitudes "verdes" relacionadas com o comportamento do consumidor têm fundamento moral, mas trazem como limitação o fato de se concentrarem no comportamento pós-compra, sendo raras as pesquisas que buscam identificar a influência dessas preocupações morais sobre o ato de compra. Por isso, o comportamento observado no estudo que ele conduziu foi a propensão do consumidor em evitar, no ato da compra, a geração de lixo composto por embalagens.

A conclusão de Thøgersen é que, quando as duas condições expostas acima estão presentes, aspectos morais podem se sobrepor a fatores puramente econômicos nas decisões de compra “verdes”. Segundo o autor, isso demonstra que é preciso reforçar a motivação intrínseca dos consumidores para agir de forma ambientalmente “mais amigável”. Esta saliência indicada por Thøgersen, contudo, apesar de necessária para influenciar moralmente a compra, dificilmente será suficiente (Frey, 1999). No caso específico de embalagens, pode ser um obstáculo ao desenvolvimento de comportamentos mais "verdes" a incapacidade de parte dos consumidores para identificar as melhores alternativas em termos ambientais.

Outra fonte teórica importante de ser considerada quando se fala de comportamento “verde” do consumidor é a Teoria de Comportamento Planejado de Ajzen (TCP), aqui retratada da maneira como foi utilizada por Kalafatis et al. (1999). Esse arcabouço teórico, que procura entender como a comparação de produtos e marcas alternativas por parte do consumidor pode se traduzir em decisão de compra, tem sua origem em estudos da psicologia social sobre a formação de atitudes, e é influenciado pelos chamados modelos de expectativa de valor, cuja origem remonta a década de $1960^{32}$. Os modelos de expectativa de valor, por sua vez, demonstram a

\footnotetext{
${ }^{32}$ FISHBEIN, M. (1963). An investigation of the relationships between reliefs about an object and the attitude toward that object. Human Relations, Vol. 16, August, pp. 233-40, citado por Kalafatis et al. (1999)
} 
ligação entre critérios de avaliação e o conceito de atitude, e mostram que a expectativa de que um dado produto desempenhe determinadas funções e atenda certas necessidades trazem uma satisfação antecipada com esse produto, que culmina com o ato de compra.

De acordo com a TCP, a intenção é determinada por atitudes a respeito do comportamento esperado (determinada pela soma dos resultados esperados), normas subjetivas (baseadas nas crenças normativas sobre se determinadas pessoas que servem como referência para o indivíduo acham que se deve ter o comportamento em questão - em outras palavras, são o controle subjetivo imposto pelo desejo do indivíduo de agir de acordo com o que os outros esperam dele) e pela percepção de controle sobre o comportamento (a percepção do indivíduo de que pode efetivamente realizar a ação).

Sendo assim, a intenção que um indivíduo pode desenvolver para se comportar de uma certa maneira é determinada por suas atitudes pessoais em relação a esse tipo comportamento, pelo desejo de estar de acordo com as expectativas alheias a respeito de como agir, e pela percepção de que a ação é factível. Os resultados do estudo de Kalafatis et al. (1999) indicam que as influências sociais têm papel central na determinação de comportamentos mais “verdes” por parte dos consumidores.

Na opinião de Stern (1999), há três domínios em que o indivíduo se baseia para ter um comportamento mais "verde". O primeiro é o pessoal, que compreende os valores, crenças e normas subjetivas, que interagem e afetam os níveis de apoio do indivíduo a objetivos sociais em geral, e a ações em favor do ambiente em particular. Isso significa que, para apoiar uma ação de interesse da coletividade, o indivíduo precisa compartilhar de alguns dos valores-chave implicados na ação, além de acreditar que sua contribuição terá resultados concretos. Esse raciocínio difere da TCP, que se baseia na lógica da utilidade esperada, porque reconhece que o comportamento individual pode basear-se em valores altruísticos.

O segundo domínio é o comportamental. De acordo com esse acadêmico, há diversos comportamentos individuais que podem afetar o ambiente, tais como o “ativismo engajado”, os “comportamentos cidadãos”, o “apoio a políticas ambientais” e “ações individuais” (inclusive o comportamento de compra). Stern 
argumenta que esse último grupo de comportamentos é altamente situacional, e depende fortemente do contexto para ser alavancado.

Por isso, o terceiro domínio apontado por Stern é o contextual, também chamado por ele de estrutural. Entre muitos fatores, essa dimensão compreende atributos, como repertório cultural e religioso do indivíduo, além de variáveis situacionais, como local de residência e situação sócio-econômica. Cada indivíduo é afetado de forma única por um grupo de fatores diferentes, e quanto mais fortes forem os fatores contextuais, menos importância terão os valores do domínio pessoal.

2.7.2 - Repetição e Aprendizagem: Apontado o descompasso existente entre intenção e comportamento de compra, quando se trata de produtos “verdes”, está claro que há um elo ausente, capaz de eliminar essa incongruência. Foi sugerido na seção anterior que este elemento é a motivação - intrínseca e extrínseca. Para entender como a motivação poderia ser capaz de reduzir essa inconsistência comportamental, entretanto, é preciso entrar em outros aspectos teóricos.

De acordo com Chisnall (1995), quando se analisa o comportamento humano devem ser levados em consideração três conceitos básicos: cognição, percepções e processos de aprendizagem. Segundo a definição do acadêmico, cognição "refere-se aos processos mentais de conhecer, perceber e julgar que possibilitam às pessoas interpretar o mundo ao seu redor” (p. 23), o que provavelmente afeta os hábitos de consumo. Percepção, por sua vez, é definida por Chisnall como sendo o resultado da estimulação dos sentidos, e como tendo papel central no processo cognitivo. Para ele, a percepção é influenciada pela experiência passada do indivíduo, bem como por suas crenças e atitudes. Por fim, esse autor coloca que, através de um processo de aprendizagem (em que se avaliam experiências anteriores), o consumidor desenvolve atitudes - favoráveis ou desfavoráveis. Ou, em suas palavras, “[a]prendizagem (...) envolve mudanças relativamente permanentes no comportamento, que resultam de experiência, insight e prática” (p. 31).

Há diferentes modelos teóricos para os processos de aprendizagem, que Chisnall (1995) agrupou em duas escolas principais de pensamento: a conectivista e 
a cognitiva. Pelo que postula a primeira, aprendizagem se dá por associações entre estímulo e resposta, e percepção e insight têm pouca relevância. Dessa forma, podese desenvolver um comportamento (resposta) a partir da exposição de um indivíduo a determinado estímulo. Contudo, a exposição a um estímulo acima de determinado nível pode reduzir - e até extinguir - o seu impacto.

Talvez o mais conhecido autor que pode ser incluído nessa escola seja o behaviorista Skinner (1974), que introduziu a idéia de condicionamento operante. Esse conceito difere da associação clássica entre estímulo e resposta porque nenhum estímulo natural ou não aprendido é introduzido para iniciar a resposta. Ao contrário, respostas não solicitadas emitidas podem ser reforçadas (ou colocadas em extinção). No condicionamento operante, há um esforço voluntário na busca da resposta esperada, com a expectativa de se suprir algum estado de carência (Skinner, 1974). Resumidamente, o que Skinner defendia era que o comportamento humano poderia ser tratado como uma ciência, e que as ações do ser humano eram baseadas em experiências passadas (repertório mínimo básico). Dessa forma, descobrindo-se as variáveis que influenciam determinado tipo de comportamento, tornar-se-ía possível ter um certo grau de previsibilidade sobre as ações humanas. Um determinado comportamento poderia ser reforçado ou colocado em extinção, conforme o que se esperasse do indivíduo.

Os autores da escola cognitiva, por outro lado, enxergam a aprendizagem como sendo "um processo de reestruturação das cognições de um indivíduo relacionadas a problemas específicos” (Chisnall, 1995: 34). Para os autores que seguem essa linha, a informação obtida de forma deliberada ou incidental pode ser assimilada e armazenada com outras experiências passadas, num processo que auxilia os indivíduos na formação de suas atitudes. Em algum ponto futuro, essas informações processadas podem ser recuperadas na memória, e acabam por influenciar o comportamento.

As teorias cognitivas de aprendizagem consideram os indivíduos como solucionadores ativos de problemas que são afetados pelo ambiente em que vivem. Essas teorias mantêm estreita relação com o conceito de Gestalt (Chisnall, 1995), termo usado para indicar que a percepção de um objeto envolve uma avaliação 
holística de sua natureza. Quando se trata de comportamento do consumidor sob a perspectiva cognitiva, portanto, entende-se que o processo de compra envolve a avaliação de todos os fatores ambientais envolvidos.

Pela lógica da solução de problemas, de acordo com Engel et al. (1994), o processo decisório do consumidor segue os seguintes passos:

1) Reconhecimento da necessidade;

2) Busca por informações;

3) Avaliação pré-compra de alternativas;

4) Compra;

5) Consumo;

6) Avaliação pós-compra das alternativas; e

7) Descarte do produto não consumido ou de seus resíduos.

O presente trabalho apóia-se nos achados de Wagner (1997), que centrou sua análise nos conceitos de "saber” e “aprender” relacionados ao comportamento "verde" do consumidor, abordando o tópico de uma perspectiva cognitiva. Os pontos principais estudados por Wagner referem-se à forma com que os consumidores entendem produtos "verdes”, a que tipo de informação eles prestam atenção, e como o "aprender" afeta a escolha de produtos com o passar do tempo. Usando um Modelo de Escolha - em que o consumidor é visto como um processador de informação que coleta e avalia subjetivamente a informação (que é percebida como sendo relevante) para resolver um problema de compra - Wagner enfatiza a importância dos processos de busca de informação - interno (memória) e externo (fontes outras que não a memória) - e de regras de escolha.

A idéia de que conceitos importados da psicologia social são úteis para compreender o comportamento do consumidor não é nova. Katona (1995 [1953]), com seu texto clássico Comportamento Racional e Comportamento Econômico, foi um dos primeiros a desafiar as idéias de racionalidade e de maximização de utilidade (da forma que estas são entendidas na economia neoclássica). Katona mostrou as diferenças entre aprendizagem associativa (cujo princípio básico é repetição-reforço) e solução de problema através de raciocínio (um processo que envolve compreensão, deliberação, consideração de conseqüências e escolha), para concluir que o último é 
uma ocorrência relativamente rara que resulta em ações novas, e não repetitivas. Então, pode-se dizer, usando-se o raciocínio desse autor, que a solução de problemas é um desvio do comportamento habitual (em que as pessoas tendem a agir de forma similar àquela com que agiram em circunstâncias semelhantes - nesse caso, não há espaço para deliberação e escolha) ${ }^{33}$. Ou, para retornar a Chisnall (1995), é preciso que se quebre o ciclo de respostas habituais, que faz com que os indivíduos se adaptem aos estímulos, reduzindo o seu nível de percepção.

Dito isso, chega-se à proposição de que, para adotar conscientemente hábitos de consumo ecologicamente “mais responsáveis”, os consumidores precisam estar expostos a um problema novo (como, por exemplo, a necessidade de descartar diferentes materiais de embalagem separadamente) capaz de retirá-los do comportamento inercial (Morgan, 2000) característico das compras repetitivas feitas com baixo envolvimento - um Comportamento de Resposta Rotineira. Obviamente, os consumidores também podem ser levados a comprar produtos ambientalmente mais amigáveis mesmo em recompras habituais, bastando para isso que todas as marcas em seu repertório de consideração tornem-se “mais verdes”. Neste caso, contudo, a mudança não se dá por iniciativa do consumidor.

Na ocorrência de comportamentos baseados em solução de problemas, por outro lado, há um processo de aprendizagem subseqüente no qual contexto tem papel importante (Belk, 1995 [1975]; Wagner, 1997). A forma com que um problema é formulado e estruturado depende de um “contexto subjetivamente percebido e construído” (Wagner, 1997: 202), o que conseqüentemente influencia sua solução. Relacionadas ao contexto no qual consumidores formulam e resolvem seus problemas de compra estão numerosas variáveis, que vão de restrições orçamentárias a aspectos psicológicos.

Nessa linha, Stern (1999) enxerga a informação atuando sobre o domínio pessoal, e os incentivos sobre o domínio contextual. Isso explicaria por que programas de divulgação de informação têm efeitos restritos sobre o comportamento

\footnotetext{
${ }^{33}$ O processo de simplificação causado por decisões repetitivas também foi destacado por Howard e Sheth (1995 [1967]), que sugeriram a terminologia hoje difundida nas teorias de comportamento de compra: Solução Extensiva de Problema, Solução Limitada de Problema e Comportamento de Resposta Rotineira.
} 
ambiental quando há barreiras estruturais como pouca conveniência ou custos financeiros significativos. Por isso, esse autor atribui importância aos incentivos, não necessariamente monetários (a conveniência, por exemplo). Stern explica, contudo, que quando os incentivos são suficientemente atraentes, torna-se mais eficiente investir em informação do que elevar os incentivos.

2.7.3 - O Papel da informação: Considerando-se os propósitos do estudo e a sua opção por uma abordagem cognitiva, o tipo de informação disponibilizada aos consumidores passa a assumir papel importante no processo de motivação de um comportamento "mais ecológico" por parte do consumidor. Com isso, a possibilidade de que se desenvolva, no Brasil, um contexto favorável à difusão de discussões relacionadas com a proteção ambiental e com o impacto que as embalagens podem ter no meio natural, reforça-se a importância de se saber em que extensão as empresas estão considerando o comportamento "verde” do consumidor em suas decisões de embalagens.

O acesso à informação, por sua vez, não é suficiente para impedir que os consumidores façam escolhas “erradas”34. A qualidade da informação e a maneira como essa é processada são fundamentais. No caso de ausência de informação, entretanto, os consumidores podem ser levados confiar no bom senso para tomar suas decisões, o que pode fazer com que os processos decisórios sejam baseados em estereótipos - ou “estruturas prototípicas de conhecimento” (Wagner, 1997) ${ }^{35}$.

Assumindo-se, portanto, a perspectiva de que a solução de problemas é dependente do contexto e obedece uma lógica cognitiva, segue-se que os aspectos experienciais de consumo (Holbrook e Hirschman, 1995 [1982]) também devem ser

\footnotetext{
${ }^{34} \mathrm{O}$ impacto ambiental de cada embalagem pode ser medido após uma análise completa do seu Ciclo de Vida. A ACV (Análise do Ciclo de Vida), entretanto, é muito complexa, e o poder público, a indústria e outros grupose de interesse ainda estão brigando para chegar a um consenso sobre as implicações de cada material de embalagem para o meio (Levy, 2000). Para que se tenha uma idéia de quão complexa é a questão, ainda não se sabe ao certo se as embalagens retornáveis são menos danosas do que suas substitutas descartáveis (Levy, 2000), ainda que essa seja a percepção dos consumidores (Thøgersen, 1999).

35 Thøgersen (1999), em seus estudos sobre o comportamento ético relacionado à escolha de embalagens, percebeu que as embalagens escolhidas por serem 'mais ecológicas' não necessariamente o eram - mas assim o senso comum as considerava.
} 
levados em conta. Isso traz, naturalmente, para a discussão a importância das marcas - especialmente quando se analisa o mercado de cervejas, onde as escolhas dos consumidores são fortemente influenciadas pelas marcas (Mintel, 2001b). Como a marca é um instrumento através do qual se podem transmitir valores (Aaker, 1996; Elliott \& Wattanasuwan,1998; Kapferer, 1997), há que se verificar, no estudo exploratório que se seguirá, se o posicionamento atual das marcas de cerveja vendidas no Brasil reforça associações que remetem a valores de preservação ambiental. 


\section{CAPÍTULO 3: ESTUDOS DE CASO}

Após a revisão da bibliografia sobre os temas que fundamentam esta dissertação, cabe apresentar e analisar os resultados obtidos nas entrevistas, conduzidas de forma a levantar qual a atenção que as empresas que foram investigadas neste estudo estão dando, atualmente, ao marketing "verde" e ao comportamento "verde" do consumidor. Com isso, esperava-se identificar fundamentalmente o impacto que tais temas podem estar tendo sobre as escolhas de embalagens das cervejarias, e como, se for o caso, cada empresa está se preparando para atender às demandas ecológicas de seus consumidores.

As entrevistas também permitiram investigar como essas empresas enxergam o comportamento do consumidor, e como estão analisando fatores contextuais referentes ao meio ambiente, aspectos que se refletem nos seus esforços de marketing e, de uma forma mais profunda, na maneira com que estão se estruturando para lidar com essas questões. Para apresentar os resultados das entrevistas, optou-se por realizar um breve resumo de como a embalagem se insere no dia a dia de cada cervejaria estudada, incluindo-se aí a análise do processo de tomada de decisão sobre o assunto e o entendimento do papel da embalagem nas estratégias de posicionamento de marketing.

Com base nas informações levantadas, então, os casos serão analisados em função de como cada empresa está, hoje, encarando os desafios impostos pelo consumerismo "verde” e pelo maior rigor da legislação ambiental que se delineia. Dessa forma, torna-se possível avaliar como as cervejarias que compõem este estudo estão - se é que estão - se estruturando para orientar suas práticas de negócios na direção do desenvolvimento sustentável. 


\section{1 - Cervejarias Kaiser (Molson)}

A Cervejarias Kaiser surgiu no início da década de 1980 pelas mãos de Luiz Otávio Possas Gonçalves. O grupo do qual o executivo era um dos principais acionistas possuía duas engarrafadoras da Coca-Cola em Minas Gerais, e estava tendo queda nas vendas de refrigerantes, por causa de ações de "vendas casadas”36 feitas por Brahma e Antarctica. Como estratégia para combater isso, e observando o grande potencial do mercado brasileiro de cervejas, Gonçalves decidiu criar a Kaiser.

A primeira unidade da nova cervejaria foi em Divinópolis $(\mathrm{MG})^{37}$, uma fábrica que, segundo a empresa, inovava em relação às existentes até então por utilizar um processo de maturação e fermentação em tanques fechados, sem interferência ambiental. Esse método reduzia em 30\% o consumo de energia e mão-de-obra. A cerveja Kaiser Pilsen foi lançada em 22 de abril de 1982.

Em 1984, a Coca-Cola Internacional adquiriu 10\% da Cervejarias Kaiser. Em 2003, a cervejaria canadense Molson, que já havia comprado a marca Bavária (vendida pela AmBev por exigência do CADE - Conselho Administrativo de Defesa Econômica), adquiriu o controle da Kaiser.

Nesta dissertação foi analisada a entrevista concedida por Roberto Garcia, Coordenador de Tecnologia de Embalagens, que trabalha na unidade de Jacareí (SP) da Kaiser, e cuja função na empresa é dar suporte técnico ao pessoal de marketing no desenvolvimento de novas embalagens. Ele participa ativamente do processo de tomada de decisão sobre embalagens, mas normalmente recebe o briefing pronto da área de marketing - mesmo quando se trata de desenvolvimento de projetos internos da empresa. A decisão não passa pela área de marketing apenas quando for algo simples, para obedecer alguma legislação específica. Nestas ocasiões, a área técnica só informa ao marketing, através do departamento jurídico, que há uma nova legislação, e faz todas as alterações necessárias. Recentemente, por exemplo, por

\footnotetext{
${ }^{36}$ Venda casada é uma prática de negócios pela qual o fabricante de cerveja exigia exclusividade na venda de refrigerantes, fazendo com que o ponto-de-dose tivesse apenas produtos da mesma marca.

${ }^{37}$ Hoje a empresa possui dez unidades. Além da fábrica de Divinópolis, há plantas em Mogi-Mirim (SP), Nova Iguaçu (RJ), Jacareí (SP), Gravataí (RS), Araraquara (SP), Feira de Santana (BA), Pacatuba (CE), Ponta Grossa (PR) e Queimados (RJ) (Kaiser, 2003).
} 
uma determinação do Conar, todas as cervejarias foram informadas que precisam colocar, até novembro de 2003, a informação "Venda proibida para menores de 18 anos” em suas embalagens. Nesse caso, segundo Garcia, “Ao departamento de marketing só resta dar um OK, porque é uma exigência, e já vem tudo especificado a que distância da base do rótulo deve ser inserida a informação, tamanho das letras etc.”.

Por ter pleno acesso às informações levantadas pelo departamento de marketing, esse profissional está a par de todos os fatores que influenciam as decisões sobre embalagens na cervejaria. Isso fez dele uma fonte muito apropriada para os objetivos da presente pesquisa.

As marcas de cerveja que a Molson administra no Brasil, através da Cervejarias Kaiser, são a Kaiser (Pilsen, Bock e Summer), a Bavária (Pilsen, Premium, Sem Álcool e Exportação), a Xingu, a Palma Loca (para exportação) e a Santa Cerva, portfólio que dá à empresa cerca de $10 \%$ de participação no mercado brasileiro de cervejas. A Kaiser é responsável também pela fabricação e envase da Heineken no Brasil. Para essas marcas, a empresa trabalha com garrafas retornáveis de vidro de $600 \mathrm{ml}$, garrafas de vidro descartáveis tipo long neck de 355ml, garrafas de vidro de 300ml retornáveis (em locais muito específicos - até pouco tempo atrás, por exemplo, essa embalagem, conhecida como "Extra” ou "bojudinha”, era usada no Maracanã) e a lata de alumínio de 350ml. Hoje, a Kaiser não trabalha mais com latas de aço, que foram usadas até o ano passado pelas unidades de Pacatuba e Feira de Santana, projeto que foi descontinuado por questões comerciais.

No caso da Kaiser, a participação de cada tipo de embalagem difere um pouco da média do mercado. A garrafa retornável de vidro de $600 \mathrm{ml}$ responde por pouco menos que $60 \%$, a long neck tem cerca de $2 \%$, e a lata de alumínio aproximadamente $38 \%$ do mix de embalagens da empresa.

$\mathrm{Na}$ Kaiser, para que se decida sobre as embalagens de cerveja, são feitas pesquisas de mercado. Qualquer mudança, contudo, é analisada em termos do seu impacto sobre a qualidade do produto. “A adequação da embalagem vem mais ou menos no vácuo de quesitos técnicos.” Isso porque o mercado de cervejas é comoditizado, como coloca Garcia. 
A cerveja não tem valor agregado. Você vende uma garrafinha long neck a $R$ \$ 1,20, uma garrafa de $600 \mathrm{ml}$ gelada, no boteco, a R $\$ 2,00$, e uma latinha no supermercado a $\mathrm{R} \$ 0,80, \mathrm{R}$ \$ 0,60 - você acha até por $\mathrm{R}$ \$ 0,48. É muito difícil mexer em embalagens, por causa dos impactos no custo final do produto.

Para gerar margens melhores, a empresa aposta na garrafa de vidro retornável de 600ml. Isso, de certa forma, é uma direção do mercado que a Kaiser está procurando seguir. Esse tipo de embalagem acaba se restringindo a canais como bares e restaurantes, em virtude da grande resistência das redes de varejo em trabalharem com esse tipo de vasilhame. Na Kaiser, contudo, acredita-se que há possibilidades concretas de que a garrafa de vidro retornável volte aos supermercados, principalmente nos quiosques externos das grandes lojas.

As garrafas de vidro long neck, na Kaiser, são usadas como ferramenta de posicionamento capaz de agregar imagem de marca e viabilizar margens maiores para a empresa. "Pelo preço da embalagem, nada justifica que a garrafa long neck chegue ao consumidor por um preço superior ao da lata. É tudo uma questão de posicionamento”, confirma Garcia. Mas a maior força desse tipo de embalagem é o chamado mercado frio - bares, casas noturnas, restaurantes (especialmente os mais sofisticados), lojas de conveniência e outros pontos-de-venda em que a cerveja já é vendida gelada.

A Kaiser declara não ter projetos para recorrer, no curto prazo, às stubbies, garrafas de vidro de 200ml. A empresa, contudo, não descarta completamente essa possibilidade, mas enfatiza que, se houver mercado para essas embalagens, é apenas um nicho, o que é pouco atraente no momento em que a Kaiser está interessada em recuperar margens. "Há projetos em garrafas de 200ml, 250ml. É uma iniciativa da indústria vidreira para reduzir o custo da garrafa. Mas quando você analisa uma nova embalagem, não dá para considerar só o custo da garrafa. Quando você diminui muito a embalagem, diminui o custo da garrafa, mas aumenta o custo variável. Aí é questão de a empresa querer pagar por isso.”

A lata, na visão da empresa, leva vantagem sobre as garrafas quando o assunto é conveniência. "O consumidor sente que é uma comodidade para ele.” Por isso, a lata também é dirigida ao mercado frio - mas tem menor penetração do que a long 
neck quando o consumidor busca status. Nas grandes redes de supermercado, em contrapartida, a lata tem maior presença do que as garrafas long neck. Porém, com esse tipo de embalagem, a empresa tem uma margem muito pequena. A lata de aço, por ser mais barata que a de alumínio, pode dar um retorno melhor para a cervejaria.

Com relação a aspectos técnicos, aço e alumínio têm prós e contras. Na visão da Kaiser, a lata de aço é muito boa para ser usada em regiões como o nordeste brasileiro, porque é mais resistente que a de alumínio. Por isso a empresa investiu há um tempo nesse tipo de embalagem para aquela região, movimento hoje seguido pela AmBev. Só que esse ponto forte da lata de aço é, também, na análise da Kaiser, o seu ponto mais fraco. Isso porque a lata é tão resistente que não se rompe, o que acaba prejudicando a aparência da embalagem. Garcia explica que

O mercado do nordeste maltrata muito a lata, pelas condições das rodovias e pelas condições de manuseio. Lá o pessoal ainda usa gelo e sal para gelar bebida. E isso tudo ataca muito o visual da lata. Como a oxidação do aço é amarela, e não branca como a do alumínio, a lata fica horrível. Isso agride muito o visual.

Há, também, na avaliação da Kaiser, uma certa “restrição” do consumidor do nordeste com relação à lata de aço, por causa de experiências passadas de acondicionamento no material. O consumidor, por falta de informação, acaba transferindo problemas que teve há algum tempo para situações presentes. Garcia relata comentários existentes na região de que a AmBev teria tido, no passado, um problema com sua cerveja no nordeste, ao utilizar na fabricação do produto uma água mais salobra, que mudava o gosto da cerveja. “O consumidor associou isso à lata de aço”, o que teria gerado resistência ao material. Segundo pesquisas da Kaiser, o consumidor percebe quando a lata é de aço. Ele sabe diferenciá-la da de alumínio, porque o aço, quando comparado ao metal concorrente, é mais pesado, mais escuro, tem menos brilho e, dependendo do tipo de arte que se usa na lata, requer tintas mais opacas para sua decoração.

Quando o consumidor pega a lata de aço, ele diz que é como estar chupando uma barra de ferro. Às vezes, a lata nem está oxidada, mas o consumidor diz que a cerveja está oxidada, está com um gosto metálico, de aço. E isso não é opinião minha. Eu vou ao 
supermercado, falo com a pessoa na gôndola. Em Recife, por exemplo, a Kaiser teve, por um tempo, latas de alumínio e aço misturadas na gôndola. O consumidor, quando percebia, pegava só a de alumínio. Os demais produtos em lata eram todos em alumínio, pois na região de Recife não tem lata de aço - há uma planta da Latasa lá. Então, o consumidor consegue pegar a diferença. O próprio catador de lata percebe isso. Ele deixa a lata de aço no chão, pelo preço pago pela matéria-prima. O alumínio paga bem mais.

A Metalic está trabalhando para reverter o problema na reciclagem, subsidiando o preço da sucata e divulgando para o consumidor final a reciclagem da lata de aço. A questão da aparência, contudo, é mais complicada de se resolver.

Com relação ao acondicionamento de cerveja em garrafas plásticas, a Kaiser não se mostrou propensa a adotar tal solução. Lembrando que esse tipo de embalagem só está sendo usada por um fabricante no Brasil (a Cerpa, que trabalha com uma garrafa retornável de PEN, com capacidade para 300ml), o profissional da Kaiser explicou que, até o momento, o plástico não superou todos os obstáculos mercadológicos para se firmar como alternativa viável.

A gente não entendeu nada até agora. A garrafa [da Cerpa] é retornável e vai da Escandinávia para a Alemanha, onde são colocadas em garrafeiras que foram injetadas lá, e daí são enviadas para o Brasil. A rolha vem do Japão. Até o rótulo parece que é importado. Cada garrafinha está sendo vendida por cerca de $\mathrm{R} \$ 2,50$. As informações que nos chegaram eram de que a Cerpa estaria utilizando essa garrafa para substituir a lata. Eu acho que no mercado brasileiro não pega. É a mesma coisa que perguntar se o consumidor gosta de tomar chope em copo plástico. Um cervejeiro experiente tem ojeriza de cerveja em plástico.

Quando a idéia de acondicionar cerveja em plástico chegou ao Brasil, há seis ou sete anos, a área de marketing da Kaiser analisou bastante a alternativa. Falava-se na viabilidade da tecnologia, mas na época "era tudo balão de ensaio”, como define Garcia. A tecnologia, entretanto, avançou muito desde então. Os requisitos dos cervejeiros para avaliar esse tipo de embalagem também foram diminuindo. Se antes, por exemplo, exigia-se um shelf life de 6 meses, hoje já se aceitam 4 meses para poder tentar lançar o produto. Todas as cervejarias avaliaram, e estão avaliando, a viabilidade das novas tecnologias. A Kaiser analisou soluções de diferentes fornecedores, mas não há perspectivas de lançamento de cerveja da empresa em garrafa plástica. O problema não é mais técnico, mas puramente mercadológico. 
Hoje, os sistemas de fechamento são muito similares aos usados em garrafas de vidro. O enchimento a quente é viável, pois há garrafas que agüentam o processo de pasteurização, e existem linhas de flash pasteurização (a cerveja é pasteurizada antes do envase) que viabilizariam a adoção de garrafas plásticas. Hoje também já existem adesivos que permitem a rotulagem de embalagens de PET ou PEN. Os maiores problemas, na avaliação da Kaiser, são a necessidade de se investir nas linhas para fazer as alterações necessárias e o maior preço da garrafa plástica em relação às outras alternativas.

Garcia relatou que, na região de Campinas, há gente envasando cerveja em PET, com distribuição em circuito refrigerado. "Se a cerveja ficar fora da geladeira uma semana, a garrafa pode explodir na sua cara”. Nesse caso específico, perde-se na qualidade do produto, e o prazo de validade é muito curto. Isso porque, quando se fala em garrafa de cerveja adequada, está-se falando em barreiras. Dependendo do tipo de barreira que se necessita, portanto, varia o preço da garrafa plástica. Na Kaiser, acredita-se que cervejarias como a AmBev e a Schincariol, que possuem linhas de refrigerante, têm condições de lançar cerveja em PET com investimentos menores que a Kaiser, que só faz cerveja, pois essas empresas já têm linhas preparadas para trabalhar com PET.

Eu acho que um está esperando o outro lançar para ver se vai ou não atrás. A experiência da Coca-Cola com refrigerantes não foi das melhores. Ela deu um tiro no pé ao lançar a Coca em PET. As marcas regionais cresceram muito, e hoje a Coca-Cola começa um retorno ao vidro, com garrafas retornáveis. A logística reversa é um diferencial competitivo da Coca-Cola.

Como dificuldade adicional para as embalagens plásticas para cerveja, a Kaiser inclui a questão da logística reversa. Mais uma vez referindo-se ao exemplo da Cerpa, Garcia afirmou, por exemplo, que "se uma daquelas garrafas desce [para outras regiões do Brasil], não sobe mais”.

Do que foi colocado acima, observa-se que os fatores que influenciam as decisões sobre embalagem na Kaiser são, primordialmente, custos, aspectos técnicos e, evidentemente, a preferência do consumidor, sendo os dois primeiros fatores de restrição. A embalagem é usada pela empresa como ferramenta importante no 
posicionamento de suas diferentes marcas. "Principalmente se você for analisar um portfólio de marcas. Trabalhando só com uma marca, como a Kaiser fazia há algum tempo, daí fica difícil.” Garcia relata, por exemplo, que quando a Molson adquiriu a Kaiser, a Bavária Premium tinha uma garrafa exclusiva de 355ml. Foi feita uma pesquisa de mercado para reposicionar essa marca mais próximo da sua concorrente principal, a Bohemia (da AmBev). Para isso, foi alterado o produto, que perdeu o amargor, e decidiu-se mexer nas embalagens. Foi dada ao consumidor uma opção de embalagem antes inexistente para esse produto, a garrafa retornável de $600 \mathrm{ml}^{38}$. Foram desenvolvidos novos rótulos, com cores metálicas, substituiu-se o foil de alumínio (que era importado) usado no gargalo por um rótulo de papel.

O consumidor de cerveja, para a Kaiser, é eminentemente masculino, mas seu perfil varia conforme a marca. Até por causa de exigências legais, a empresa procura posicionar seus produtos para consumidores maiores de 25 anos. Os valores de marca que se trabalham, apesar de diferirem um pouco de marca para marca, em geral são ligados a aspectos de imagem, de status, de sucesso. Não são consideradas no posicionamento das marcas da empresa, aparentemente, atitudes dos consumidores ligadas à preservação ambiental, o que sugere que a empresa ainda não considera esse ponto fundamental nas decisões de compra de seus consumidores.

Por outro lado, percebe-se pelos investimentos que a empresa tem feito na área da gestão ambiental que a Kaiser está bastante preocupada com o impacto que seu comportamento ambiental pode ter na imagem da empresa. A Kaiser investiu na formação de Especialistas Ambientais para cada uma de suas unidades, com o intuito de viabilizar a completa aplicação de um Sistema de Gestão Ambiental, e mantém investimentos constantes visando à preservação ambiental, como parte de uma política integrada única para meio ambiente, segurança e saúde dos seus funcionários e qualidade dos produtos. Em consonância com o que recomendam as discussões sobre o desenvolvimento sustentável, a Kaiser preocupa-se com a prevenção da poluição e com a redução dos impactos ambientais (no caso da Kaiser, especialmente com o consumo de água e com a geração de efluentes).

\footnotetext{
${ }^{38}$ Hoje, a Bavária Premium é encontrada tanto em garrafas long neck quanto em vasilhames retornáveis de $600 \mathrm{ml}$.
} 
Apesar de as embalagens não aparecerem diretamente como alvo de uma política ambiental específica, a dimensão “verde” é uma das componentes da argumentação da empresa em prol da maior presença da garrafa retornável de $600 \mathrm{ml}$ no mercado brasileiro. A Kaiser apóia, através do Sindicerv, projeto de lei que estabelece que no mínimo $80 \%$ das embalagens de cerveja sejam garrafas retornáveis.

Além de guiar a empresa no cumprimento de exigências legais, a política integrada da Kaiser contempla a análise das expectativas de diversos stakeholders, como colaboradores e as comunidades das regiões onde a empresa tem fábricas, visando à proposição de soluções que os satisfaçam. Isso demonstra que a empresa está preocupada com outras ações de responsabilidade social, um passo importante no caminho do desenvolvimento sustentável. Todas as unidades da Kaiser, por exemplo, possuem um Centro de Voluntariado Kaiser, que junta funcionários da empresa para fazer trabalho social na comunidade. Além de melhorar a imagem da empresa junto à comunidade, esse tipo de ação tem repercussão entre os funcionários. "Isso me dá orgulho”, chegou a afirmar Garcia durante a entrevista. A Kaiser foi, também, a primeira cervejaria brasileira a implantar um sistema de atendimento ao consumidor, e o KAC (Kaiser Atendimento ao Consumidor) é hoje ferramenta importante na estratégia da empresa de satisfazer os stakeholders.

A gente procura responder a todas as questões, por mais absurda que seja. Tudo que é referente a embalagens vem para mim. Sempre que possível eu convido os consumidores para virem até a fábrica, para conhecer o processo todo e daí explicar por que algumas das sugestões e críticas são descabidas.

O Sistema de Gestão Ambiental da Kaiser iniciou-se em 2000, com um diagnóstico da situação ambiental das unidades da empresa, tomando como referência a legislação ambiental vigente. Depois, a empresa procedeu a uma verificação da metodologia de gestão ambiental, e criou um "Rating Ambiental” uma ferramenta para avaliação do estágio de adequação ambiental de cada uma das unidades. Segundo informa a empresa, esse Rating Ambiental apresentou um 
crescimento de $76 \%$ desde que as primeiras medições foram feitas, em outubro de 2000.

\section{2 - AmBev}

A história da AmBev remonta ao século XIX. No ano de 1885, na cidade de São Paulo, surgiu a primeira fábrica da Antarctica Paulista - que se transformaria em Sociedade Anônima Antarctica e, na seqüência, em Companhia Antarctica Paulista. Três anos depois surgiria aquela que se tornou a maior rival da Antarctica por muitos anos, antes de com ela se fundir para formar a AmBev, passado pouco mais de um século: a Companhia Cervejaria Brahma, que nasceu Manufactura de Cerveja Brahma Villiger \& Companhia. Apesar de Antarctica e Brahma serem as companhias que originaram a AmBev, entretanto, a raiz mais antiga da empresa pode ser encontrada na cidade de Petrópolis, no Rio de Janeiro, onde em 1853 foi fundada a Cervejaria Bohemia. Essa fábrica, a mais antiga cervejaria do país, seria adquirida pela Antarctica em 1961.

Em 1999, a Companhia Antarctica Paulista e a Companhia Cervejaria Brahma comunicam ao mercado a sua fusão, que resultou na criação da AmBev - Companhia de Bebidas das Américas, aprovada pelos órgãos reguladores do Governo Brasileiro em março de 2000. Nascia, ali, a $5^{\text {a }}$ maior empresa de bebidas do mundo, dona de um gigantesco portfólio de marcas e com onze fábricas de cerveja espalhadas pelo Brasil. $^{39}$

Para esta dissertação, foi ouvida a Coordenadora de Desenvolvimento de Embalagem da AmBev, Camille Kaufmann, responsável pelo andamento dos projetos de embalagem - relacionados não apenas com cerveja, mas também com refrigerantes, bebidas isotônicas, chás e águas - na empresa.

Na AmBev, há um padrão corporativo de desenvolvimento de embalagens, que envolve diversas áreas. As idéias geradas pelo departamento de marketing são

\footnotetext{
39 Agudos (SP), Brasília (DF), Curitiba (PR), Estrela (RS), Goiania (GO), Guarulhos (SP), Jacareí (SP), Lages (SC), Montenegro (RS), Natal (RN) e São Luís (MA).
} 
discutidas com as áreas de suprimentos, logística, com o pessoal de vendas e com o pessoal da fábrica. Coordenando esse processo está a área em que trabalha a profissional entrevistada. O briefing para o desenvolvimento de novos produtos e de novas embalagens vem da área de marketing, e a partir daí é montada toda uma estrutura de desenvolvimento, que começa com testes iniciais e moldes piloto. Depois, vêm os testes industriais, de onde o projeto é encaminhado para um comitê técnico fazer a homologação da embalagem. Entre essas idas e vindas, o projeto pode levar alguns meses ou até anos, dependendo da evolução do desenvolvimento e da complexidade do projeto. No caso de garrafas de vidro, por exemplo, o desenvolvimento é mais lento, entre outras coisas, em função do tempo necessário para a fabricação dos moldes nas vidrarias, e dos ajustes necessários nas linhas de enchimento.

Por trás de todo novo projeto de embalagem da AmBev, porém, de acordo com a empresa, estão as preferências do consumidor.

\begin{abstract}
São muitas etapas que a gente tem que cumprir. Entre a idéia sair do marketing e a fabricação dos moldes, há uma série de etapas, de mock-ups que a gente tem de trazer para aprovação. A gente faz o desenho da embalagem junto com a área de marketing, desenvolve o design, depois volta para aprovação interna. A gente faz pesquisa com o consumidor, também. A AmBev tem também uma área de inteligência de mercado, que tem por premissa identificar quais são as necessidades do consumidor. Quando a gente identifica alguma necessidade dele, isso pode virar um projeto no futuro. Então, as fontes de informação são as necessidades do consumidor. Por exemplo, os últimos projetos desenvolvidos [Skol Beats, Bohemia Escura e Bohemia Weiss] surgiram de necessidades encontradas. Tudo tem muito estudo, muito embasamento técnico.
\end{abstract}

Em seus projetos de embalagem, a AmBev mostra-se inovadora, mas baseia-se em pesquisas intensas (não apenas com consumidores, mas também buscando benchmarks mundiais) e recorre a parceiros tecnológicos com experiência, de forma a minimizar os riscos inerentes a novos lançamentos. A AmBev, por exemplo, não usa protótipos. Apenas embalagens de linha de fornecedores consagrados.

Os tipos de embalagens para cerveja utilizados pela AmBev são os mesmos das demais cervejarias, com uma ou outra embalagem exclusiva sendo usada como ferramenta de reforço de marca. A empresa trabalha, fundamentalmente, com garrafas retornáveis de vidro de $600 \mathrm{ml}$, garrafas retornáveis de vidro de $300 \mathrm{ml}$, 
garrafas long neck de vidro de 355ml e latas (de aço e de alumínio) de 350ml. Há, além disso, embalagens exclusivas para o mercado brasileiro, como a garrafa com perfil curvilíneo da Skol Beats, e outros sistemas de embalagem desenvolvidos especialmente para mercados externos, como as garrafas de $970 \mathrm{ml}$, one-way e retornáveis, para a Argentina.

Apesar de não ter números disponíveis referentes à participação de cada material no mix de embalagens da AmBev, a coordenadora de desenvolvimento de embalagens da empresa acredita que não há razões para ser diferente da média de mercado.

A participação de cada material deve ser próxima do que é no mercado, porque a AmBev tem $70 \%$ do mercado. Por isso, o que nós temos deve puxar o mercado.

A AmBev, entretanto, recorre a diferentes tipos de embalagem para reforçar o posicionamento de cada marca. Por isso, nem todas as embalagens mencionadas acima estão disponíveis para todas as marcas da empresa, uma vez que cada sistema de embalagem é mais (ou menos) apropriado em diferentes canais e situações de consumo. As marcas - e as embalagens com que estas chegam ao mercado - que a AmBev mantém em seu portfólio são: Skol Pilsen (garrafa 600ml, lata 350ml, lata 473ml, long neck 355ml), Skol Beats (garrafa long neck 330ml com shape exclusivo), Brahma Chopp (garrafa 600ml, garrafa 300ml, long neck 355ml, lata 350ml), Brahma Extra (long neck 355ml), a recém-lançada Brahma Light (long Neck 355ml e lata 350ml), Brahma Malzbier (garrafa 600ml, long neck 355ml), Antarctica Malzbier (garrafa 600ml, long neck 355ml), Antarctica Original (garrafa 600ml), Antarctica Pilsen (garrafa 600ml, lata 350ml, long neck 355ml), Antarctica Pilsen Extra (long neck 355ml), Antarctica Pilsen Extra Cristal (long neck 355ml), Bohemia (garrafa 600ml, lata 350ml, long neck 355ml), Kronenbier (cerveja sem álcool, em lata 350ml e long neck 355ml), Caracu (garrafa 300ml, long neck 355ml, lata 350ml), Carlsberg (lata 350ml, long neck 355ml), Miller Genuine Draft (lata $350 \mathrm{ml}$, long neck 355ml), Polar Export (garrafa 600ml, long neck 355ml, lata 350ml) e Serra Malte (garrafa 600ml). 
A embalagem é muito importante para nós. A definição que eu mais gosto é de que ela é o "vendedor silencioso", que vende o produto sem falar nada. É isso que é importante. Tem que entregar o que está prometendo. Se você tem uma embalagem com a função de entregar nobreza, vamos procurar fazer um rótulo caprichado, uma rolha diferente, uma garrafa com um shape parecido com o de uma bebida mais nobre. A embalagem tem de ser simples, prática, barata quando entregar alguma coisa desse tipo, também. A embalagem contribui para o posicionamento de marca, sim. Nos últimos anos, a gente tem comunicado muita coisa através da embalagem. Não só a embalagem primária, mas a secundária, os shrinks. Com certeza, embalagem é tudo. Eu tenho que defender isso, mais do que ninguém. Em qualquer indústria, o produto é sempre muito valorizado. Mas eu acho que a embalagem tem crescido em importância. O pessoal vem falando mais da embalagem, e não só do produto.

Ainda com relação aos diferentes materiais, a AmBev não acredita estar havendo uma tendência favorável a algum de tipo específico de embalagem, seja em vidro, seja em lata. Isso é coerente com a posição da empresa a respeito da importância da embalagem nos processos de posicionamento de marca. O vidro, por ser bastante maleável, por exemplo, permite a criação de shapes diferenciados, possuindo características específicas para isso. A lata, por sua vez, mostra-se mais apropriada para a realização de ações promocionais, por exigir menos alterações nas linhas.

A lata é apropriada para ações como a do CD Pack [um 12-pack promocional de latas, mais um porta CD com um CD dentro, que foi distribuído em duas ações da Skol] neste ano. Depende muito do que você quer com a embalagem. Ação com embalagem de vidro é mais difícil, é complicado para a própria linha de produção. Para a área de embalagem, todos os desenvolvimentos - para qualquer produto, qualquer marca - têm a mesma importância. Então, o tipo de embalagem que vai ser desenvolvido depende do que você quer entregar.

Os três projetos especiais mencionados anteriormente - Skol Beats, Bohemia Escura e Bohemia Weiss - têm características de reforço de marca, segundo a AmBev. No caso das duas edições da Bohemia, por exemplo, são séries limitadas de produto, com volumes pequenos. Não são produtos de linha. Evidentemente, as ações especiais que buscam agregar valor não se restringem apenas à garrafa, e estendem-se a outros complementos: um formato diferenciado, um rótulo diferente, um foil, uma tampa diferente.

Por tudo isso, a AmBev prefere não priorizar nenhum tipo de embalagem, ao menos explicitamente. A empresa diz ter a política de entregar ao consumidor o que 
ele quer, no tipo de embalagem que ele considerar mais apropriado. Nessa linha, a empresa prefere não assumir incondicionalmente a posição do Sindicerv (ao qual é associada) de defender a embalagem retornável de 600ml, como forma de estimular as vendas e de recompor margens.

\begin{abstract}
A gente tem de atender o consumidor. A posição da AmBev é atender o consumidor, e estar presente no maior número de mercados, no maior número de pontos-de-venda. $\mathrm{O}$ vidro não é a solução para $100 \%$ dos casos. O que a AmBev quer é vender cada vez mais. Independente se é lata, long neck, garrafa retornável. O nosso negócio é produzir cerveja. Então, não tem nenhum tipo de bandeira sendo levantada para qualquer tipo de embalagem. Tem gente que gosta de tomar cerveja em lata porque é mais gelada, tem gente que gosta da long neck porque é mais legal de segurar. Então, a gente tem de ter um pouco de tudo, porque a gente quer é agradar o consumidor. Quando a gente lançou Brahma Light agora, a gente lançou em lata e long neck, boas embalagens para os canais frios. O importante é ter diversidade, para poder estar sempre vendendo a sua marca, agregando valor nas diferentes situações. A garrafa retornável precisa de toda uma logística reversa para se viabilizar.
\end{abstract}

A AmBev não declara, por considerar a informação estratégica, sua posição a respeito de novos tipos de embalagem, como a garrafa de PET, mas mostra-se satisfeita com as possibilidades oferecidas atualmente no mercado.

O mercado está muito consagrado do jeito que está. Dá para fazer muita inovação usando as embalagens que existem hoje. Vide o vidro, que a gente inventa uma coisa diferente da outra e dá super certo.

Com relação ao aço, contudo, a empresa manifesta uma postura diferente daquela expressa pela Kaiser.

Não percebemos diferenças, junto aos consumidores, entre as latas de aço e de alumínio. A gente não tem registros referentes a isso. Na verdade, o nordeste é uma região que não reclama muito. Os índices da SAC lá são muito mais baixos do que no sul. Então a gente não consegue perceber uma eventual insatisfação nesse sentido. É uma região do Brasil que não reclama muito. Dependendo do produto, a gente tem só em aço, só em alumínio, porque tem produto que é produzido numa única fábrica e distribuído para todo o país.

Uma vez que são os anseios do consumidor que direcionam os projetos de embalagem da AmBev, e que há monitoramento constante na empresa sobre o rumo dessas preferências, a postura da empresa com relação aos assuntos ligados ao meio ambiente é de extrema importância para a presente dissertação. O que se observou na 
entrevista foi que, apesar de não haver ainda impacto direto de aspectos "verdes" sobre as decisões de embalagem tomadas na AmBev, a questão está longe de ser ignorada. A empresa, aliás, foi uma das pioneiras a implantar ações de reciclagem no Brasil, com o Projeto Brahma para Reciclagem, em 1990.

Existe, na AmBev, um departamento que trata especificamente de assuntos referentes ao meio ambiente, e que responde ao diretor industrial. A coordenadoria de desenvolvimento de embalagem não é a instância corporativa ligada diretamente à questão, mas mantém-se a par de tudo o que pode afetar a sua rotina - inclusive a questão ambiental.

Há que se mencionar que a AmBev tem uma postura de vanguarda no que se refere à preservação do meio natural. De sua criação, em 1999, até hoje, a empresa investiu cerca de US\$ 36 milhões em programas ambientais, e tem hoje oito das suas unidades fabris certificadas com a ISO $14001^{40}$. A empresa é uma das fundadoras do Cempre (Compromisso Empresarial para Reciclagem), instituição formada por empresas privadas para promover e modernizar a reciclagem no Brasil, e desenvolve diversos projetos ligados à proteção ambiental.

Através de um sistema de gestão ambiental, a AmBev conseguiu reduzir em cerca de 9 milhões de metros cúbicos por ano o uso de recursos hídricos, e gerou uma economia anual de cerca de 10000 toneladas de vidro, 600 toneladas de PET e 1800 toneladas de alumínio. A AmBev tem optado também por sistemas limpos de produção, e hoje as fábricas da empresa possuem, segundo informa o seu site institucional na Internet (AmBev, 2003), estações de tratamento de efluentes com capacidade equivalente à de uma cidade de 4 milhões de habitantes.

Outra inovação da empresa na área ambiental é a criação da figura do supervisor de meio ambiente, cuja função é "garantir a operação da indústria dentro dos parâmetros e especificações exigidos pela legislação ambiental vigente e de acordo com as diretrizes corporativas da companhia” (AmBev, 2003). Isso faz parte da política (declarada) da empresa de elevar o nível de informação de seus profissionais sobre importância da preservação ambiental.

\footnotetext{
${ }^{40}$ A AmBev acredita que a melhor maneira de uniformizar os padrões de gestão ambiental de cada uma de suas unidades é a certificação pela ISO 14000.
} 
Não é o meu departamento que cuida [da questão ambiental], mas é óbvio que eu tenho de estar inteirada do que se passa, de todos os projetos de lei, não só sobre embalagem.

Ainda em 1996, a Brahma criou um sistema único de gerenciamento ambiental, hoje ampliado pela AmBev, que integra todas as ações de cada área da companhia. Um grupo multifuncional tem a missão de elaborar um sistema de gestão ambiental aplicável a todas as unidades de negócio que pertencem à AmBev. Foi resultado do trabalho desse grupo a elaboração e a validação da Política Ambiental e das Diretrizes Básicas de Gestão, lançadas em janeiro de 1997, que compõem a base do trabalho de gestão ambiental a ser desenvolvido em cada unidade ${ }^{41}$.

Apesar de todo esse esforço, Camille Kaufmann reconhece que ainda falta bastante para que o consumidor brasileiro passe a dirigir seu comportamento de compra em virtude de apelos ambientais.

\begin{abstract}
A AmBev já tem trabalhos muito importantes ligados à reciclagem de embalagens. No Rio, tem uma recicloteca. A AmBev incentiva essas ações de reciclagem, é parceira de cooperativas que atuam na coleta de lixo. A reciclagem no Brasil vem crescendo. Os índices de reciclagem de alumínio aqui são os mais altos do mundo. Virou uma indústria, mesmo. Consegue gerar empregos e renda para as pessoas. Existe, ainda, pouca divulgação por parte dos órgãos competentes sobre o que a gente deve fazer com as embalagens. A grande parte dos consumidores não é nem instruída. Enquanto não tiver um trabalho de educação... fiquei sabendo agora que a Marta [Suplicy, prefeita de São Paulo] está fazendo coleta seletiva. Tem que educar o povo desde o começo, senão a gente não consegue viabilizar um trabalho de reciclagem no Brasil. A gente separa tudo em casa, e depois vem alguém e mistura tudo de novo.
\end{abstract}

Como fica evidente, apesar de a AmBev ter uma grande preocupação com a questão da responsabilidade ambiental, a dimensão "verde" ainda não tem forte influência sobre as decisões de embalagem da companhia. Há que se notar, contudo, que a empresa está atenta à questão. Entretanto, para que o consumidor passe a exigir produtos mais "verdes”, acredita-se na empresa, seria necessário que se investisse na divulgação de informações e em educação ambiental. Com essa finalidade, a AmBev (à época ainda Brahma) estabeleceu uma parceria com uma ONG chamada Ecomarapendi, do Rio de Janeiro, e montou, em 1993, uma Recicloteca, que a

\footnotetext{
${ }^{41}$ A implementação da Política Ambiental na AmBev varia de uma unidade para outra, em função de diferenças regionais.
} 
empresa afirma ser o principal centro de pesquisas sobre reciclagem e meioambiente no Brasil.

A empresa apóia também projetos de coleta seletiva e reciclagem, como o CSSF - Coleta Seletiva no Bairro São Francisco, parceria entre o Centro Comunitário de São Francisco (CSSF), a associação local dos moradores e a Universidade Federal Fluminense (UFF). Com mais de quinze anos de funcionamento, o CCSF é considerado o primeiro trabalho sistemático de coleta seletiva no Brasil. Outra iniciativa nessa área é o Projeto Viamão, desenvolvido na unidade de Águas Claras do Sul, em Viamão (RS), que troca de latas de alumínio por material de construção. A AmBev fornece apoio, através da Recicloteca, ao Programa Reciclagem Solidária - Cooperativas, que ajuda catadores de materiais recicláveis cooperativados a elevar sua renda, na área metropolitana do Rio de Janeiro.

\begin{abstract}
Acho que a tendência é mesmo a reutilização dos recursos. A tendência é que quanto mais tecnologia, mais fácil a reciclagem dos materiais. É uma questão real, mas são poucos os lugares no mundo que têm reciclagem bottle-to-bottle. E estamos falando de um país que não tem educação para isso. Mas um pouquinho que se faça já é alguma coisa. A AmBev tem responsabilidade social, trabalha nesse sentido, procura informar. A gente distribui cartilhas, dá treinamentos. Foram abertas, no ano passado, cinco cooperativas próximas das fábricas. Então tem um trabalho por trás. A gente tem evoluído. O departamento de meio ambiente tem trabalhos de contabilidade social, análise de ciclo de vida. A gente é filiado ao Cempre. A gente apóia muitos programas.
\end{abstract}

\title{
3.3 - Schincariol
}

Fundada em 1939 por Primo Schincariol para fabricar refrigerantes, a Schincariol, localizada na cidade de Itu, no interior de São Paulo, lançou a sua primeira cerveja apenas 50 anos depois, em 1989. Atualmente, a Schincariol possui seis fábricas ${ }^{42}$, que juntas têm capacidade para produzir cerca de 2,1 bilhões de litros de cerveja por ano.

\footnotetext{
${ }^{42}$ Além da sede da empresa, em Itu (SP), há unidades em Alagoinhas (BA), Cachoeiras de Macacu (RJ), Caxias (MA), Alexânia (GO) e Recife (PE).
} 
Em pouco mais de uma década, a empresa já contava com três marcas de cerveja: a Nova Schin ${ }^{43}$ (Pilsen, Munique e Sem Álcool), a Glacial e a Primus, marcas que em conjunto, de acordo com os dados Nielsen de setembro de 2003, davam ao Grupo Schincariol 11,5\% do mercado brasileiro de cerveja.

Para o presente trabalho foi entrevistado o gerente de marketing corporativo da empresa, o senhor Luiz Cláudio Taya de Araújo. O departamento comandado por esse executivo é responsável pelas decisões de embalagem da Schincariol, trabalho que é desenvolvido em conjunto com o departamento técnico da empresa. Cabe à área técnica verificar a viabilidade das idéias trazidas pelo marketing, em função de linhas de enchimento e demais equipamentos existentes.

A estratégia da empresa ao manter três marcas distintas é trabalhar com posicionamentos que cubram diferentes públicos-alvo. A cerveja Primus busca atingir o segmento premium. A Glacial é posicionada como produto de baixo preço, tomando o lugar antes ocupado pela marca Schincariol. A Nova Schin, que substituiu a marca Schincariol, está sendo reposicionada para o segmento de preço médio.

Para as três marcas, contudo, os tipos de embalagem utilizados são os mesmos. A garrafa de vidro retornável com capacidade para 600ml é dirigida principalmente a pontos-de-dose como bares e restaurantes (em geral, nos menos sofisticados), e responde por cerca de $70 \%$ do mix de embalagens da Schincariol. O preço final do produto ao consumidor é um aspecto importante desse vasilhame, uma vez que não é preciso que se compre a embalagem (como acontece quando são adquiridas latas ou garrafas descartáveis), ficando o dinheiro do consumidor destinado à compra do produto em si. Como a embalagem retorna cerca de 30 vezes, o custo da embalagem para a cervejaria fica diluído, o que possibilita às cervejarias vender o produto a um preço (por litro) mais baixo a ainda auferir margens maiores. Com menor preço por litro, também estimulam-se as vendas.

Ao contrário do que defende o Sindicerv, entretanto, a Schincariol não vê lugar para a volta da garrafa de $600 \mathrm{ml}$ aos supermercados e postos de auto-serviço, porque o espaço nas lojas é limitado, e a logística é extremamente complicada. Isso, segundo

\footnotetext{
${ }^{43}$ No final de agosto de 2003, a empresa mudou o nome de seu principal produto, a cerveja tipo pilsen que tinha o nome da empresa e passou a se chamar Nova Schin
} 
Araújo, porque “o estoque dos supermercados são as próprias prateleiras”. Na Schincariol acredita-se ser muito difícil a reversão da tendência imposta pelos varejistas de substituir as garrafas retornáveis por alternativas descartáveis nesse tipo de ponto-de-venda.

O segundo tipo de embalagem mais usado pela Schincariol é a lata de alumínio, destinada principalmente ao consumo nos lares, e que responde por cerca de $25 \%$ do mix de embalagens de cerveja da Schincariol. O principal motivo para que as latas sejam dirigidas ao consumo em casa é o seu formato.

Eu compito por um pouco do escasso espaço das geladeiras. Eu luto por um espaço na porta da geladeira contra o requeijão, a maionese... Para essas circunstâncias, as latas são mais apropriadas que as garrafas, que ocupam mais espaço.

A garrafa de vidro descartável long neck completa, com aproximadamente 5\% de participação, o composto de embalagens da empresa. Voltada aos pontos-de-dose onde o consumidor quer status, tais como restaurantes e bares da moda, a garrafa long neck tem a característica de transmitir valores de marca, um lado aspiracional que a lata não é capaz de agregar.

O consumidor que quer impressionar numa danceteria ou num bar prefere a garrafa long neck à lata. A garrafa tem essa capacidade de comunicar mais fortemente os valores de marca que nós temos trabalhado.

A Schincariol mostra-se resistente a adotar novos tipos de embalagens. Para a empresa, as garrafas plásticas, sejam elas de PEN ou de PET, ainda não se consolidaram como alternativa viável. Mesmo com diversas opções sendo oferecidas no mercado, na cervejaria de Itu acredita-se que nenhuma obedece a todos os aspectos técnicos e mercadológicos necessários. Por isso, a empresa não considera, no curto prazo, a adoção de garrafas plásticas.

Quanto às latas de aço, dois fatores mostraram-se por trás da não adoção desse tipo de embalagem pela Schincariol: aparência ("a lata de aço tem menos brilho que a de alumínio”) e reciclabilidade. Este segundo ponto foi enfatizado por Araújo. “Tem a questão da reciclagem do alumínio, que é fantástica. O Brasil é o maior 
reciclador de latas de alumínio do mundo. O aço tem um problema maior nesse sentido.”

Sobre rumores existentes no mercado de que estariam sendo desenvolvidas garrafas de vidro de 200ml (stubbies), que teriam benefícios tributários, o executivo de marketing afirma que a Schincariol não tem projetos para adotar tal solução de embalagem. “A gente não está trabalhando com isso. Sei que tem gente fazendo, mas nós não.”

Na Schincariol, os fatores mais importantes na escolha de embalagens são, portanto, custo, imagem, adequação a cada canal, aspectos técnicos (tais como as linhas de enchimento existentes) e preferências do consumidor. A importância relativa de cada fator nas escolhas de embalagem não é fixa, pois depende do produto que se vai lançar - se for um produto que permita preço prêmio, pode-se “jogar” mais com os outros fatores; caso contrário, o custo é sempre um fator restritivo. Nas palavras do executivo, “as cervejarias estão cada vez mais pressionadas para reduzir custos”, porque “cerveja é uma commodity.” O aspecto ambiental ainda mostra-se incipiente, mas não é ignorado. Especialmente no que se refere a possíveis exigências do poder público.

Na estratégia de posicionamento das marcas da Schincariol, a embalagem é um elemento muito importante, mas não o principal, e serve como apoio na criação dos valores de marca. Araújo declara, nesse sentido, que "primeiro eu tenho que saber o que eu quero ser, para depois escolher a forma de chegar lá. A embalagem entra nesse segundo momento." Para saber, portanto, como o marketing "verde” tem influenciado as decisões da empresa sobre embalagem, torna-se importante analisar quais são os valores de marca que a embalagem ajuda a reforçar.

Para falar do perfil do consumidor e dos atributos de marca de cerveja da Schincariol, foi solicitado ao entrevistado que se ativesse especificamente à Nova Schin, o principal produto da empresa. O que se obteve na entrevista foi que, no reposicionamento da marca dessa cerveja em particular, a Schincariol está trabalhando com conceitos aspiracionais, dirigindo a Nova Schin para um público que a empresa classifica como sendo jovem, seguro, arrojado, ousado, realizador, que exerce liderança em seu grupo de referência e que está se estabelecendo (em 
termos emocionais, financeiros e profissionais). A marca Schincariol não tinha esses valores, de acordo com Araújo, e acabava competindo apenas por preço.

A cerveja Schincariol era um produto industrial, que foi lançado e trabalhado dessa forma. A indústria fazia e vendia. Faltava o aspecto emocional, experiencial da marca. Isso foi um dos fatores que motivaram o lançamento da Nova Schin.

Não foi mencionada por Araújo, em nenhum momento, a preocupação do consumidor com o meio ambiente como uma atitude importante para o posicionamento da marca, nem como elemento decisivo para o consumidor na escolha por um determinado tipo de embalagem. Segundo o entrevistado, o que os consumidores têm em mente no momento da escolha é a busca por praticidade, a conquista de espaço e a liderança frente ao seu grupo de referência, dependendo do local e do contexto do consumo.

Quando questionado sobre a consideração, na Schincariol, de novas tendências de consumo que pudessem alterar essa situação, Araújo mencionou a maior presença de mulheres entre os consumidores de cerveja. Para o executivo de marketing, a mulher, que antes era mal-vista se chegasse a um bar e pedisse uma cerveja, tem conseguido conquistar cada vez mais seu espaço.

O consumidor “verde”, por outro lado, ainda não é uma realidade no Brasil ao menos na análise da Schincariol. Esse segmento só vai crescer com a maior educação das pessoas, conforme se acredita na empresa. Por mais que a legislação caminhe rápido no sentido de responsabilizar a indústria - como já vem acontecendo -, os consumidores só exigirão produtos ambientalmente melhores quando tiverem um grau maior de informação.

A proteção do meio ambiente é muito importante, vai estourar a qualquer momento. Eu acho que em menos de um ano vai ser muito forte. Mas não acredito que o consumidor brasileiro esteja muito ligado a isso, porque ele não tem muita informação. Isso só poderia mudar com mais educação.

Porém, a empresa não tem ignorado os sinais emitidos pelo Poder Público de que a preocupação com o meio ambiente possa vir a se tornar cada vez mais importante nas suas tomadas de decisão. Para responder à crescente 
responsabilização pelo descarte das embalagens usadas, por exemplo, a empresa já vem apoiando entidades e programas voltados à preservação ambiental. Hoje, a Schincariol ainda não trabalha com sistemas de contabilidade ambiental, mas, de acordo com Araújo, está caminhando nessa direção.

Da entrevista, pode-se perceber que a Schincariol ainda não considera o comportamento "verde" do consumidor como uma realidade capaz de afetar, no momento, suas decisões sobre embalagens de forma decisiva. Evidentemente, isso não significa que a empresa ignore essa possibilidade. Aparentemente, entretanto, a cervejaria ituana está mais preocupada em responder a exigências legais do que em se engajar mais ativamente em atividades que possam conduzi-la a padrões mais sustentáveis de desenvolvimento. Isso fica claro com constatação de que inexiste, na empresa, um sistema de contabilidade ambiental capaz de apontar possíveis ineficiências decorrentes da geração de resíduos que poderiam ser evitados com o redesenho de processos produtivos pautados pela eco-eficiência e resultantes de análises de ciclo de vida. Também é sinal dessa postura o fato de que, quando precisa responder a demandas ambientais, a empresa tenha optado por apoiar atividades de terceiros, e não por desenvolver internamente tais atividades.

Não se pode, contudo, inferir que a empresa não tem preocupações ambientais. Aliás, torna-se claro que essa não é a realidade quando se observam as iniciativas ambientais apoiadas pela empresa, como a preservação de áreas de mata atlânctica na Serra de Macacu (RJ), o trabalho de prevenção contra erosão em Alexânia (GO) e a substituição do óleo combustível por gás natural em Itu (SP) (Schincariol, 2003) Apenas constata-se que a Schincariol ainda não está reorientando suas atividades pela ótica do marketing “verde”, o que não é nenhum crime ambiental.

Ao não considerar o consumerismo "verde” como uma ameaça iminente, tornase, em certa medida, natural que a Schincariol não esteja incluindo a dimensão “verde” em seus esforços de marketing. A empresa está priorizando em seu posicionamento de marca aspectos aspiracionais e experienciais que não possuem relação com a questão ambiental. Dessa forma, está buscando conquistar o consumidor por apelos outros que não os ligados à preservação do meio ambiente. 
Mais uma vez, entretanto, é importante que se ressalte que isso não equivale a afirmar que a Schincariol reforça valores "nocivos ao ambiente”. Serve apenas para reiterar o que foi constatado anteriormente, mostrando que o marketing "verde" ainda não se constitui num fator condicionante das decisões sobre embalagens da empresa. Dessa forma, a empresa não possui indicadores ambientais capazes de atrair consumidores "verdes", nem atividades que permitam fazê-la reduzir custos através de uma gestão ambiental baseada em estudos de ACV e no ecodesign.

\section{4 - Análise}

Depois de apresentados os resultados das entrevistas, torna-se necessário analisá-los à luz do que foi discutido nos capítulos anteriores. A primeira conclusão a que se pode chegar é que, apesar dos indícios que sugerem a importância da dimensão "verde” no comportamento do consumidor, há hoje, entre as cervejarias que operam no Brasil, pouco impacto desse fator nos processos de decisão sobre embalagens. Nessas empresas, acredita-se que o consumidor brasileiro ainda é pouco informado sobre a importância de seu comportamento para a preservação do meio ambiente, e que, por esse motivo, apelos “verdes” não têm repercussão nos processos de compra.

Aspectos técnicos preponderam nas decisões sobre embalagem das três cervejarias, sendo o custo um fator limitante, dado o baixo valor agregado do produto. Se, por um lado, mudanças nas embalagens para as cervejas de linha da AmBev estão limitadas pelo impacto que podem ter sobre o custo final do produto, a exemplo do que ocorre na Kaiser e na Schincariol, por outro lado há nessa empresa um maior espaço para projetos especiais de reforço de imagem de marca, que resultam em embalagens com maior valor agregado. Exemplos recentes, como o lançamento da Skol Beats e as edições especiais da Bohemia, mostram que a embalagem tem uma grande importância nas estratégias de posicionamento de marca da AmBev. 
Constatou-se, também, que cada tipo de embalagem utilizada hoje pelas cervejarias mostra-se mais apropriado em diferentes situações de consumo. Garrafas retornáveis de $600 \mathrm{ml}$ são vistas como a melhor embalagem para que as cervejarias recuperem suas espremidas margens, e por isso a maior presença desses vasilhames é defendida - oficialmente, através do Sindicerv - pelas empresas. O retorno desse tipo de embalagem aos supermercados ${ }^{44}$, contudo, encontra resistência dos varejistas, que não querem arcar com o ônus de estocar as garrafas vazias. Para as cervejarias, além de viabilizar maiores margens, a garrafa retornável representa uma barreira a novos entrantes, em função da complexidade da logística reversa necessária para viabilizar esse sistema de embalagem, e dos altos investimentos requeridos para que se crie um acervo de vasilhames. A garrafa retornável de $600 \mathrm{ml}$, hoje, é vista pelas cervejarias como a embalagem ideal para os chamados pontos-de-dose em que o consumidor bebe em grupo, na mesa ou no balcão, os locais onde se dá a maior parte do consumo de cervejas no Brasil.

Nas situações em que o consumidor está mais preocupado com a imagem perante de seu grupo de referência, por sua vez, a embalagem que se mostra mais indicada é a garrafa de vidro long neck. De acordo com o que se obteve nas entrevistas, é esse tipo de embalagem que possui as melhores características para agregar valor ao produto, gerando ganhos de imagem para a marca, e possibilitando margens um pouco maiores para as cervejarias. É, por isso mesmo, uma embalagem apropriada para o mercado frio, especialmente os locais mais sofisticados e voltados para o público mais jovem.

Apesar de também ser apropriada para os canais frios, a lata mostrou ter maior força no varejo, onde chega ao consumidor final com preço mais baixo que as garrafas long neck. Preferida por alguns consumidores por ocupar pouco espaço na geladeira, é o tipo de embalagem que gera as menores margens para as cervejarias. Uma alternativa para melhorar isso surgiu com a lata de aço, que é mais barata que a de alumínio (detentor da quase totalidade do mercado de embalagens metálicas para

\footnotetext{
${ }^{44}$ Por pressão das redes de varejo, as lojas de supermercado - especialmente as dos grandes centros urbanos - praticamente não oferecem esse tipo de embalagem aos consumidores. Isso porque os supermercadistas não estão dispostos a ocupar espaço para armazenar garrafas vazias.
} 
cerveja), mas problemas de imagem podem dificultar a penetração desse material no mercado. A lata de alumínio goza, entre os profissionais que decidem sobre embalagens nas cervejarias, de uma imagem extremamente positiva em termos de sua reciclabilidade - foi o único material citado por todos os entrevistados como sendo “altamente reciclável”. Foi reconhecido, entretanto, o esforço da indústria do aço para minimizar essa vantagem.

As embalagens plásticas, ao menos aparentemente, encontram certa resistência por parte da indústria cervejeira. Os problemas não são mais técnicos, mas puramente mercadológicos. Todas as cervejarias admitiram já ter analisado alternativas de acondicionamento em garrafas plásticas, mas nenhuma parece disposta a ser a primeira a lançar, em seus produtos de linha, tal sistema de embalagem. Dados os investimentos necessários para a conversão das linhas para trabalharem com PET, contudo, AmBev e Schincariol estão em situação mais favorável do que a Kaiser para adotar o plástico em suas embalagens, por já possuírem linhas de refrigerante preparadas para esse material.

A embalagem, portanto, mostrou-se uma ferramenta útil nas estratégias de posicionamento das cervejarias, que pode ser explorada com mais intensidade quando se trabalha com um portfólio de marcas. Por esse motivo, foi na AmBev que a importância da embalagem nas estratégias de posicionamento apareceu mais explicitamente, e na Schincariol onde ela se mostrou com mais timidez. No posicionamento das marcas administradas pelas empresas entrevistadas, contudo, não aparece a preocupação com o ambiente. Os valores mais trabalhados são status, prestígio, sucesso, bem estar, conveniência e preço.

O possível aumento no rigor da legislação ambiental e a crescente importância da responsabilidade ambiental para a imagem corporativa, por sua vez, têm sido objeto de estudo nessas cervejarias. O grau com que isso ocorre, entretanto, varia de empresa para empresa. Kaiser e AmBev mostram-se bastante comprometidas com o assunto, e já possuem departamentos que tratam exclusivamente de aspectos ligados ao meio ambiente, com vistas a viabilizar a implementação de políticas de gestão ambiental. De maneira mais incipiente, a Schincariol tem optado por responder às 
demandas ecológicas - oriundas do poder público ou advindas da sociedade apoiando ações externas à companhia.

Dessa forma, enquanto Kaiser e AmBev caminham na direção de políticas ambientais sustentáveis, baseadas em estudos de contabilidade ambiental, análises de ciclo de vida e empenho na prevenção da poluição, a Schincariol ainda atém-se a ações mais reativas. Considerando-se a crescente intensidade do debate sobre resíduos sólidos e preservação do meio natural, conforme mostrado nos capítulos 1 e 2 deste trabalho, Kaiser e AmBev apresentam-se mais bem estruturadas do que a Schincariol para responder às demandas ambientais. Pode-se dizer que esta última encontra-se num estágio anterior de preocupação, o que não significa que a empresa não possui responsabilidade ambiental. Apenas indica que a Schincariol teria maior dificuldade para orientar suas atividades pela perspectiva do marketing “verde”.

Relevante para os objetivos desta dissertação é o fato de que tanto AmBev quanto Kaiser enxergam nas políticas de gestão ambiental não apenas um meio de melhorar sua imagem perante os diferentes stakeholders, mas vêem nelas uma maneira de eliminar desperdícios e de reduzir custos operacionais.

Cabe, finalmente, observar que as embalagens, dada a grande importância que possuem nas estratégias de posicionamento de marca, tornam-se, ao menos potencialmente, poderosos instrumentos para comunicar aos consumidores os valores “verdes” adotados por essas empresas, quando necessário. Isso significa que cada material de embalagem encontra diferentes oportunidades nesse mercado.

A lata de alumínio, por exemplo, por causa dos altos índices de reciclagem do material no Brasil, desfruta de uma imagem ambiental muito positiva. A garrafa retornável de vidro é outra embalagem que teria facilidade para transmitir valores ecológicos, ficando as garrafas de vidro long neck e as latas de aço numa posição intermediária, mas ainda favorável, uma vez que a reciclagem do vidro e do aço já ocorre em todo o território nacional. As garrafas plásticas, sejam elas de PET ou de PEN, são as embalagens que, teoricamente, teriam maior dificuldade em comunicar valores de responsabilidade ambiental aos consumidores - o baixo valor residual da sucata dificilmente viabilizaria programas de reciclagem nos níveis dos observados com o alumínio, por exemplo. 


\section{Capítulo 4 - Conclusão}

Até agora, esta dissertação tentou mostrar que fatores que são exógenos à empresa, como o comportamento do consumidor e a legislação ambiental, podem criar um contexto favorável ao marketing "verde”. Ao discutir temas como desenvolvimento sustentável, contabilidade ambiental, análise de ciclo de vida e logística reversa, este trabalho procurou apresentar argumentos para justificar a afirmação de que o marketing "verde”, por sua vez, pode representar mais oportunidades do que ameaças para as empresas.

Em seguida, foram apresentados estudos de caso para averiguar até que ponto essa nova realidade está afetando as cervejarias que operam no Brasil. Para tanto, optou-se por trabalhar especificamente com as decisões dessas empresas a respeito das embalagens que utilizam. Isso porque, como explicado no Capítulo 1, as embalagens são a interface entre o consumidor e a questão ambiental, pela óbvia relação entre o descarte de embalagens e a geração de resíduos sólidos. Por constituírem a parcela visível do lixo urbano, as embalagens têm sido alvo de crítica de grupos ambientalistas e de legislação específica.

Baseando-se em modelos de comportamento do consumidor que usam uma abordagem cognitiva, então, esta dissertação sugeriu que a maior presença dos temas ligados à preservação ambiental e à questão do lixo urbano no cotidiano dos consumidores aumentaria o volume disponível (e acessível) de informações sobre o assunto, levando-os a desenvolver uma preferência por produtos “verdes”.

Neste capítulo, o que se procura fazer é identificar algumas das implicações da análise feita nos capítulos anteriores para a teoria de marketing e para os profissionais que trabalham no dia a dia das empresas com as decisões sobre embalagens. Não é o objetivo deste trabalho ser prescritivo. Ao contrário, o que se quer aqui é mostrar que a decisão de tornar-se “verde” não é simples.

A contemplação dos elementos que estão compelindo as empresas para um comportamento socialmente mais responsável sugere que a dimensão “verde” dos negócios deve ser examinada em sua totalidade. Pressões sociais e legais tornam 
cada vez mais improvável o sucesso de empresas que não observarem um nível mínimo de responsabilidade ambiental.

Ficou claro na análise que se fez nesta dissertação, contudo, que ainda se temem potenciais trade-offs entre ações orientadas economicamente e aquelas conduzidas visando à preservação ambiental. Como demonstra a literatura utilizada nos capítulos anteriores, entretanto, ao partir desse pressuposto as empresas podem estar deixando escapar boas oportunidades de negócios.

Em primeiro lugar porque, como indicam os trabalhos de autores como Porter e Van der Linde (1995) e estudos elaborados por diferentes organismos internacionais (DEFRA, 2001b; ONU, 2001), o desperdício, em qualquer forma, reflete ineficiências no sistema produtivo. Ao passarem a incluir a dimensão ecológica em suas considerações, as empresas poderiam identificar as fontes dessas ineficiências e, eliminando-as, reduzir custos.

Em segundo lugar, as empresas que não investem no desenvolvimento sustentável porque análises de investimento conduzidas unicamente em termos econômicos indicam não ser esta a melhor alternativa podem estar deixando de apreciar as exigências de um segmento cada vez maior de consumidores sensíveis a apelos ambientais.

Finalmente, essas empresas deveriam estar levando em consideração o número cada vez maior de estudos que recomendam que custos ambientais gerados nos processos produtivos e não internalizados nos preços dos produtos (e portanto divididos com a sociedade) passem a ser contabilizados pelas empresas. Se essa tendência se confirmar, as corporações que mantiverem políticas de gestão ambiental fundamentadas em estudos de ciclo de vida e que trabalhem na busca constante pela eco-eficiência, com sistemas de logística reversa, estarão um passo adiante, por já terem acumulado experiência no cálculo e na redução desses custos. 


\section{1 - Implicações para a Teoria de Marketing}

Portanto, às empresas não basta adotar estratégias “verdes” que sejam limitadas a algumas de suas atividades, como o desenvolvimento de produtos e a comunicação. É necessário, para que se busque o desenvolvimento sustentável (e para que se atendam as expectativas dos consumidores “verdes”), um trabalho de reorientação de todas as atividades da empresa. Para tal, necessita-se recorrer a ferramentas como a contabilidade ambiental e a análise de ciclo de vida, de forma que se avaliem os verdadeiros impactos da atividade produtiva sobre o meio natural.

Dessa maneira, como resultado da maior intensidade dos debates acerca do desenvolvimento sustentável e da preservação do meio ambiente, o que se vê é o crescimento no número de vozes que sugerem que a dimensão "verde" passe a integrar todas as instâncias das corporações. Isso implica na necessidade de se fazer uma releitura, a partir da perspectiva "verde", das teorias de administração em geral, e da teoria de marketing em particular, como sugerido por Peattie (1999, 2001). Isso permitiria que se superassem paradigmas que hoje mostram-se insuficientes para auxiliar as empresas na busca pelo desenvolvimento sustentável. A consolidação de metodologias que permitam traduzir em valores os custos ambientais, incorporandoos às estruturas de custo das empresas, ou, em outras palavras, “internalizar as externalidades”, é vital nesse processo.

As dificuldades, evidentemente, são muitas. Se, por um lado, as discussões ainda são incipientes, e a complexidade do tema é imensa, por outro lado há que se lidar com diversos grupos de interesse, que muitas vezes têm objetivos concorrentes. Contudo, incursões no campo da contabilidade ambiental, mostradas neste trabalho, sugerem que rever a teoria existente é não apenas necessário, mas também viável.

\section{2 - Implicações para as empresas}

Esta dissertação indicou que a consciência ambiental dos consumidores pode afetar as suas preferências no momento da compra, e que a adoção de estratégias de 
posicionamento "verde" deve ser precedida por mudanças organizacionais mais profundas. Daí se segue que as empresas precisarão decidir se atenderão as expectativas mínimas dos consumidores em relação à preservação ambiental, ou se enfatizarão a dimensão ecológica em toda a sua estratégia (McIntosh et al., 1998).

Em outras palavras, pode-se dizer que um posicionamento "verde” (para ter credibilidade) requer a adoção de uma estratégia de marketing sustentável (conforme definição de Peattie, 1999; 2001). Algumas empresas podem achar menos complicado adotar tal posicionamento porque já possuem processos de produção “mais limpos” do que os de seus concorrentes, ou porque as marcas de que são donas estão posicionadas próximas de valores de responsabilidade social e ambiental. Nos casos analisados, ficou claro, por exemplo, que a Schincariol teria mais dificuldades em perseguir o desenvolvimento sustentável do que a Kaiser e a AmBev, que já mantêm departamentos exclusivamente dedicados à questão, e que já se empenham em implementar políticas de gestão ambiental em todas as suas unidades.

Por outro lado, evidenciou-se, com a revisão da literatura que se fez no Capítulo 2, que o domínio de ferramentas que auxiliem a empresa a caminhar na direção da sustentabilidade, como a ACV e a logística reversa, podem significar uma fonte de vantagem competitiva. Como se mostrou, ao compreender os impactos totais de seu processo produtivo sobre o ambiente, as empresas podem melhorá-lo nos pontos em que há a geração de resíduos (ou “output não-produto”), reduzindo custos. A política de gestão ambiental da AmBev, por exemplo, tem trazido resultados positivos em termos econômicos para a companhia, como a própria empresa registra em seu site corporativo. Além de alcançar o objetivo inicial (unificação de todas as ações ambientais), o
processo de certificação levou a Companhia a reduções de custos expressivas através
dos programas para evitar o desperdício, aproveitar resíduos, conservar energia e
economizar água. (AmBev, 2003).

Somam-se aos benefícios tangíveis uma série de outros menos palpáveis, como o aumento do moral dos colaboradores e ganhos de imagem.

Se se considerar que, ao que indica a literatura sobre o tema, cedo ou tarde os custos ambientais serão imputados às empresas, seguindo o princípio do poluidor- 
pagador, àqueles que começarem a lidar com a questão com maior antecedência caberá a vantagem da experiência acumulada.

Mais que isso, como mostram os trabalhos de comportamento do consumidor que partem da perspectiva cognitiva, o aumento no volume de informações acerca da questão dos resíduos sólidos e da degradação ambiental provavelmente criará uma maior massa de consumidores "verdes”. Dessa forma, surge como uma conseqüência natural a idéia de que a oferta de produtos e serviços ambientalmente "mais amigáveis” poderia atrair esse grupo de compradores potenciais, alavancando as vendas. Peattie (2001), entretanto, recorre ao argumento (coerente com o princípio econômico de maximização da utilidade) de que qualquer pessoa preferiria um produto "mais verde” se nenhum sacrifício (como preço superior) fosse exigido em troca, o que indica que as oportunidades do marketing “verde” podem ser maiores do que se imagina a princípio.

Em função disso, Peattie (1999, 2001) sugere que, para que a dimensão “verde” seja atraente para o consumidor, o foco deve ser alterado do comprador para a compra. Esse autor propôs uma matriz (Figura 4.1) que leva em conta a confiança percebida pelo consumidor de que suas ações terão efeitos positivos sobre o meio natural, e os sacrifícios envolvidos no processo de compra, como a busca por lojas específicas ou o pagamento de um preço-prêmio. 


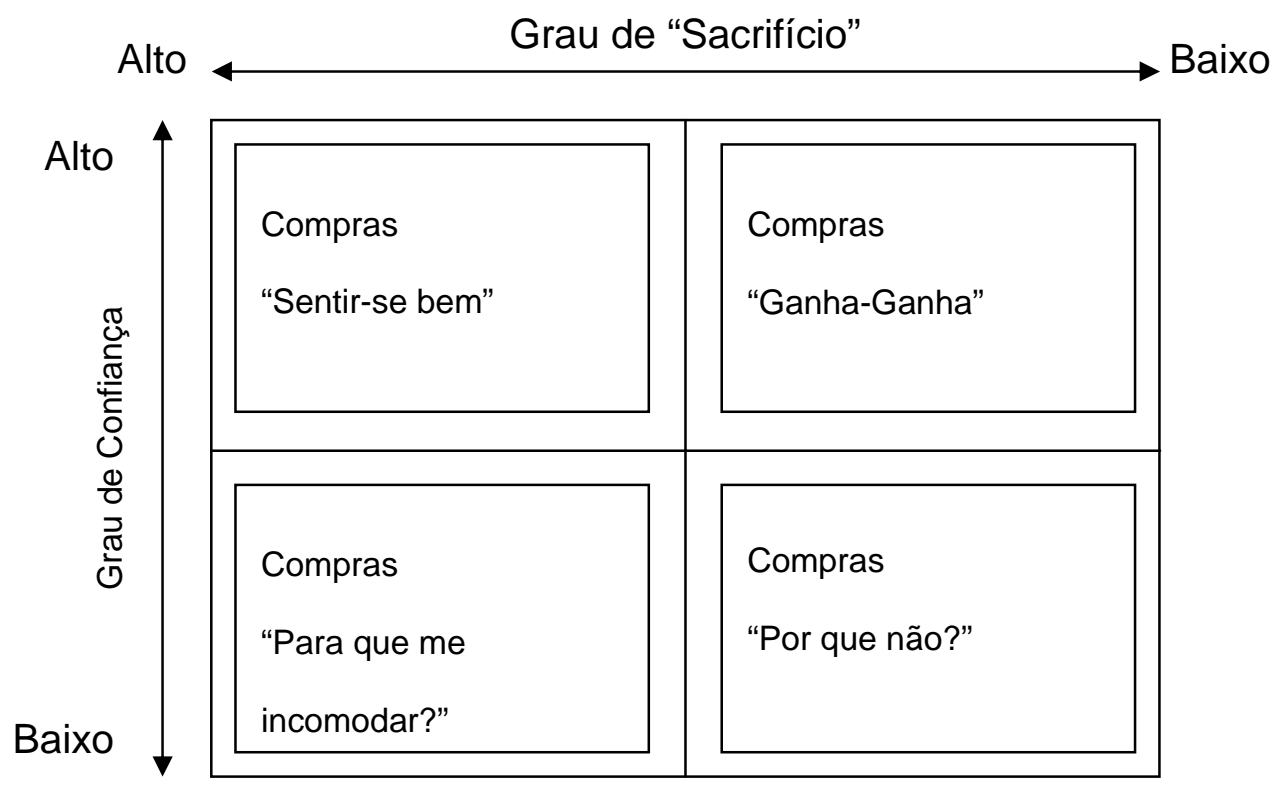

Fig. 4.1 - Matriz de percepção de compras "verdes" (Fonte: Peattie, 1999, 2001)

Pelo raciocínio de Peattie, impor sacrifícios aos consumidores significa restringir as vendas de produtos "verdes” a situações que se encontram na célula “Compras ‘Sentir-se Bem'”, que são aquelas em que os consumidores aceitam pagar um preço extra (seja em termos monetários, seja despendendo mais tempo para realizar suas compras, seja deslocando-se para lojas onde produtos "verdes" estejam disponíveis) para realizar uma compra "ambientalmente correta”, por confiarem que não se trata de uma oferta "verde” oportunista. Ao orientarem os negócios sob a ótica do marketing "verde”, entretanto, as empresas - segundo o raciocínio de Peattie - passariam a tornar seus produtos atraentes nas demais situações de compra, representadas pelas outras três células da matriz.

A discussão da literatura mostrou, por sua vez, que ações orientadas ecologicamente não são incompatíveis com a eficiência econômica. Pelo contrário, mostrou que é possível que se obtenham reduções de custo através de medidas que coloquem as empresas na rota do desenvolvimento sustentável. Sendo assim, a presente pesquisa indica que os benefícios de se repensarem os negócios sob a perspectiva da sustentabilidade podem transcender em muito os aspectos altruístas. 
Como revelam as discussões sobre desenvolvimento sustentável, contabilidade ambiental, análise de ciclo de vida e logística reversa contidas neste trabalho, a gestão ambiental orientada pela lógica da sustentabilidade pode resultar em benefícios tangíveis (como, por exemplo, a redução do desperdício decorrente da revisão de processos) e intangíveis (como uma eventual melhora na imagem da empresa).

Políticas de gestão ambiental, portanto, podem ser capazes de melhorar as margens das empresas não através da cobrança de preços prêmio (um sacrifício que se impõe ao consumidor), como tem sido a tendência dos produtos "verdes” lançados até hoje, mas através da redução de custos. Com isso, ações de marketing "verde” não estariam limitadas à célula "Compras 'Sentir-se Bem'” da Figura 4.1, e seriam deslocadas para a célula “Compras 'Ganha-Ganha'”, permitindo a inclusão de um grupo maior de consumidores (não haveria motivos, ainda, para que os apelos não atraíssem os consumidores nas compras localizadas nas outras três células). Essa seria a situação mais desejável em termos de oferta "verde”, por não exigir sacrifícios dos consumidores, oferecendo-lhes em troca produtos ambientalmente confiáveis. Isso se mostra muito apropriado para o mercado estudado, em que se trabalha com um produto de massa com baixo valor agregado, que não permite grandes acréscimos no preço, a não ser em ações de nicho.

No caso específico das cervejarias, ainda, há que se ter em mente que as embalagens continuarão sendo um elemento crucial nas estratégias de posicionamento de marca (Walczyk, 2001). Como as garrafas de vidro e as latas têm bons apelos ambientais, é provável que essas empresas não tenham dificuldades para enfatizar os atributos ecológicos de suas embalagens. Por outro lado, a adoção de garrafas plásticas precisa ser avaliada com cautela, com ações de pós-consumo sendo obrigatoriamente levadas em conta. 


\section{3 - Considerações finais}

O crescente debate sobre a preservação do meio ambiente, particularmente no que se refere ao papel da embalagem na questão do lixo urbano, faz com que as empresas fabricantes de bens de consumo - as grandes usuárias de embalagens mantenham-se atentas à forma com que os consumidores reagem a apelos ambientais.

Estruturar-se para responder às demandas ambientais impostas pela legislação, por pressões de grupos ambientalistas ou por preferências do consumidor, entretanto, mostra-se como uma alternativa economicamente viável, até desejável. Não se trata apenas de discutir se a busca pela sustentabilidade dos negócios pode ser favorável para a imagem das empresas. O que esta dissertação mostrou é que restringir os esforços “verdes” das empresas à comunicação e ao desenvolvimento de novos produtos não é suficiente para atrair o consumidor "verde", e pode ter efeitos negativos se a empresa não tiver uma postura coerente em todas as suas atividades.

Além disso, este trabalho procurou indicar, apresentando o debate atual sobre desenvolvimento sustentável e temas correlatos, que a gestão ambiental pode ser uma aliada importante das empresas na hora de reduzir custos de produção. É bem verdade que muitos desses custos ainda são divididos com a sociedade, mas, como a literatura recente sobre o assunto sugere, não está longe o dia em que isso pode mudar.

\section{4 - Limitações}

Se, por um lado, a opção por colocar o foco numa indústria específica, a de cervejas, tem a vantagem de permitir que se investiguem a fundo as principais empresas do setor, de forma a levantar como a situação analisada as afeta, isso traz também desvantagens. O reverso da moeda é que as conclusões a que se chegar serão válidas somente para aquele universo. Ou, como colocado por Maxwell (1996), quando se adota esse tipo de procedimento, não há generalização externa. 
Além disso, dado que o volume de literatura produzida no Brasil sobre as questões aqui estudadas, como marketing "verde" e comportamento "verde" do consumidor, ainda é escasso, o autor viu-se obrigado a recorrer a escritos estrangeiros (invariavelmente produzidos em países economicamente mais desenvolvidos). É preciso que se reconheça, por isso, que algumas peculiaridades do consumidor brasileiro podem não estar sendo consideradas na análise.

\section{5 - Recomendações para Estudos Futuros}

Como o presente trabalho restringiu-se a uma indústria específica, com poucas empresas dominando a quase totalidade do mercado e com produtos de baixo valor agregado, seria importante que novos estudos fossem conduzidos em outras indústrias com características diferentes. Além disso, seria recomendável que, no futuro, fossem conduzidas pesquisas quantitativas com consumidores brasileiros, a fim de verificar a sensibilidade deles com relação a temas relacionados com o meio ambiente. Isso permitiria às empresas que pretendem direcionar suas atividades seguindo os princípios do desenvolvimento sustentável o dimensionamento do mercado para quem podem dirigir seus apelos ecológicos. 


\section{BIBLIOGRAFIA}

AAKER, David (1996). Building Strong Brands. London: Free Press.

ABIVIDRO (2003). Reciclar conceitos: um compromisso com o futuro. Disponível em http://www.abividro.org.br/duvidas.asp

AMBEV (2003). Site corporativo, http://www.ambev.com.br

BAILEY, Ian (1999). Flexibility, Harmonization and the Single Market in EU Environmental Policy: The Packaging Waste Directive. Journal of Common Market Studies, 37 (4), pp. 549-571.

BARDE, Jean-Philippe \& David W. Pearce (editores) (1995). Valuing the Environment. London: Earthscan Publications Ltd.

BARNEY, Jay (2001). Is the Resource-Based "View" a Useful Perspective for Strategic Management Research? Yes. Academy of Management Review, 26 (1), pp. 41-56.

BB\&PA - British Beer and Pub Association (2001) Statistical Handbook: A Compilation of Drinks Industry Statistics. London: Brewing Publications Ltd.

BEI, Lien-Ti \& Eithel M. Simpson (1995). The Determinants of Consumers' Purchase Decisions for Recycled Products: An Application of AcquisitionTransaction Utility Theory. Advances in Consumer Research, 22, pp. 257-261.

BELK, Russell W. (1995 [1975]). Situational Variables and Consumer Behavior. In Enis, Ben M., Keith K. Cox, \& Michael Mokwa (eds.) Marketing Classics: A Selection of Influential Articles. New Jersey: Prentice Hall, pp. 168-178.

BIFFA (2001). Waste: A Game of Snake and Ladders? Brewing and Distilling. Disponível http://www.biffa.co.uk/publications/snakes/brewing.html 
BRADY, John \& Ian Davis (1993). Marketing's Mid-Life Crisis. McKinsey Quarterly. 2, pp. 17-28.

BRASIL, MINISTÉRIO DA JUSTIÇA (2000). CADE aprova criação da AmBev. Disponível http://www.mj.gov.br/acs/releases/2000/marco/RLSI033000\%20\%20 Parecer\%20AmBev.htm

BRASIL, PMSP (2003). Taxa do Lixo. Prefeitura Municipal de São Paulo Disponível http://www2.prefeitura.sp.gov.br/secretarias/financas/tributos/taxadolixo/0001

BRIEN, Richard H., Betsy D. Gelb, \& William D. Trammel (1972). The Challenge to Marketing Dominance. Business Horizons, February, pp. 23-30.

BUTLER, Rachael (2000). PET Primps for the Party. Beverage World, 19 (1691), p. 56 (4 p.)

CALDERONI, Sabetai (1997). Os Bilhões Perdidos no Lixo. São Paulo, Brasil: Humanitas.

CEPAL \& PNUMA (2002). La Sostenabilidad del Desarollo en América Latina y el Caribe: Desafíos y Oportunidades. Santiago de Chile: Comissão Econômica para América Latina e Caribe; Programa das Nações Unidas para o Meio Ambiente.

CHISNALL, Peter M. (1995). Consumer Behaviour. London: McGraw-Hill Book Company, Third Edition.

CODDINGTON, Walter (1993). Environmental marketing: positive strategies for reaching the green consumer. USA: McGraw-Hill, Inc.

CONNER, Kathleen R. (1991). A Historical Comparison of Resource-Based Theory and Five Schools of Thought Within Industrial Organization Economics: Do We Have a New Theory of the Firm? Journal of Management, 17 (1), pp. 121-154.

CRAVENS, David W. (1994). Strategic Marketing. USA: Irwin, $4^{\text {th }}$ edition. 
DATAMARK (2003). Brazil Pack’03.

DEFRA (2001a). The Producer Responsibility Obligations (Packaging Waste) Regulations 1997: Recovery and Recycling Targets for Packaging Waste in 2001 (Regulatory Impact Assessment). Department for Environment, Food \& Rural Affairs.

(2001b). Envirowise - Business and the Environment. Department for $\begin{array}{lllll}\text { Environment, } & \text { Food } \quad \text { \& } & \text { Rural } & \text { Affairs. } & \text { Disponível }\end{array}$ http://www.defra.gov.uk/environment/ envirowise/index.htm

DETR (2000). Waste Strategy 2000 for England and Wales. Department of the Environment, Transport and the Regions.

EC (1994). European Parliament and Council Directive 94/62/EC of 20 December 1994 on Packaging and Packaging Waste. Official Journal L 365, 31/12/1994 pp. $10-23$.

ELLIOTT, Richard and Kritsadarat Wattanasuwan (1998). Brands as Symbolic Resources for the Construction of Identity. International Journal of Advertising, 17 (2), pp. 131-144.

EMBALAGEMMARCA (2001a). Cada vez mais, reciclar poderá ser um bom negócio. Março, 2001, pp. 23-30 (2001b). “Discussão aberta a todos”. Setembro, 2001, pp. 813

(2002). Emergentes quebram o gelo. Novembro, 2002, pp. 6-

(2003a). Ousadia da Cerpa. Fevereiro, 2003, pp. 36-37

(2003b). Sem medo do frio. Junho, 2003, pp. 14-17 
(2003c). O aço se une para vender mais. Junho, 2003, pp. 6-

12

ENGEL, James F., Blackwell, Roger D. \& Miniard, Paul W. (1994). Consumer behavior. USA: The Dryden Press, $8^{\text {th }}$ edition.

ETBPB (2000). Packing Line Savings in the Food and Drink Industry. UK Environmental Technology Best Practice Programme.

EUWID (2002). UNEP Study on Progress Made on Sustainability Since The Rio Summit. Recycling and Waste Management 8 (11), Europäischer Wirtschaftdienst, p. 15

FERNIE, John \& Cathy Hart (2001). UK Packaging Waste Legislation: Implications for Food Retailers. British Food Journal, 103 (3) pp. 187-197.

FISHBEIN, Bette K. (2000). Carpet Take-Back: EPR American Style. Environmental Quality Management 10 (1) pp. 25-36.

FOOD ENGINEERING (2000). Voila! Beer in Oxygen-Barrier PET Ready to Roll. 72 (9), p. 30

FREY, Bruno S. (1999). Morality and Rationality in Environmental Policy. Journal of Consumer Policy 22, pp. 395-417.

FSP (2003). Pequenos 'reis da sucata' lucram alto. Folha de S. Paulo - Caderno Folha Negócios, 31/08/2003

FT (2002). Move for £5 Rubbish Tax. Financial Times, 12/07/2002

GOODWIN, Neva R. (2001). Taming the Corporation - Overview Essay, in HARRIS, Jonathan M., Timothy A. Wise, Kevin P. Gallagher \& Neva R. Goodwin. A Survey of Sustainable Development. USA: Island Press (pp. 261275). 
GPI (sem data). Glass Packaging Institute. Disponível em http://www.gpi.org/ Envio.html

GRISI, Celso Cláudio de Hildebrand, Ricardo Pitelli Britto, Seiso Arima \& André Chimeri Battaglia (2003). Logística Reversa. São Paulo: USP/FEA/PPGA (CDROM).

HANDELMAN, Jay M. \& Stephen J. Arnold (1999). The Role of Marketing Actions with a Social Dimension: Appeals to the Institutional Environment. Journal of Marketing, 63 (July), pp. 33-48.

HARRIS, Jonathan (2001). Economics of Sustainability: the Environmental Decision - Chapter Overview, in HARRIS, Jonathan M., Timothy A. Wise, Kevin P. Gallagher \& Neva R. Goodwin. A Survey of Sustainable Development. USA: Island Press (pp. 3-14).

\& Neva R. Goodwin (2001). Volume Introduction, in HARRIS, Jonathan M., Timothy A. Wise, Kevin P. Gallagher \& Neva R. Goodwin. A Survey of Sustainable Development. USA: Island Press (pp. xxvii-xxxvii).

HITCHENS, David, Esmond Birnie, William Thompson, Ursula Triebswetter, Paolo Bertossi \& Luciano Messori (2000). Environmental Regulation and Competitive Advantage: A Study of Packaging Waste in the European Supply Chain. Celtenham, UK: Edward Elgar.

HOLBROOK, Morris B. \& Elizabeth C. Hirschman (1995 [1982]). The Experiential Aspects of Consumption: Consumer Fantasies, Feelings, and Fun, in Enis, Ben M., Keith K. Cox, and Michael Mokwa (eds.) Marketing Classics: A Selection of Influential Articles. New Jersey: Prentice Hall, pp. 179-191.

HOWARD, John A. \& Jagdish N. Sheth (1995 [1967]). A Theory of Buyer Behavior, in Enis, Ben M., Keith K. Cox \& Michael Mokwa (eds.) Marketing Classics: A Selection of Influential Articles. New Jersey: Prentice Hall, pp. 137-155. 
INTERPACK (2002). Beverage Packaging: Competition Stirs up Some Exciting Developments. Press Information, $16^{\text {th }}$ International Fair Packaging Machinery, Packaging, Confectionery Machinery, Düsseldorf, 24-30/04/02.

JUCHEM, Peno Ari (1995). Gestão e Auditoria Ambiental. Curitiba: FAE/CDE Faculdade Católica de Administração e Economia/Centro de Desenvolvimento Empresarial.

KAISER (2003). Site corporativo, http://www.kaiser.com.br

KALAFATIS, Stavros P., Michael Pollard, Robert East \& Markos H. Tsogas (1999). Green Marketing and Ajzen's Theory of Planned Behaviour: A Cross-Market Examination. Journal of Consumer Marketing, 16 (5), pp. 441-460.

KAPFERER, Jean-Noël (1997). Strategic Brand Management: Creating and Sustaining Brand Equity Long Term. London: Kogan Page.

KATONA, George (1995 [1953]). Rational Behavior and Economic Behavior, in Enis, Ben M., Keith K. Cox \& Michael Mokwa (eds.) Marketing Classics: A Selection of Influential Articles. New Jersey: Prentice Hall, pp. 125-136.

KLEIN, Naomi (2000). No Logo. London: Flamingo.

KOTLER, Philip \& Gary Armstrong (1998). Princípios de Marketing. Rio de Janeiro: Editora Prentice-Hall do Brasil, $7^{\mathrm{a}}$ edição.

LEVY, Geoffrey (editor) (2000). Packaging, Policy and the Environment. Maryland: Aspen Publishers, Inc.

LIVINGSTONE, Susan \& Leigh Sparks (1994). The New German Packaging Laws: Effects on Firms Exporting to Germany. International Journal of Physical Distribution \& Logistics Management, 24 (7), pp. 15-25. 
MACHADO Fo, Cláudio Antonio Pinheiro (2002). Responsabilidade Social Corporativa e a Criação de Valor para as Organizações: um Estudo Multicasos. Tese de doutorado.

MAINIERI, Tina, Barnett, Elaine G., Valdero, Trisha R., Unipan, John B. \& Oskamp, Stuart (1997). The Influence of Environmental Concern on Consumer Behavior. The Journal of Social Psychology, 1997, 137 (2), pp. 189-204.

MARSHALL, C. \& G. Rossman (1995). Designing qualitative research. Newbury Park, CA: Sage Publications

MARTINS, Osvaldo Stella (1999). Análise de Ciclos de Vida como Contribuição à Gestão Ambiental de Processos Produtivos e Empreendimentos Energéticos. Dissertação de Mestrado.

MATHIOS, Alan (1999). The Economics of Morality and Environmental Policy: Comment on the Paper by Frey. Journal of Consumer Policy 22, pp. 429-434.

MAXWELL, Joseph A. (1996). Qualitative research design: an interactive approach. Thousand Oaks: Sage Publications.

MAY, Peter H. (editor) (1999). Natural Resource Valuation and Policy in Brazil Methods and Cases. New York: Columbia University Press.

McINTOSH, Malcolm, Deborah Leipziger, Keith Jones, and Gill Coleman, 1998). Corporate Citizenship: Successful Strategies for Responsible Companies. London: Financial Times-Pitman Publishing.

METALIC (2003). Disponível em http://www.metalic.com.br/metalic.html

MENDES, Alessandro (2003). Como explorar os conceitos do ecodesign. Palestra proferida durante a $5^{\text {a }}$ Semana Abre do Design de Embalagem. São Paulo, 08/10/2003. 
MILES, Matthew B., and A. Michael Huberman (1994). Qualitative Data Analysis: an Expanded Sourcebook. Thousand Oaks, California; London: Sage.

MINTEL (2001a). Lager. Market Intelligence. Mintel International Group Ltd. (2001b). The UK Food and Drink Packaging Market Development. Market Intelligence. Mintel International Group Ltd.

(2002). Food \& Drink Packaging (Industrial Report). Mintel International Group Ltd.

MORGAN, Rory P. (2000). A Consumer-Orientated Framework of Brand Equity and Loyalty. International Journal of Market Research, 42 (1), pp. 65-78.

MURRAY, Robin (1999). Creating Wealth from Waste. London: Demos.

NYBORG, Karine (1999). Informational Aspect of Environment Policy Deserves More Attention: Comment on the Paper by Frey. Journal of Consumer Policy 22, pp. 419-427.

ONU (2001). Contabilidade da Gestão Ambiental: Procedimentos e Princípios. Assuntos Económicos \& Sociais. Nova Iorque: Nações Unidas.

OTTMAN, Jacquelyn A. (1998). Green Marketing: Opportunity for Innovation in the New Marketing Age. NTC Business Books, $2^{\text {nd }}$ Edition.

PACK REPORT (2002). Aktive und Passive Barrieren. April, pp. 107-110.

PACKAGING DIGEST (2000). Swedes Say 'Skal' to Brew in PET Bottles Coated with ‘Glass-Like’ Process. 37 (4), p. 32.

PACKAGING TECHNOLOGY \& ENGINEERING (1998). Pechiney Uncorks Multilayer Plastic Beer Bottle for Bass. 7 (2), p. 7.

PEARCE, David, Anil Markandya \& Edward Barbier (1992). Blueprint for a Green Economy. London: Earthscan Publications Ltd. 
PEATTIE, Ken (1992). Green Marketing. London: Pitman Publishing.

(1999). Trapping versus Substance in the Greening of Marketing Planning. Journal of Strategic Marketing, 7, pp. 131-148.

(2001). Towards Sustainability: The Third Age of Green Marketing. The Marketing Review, 2, pp. 129-146.

POLONSKY, Michael Jay \& Phillip J. Rosenberger III (2001). Reevaluating Green Marketing: A Strategic Approach. Business Horizons, September-October, pp. 21-30.

PORTER, Michael E. \& Claas van der Linde (1995). Green and Competitive: Ending the Stalemate. Harvard Business Review, 73 (5), pp. 120-133.

RESEARCH INTERNATIONAL (2002). Observatório RI - Reciclagem de Materiais.

ROWAN, Claire (2001). Glass. Food Engineering and Ingredients, 26 (4), June, pp. 30-34.

SCHINCARIOL (2003). Site corporativo, http://www.schincariol.com.br

SEN, Sankar, Gürhan-Canli, Zeynep \& Morwitz, Vicki (2001). Withholding Consumption: A Social Dilemma Perspective on Consumer Boycotts. Journal of Consumer Research, 28, December, pp. 399-417.

SHLEIFER, Andrei \& Robert W. Vishny (1997). A Survey of Corporate Governance. The Journal of Finance, LII (2), June, pp. 737-783.

SINDICERV (2003). Disponível em http://www.sindicerv.com.br

SKINNER, Burrhus F. (1974). Ciência e Comportamento Humano. São Paulo: Edart/Edusp. 
SMITH, Chris \& Peter White (2000). Life Cycle Assessment of Packaging, in LEVY, Geoffrey (editor). Packaging, Policy and the Environment. Maryland: Aspen Publishers, Inc., pp. 178-204.

STERN, Paul C. (1999). Information, Incentives, and Proenvironmental Consumer Behavior. Journal of Consumer Policy, 22, pp. 461-478.

STEWART, Alex (1998). The ethnographer's method. Qualitative Research Methods Series, Vol. 46. Thousand Oaks: Sage Publications.

STRAUGHAN, Robert D. \& James A. Roberts (1999). Environmental Segmentation Alternatives: a Look at Green Consumer Behavior in the New Millennium. Journal of Consumer Marketing, 16 (6), pp. 558-575.

THØGERSEN, John (1999). The Ethical Consumer. Moral Norms and Packaging Choice. Journal of Consumer Policy 22, pp. 439-460.

TOLEKEN, Steve (1999). Cost Could Curb Thirst for Beer in PET Bottles. Plastic News, 11 (6) p. 5 (2 p.)

TONNER, Klaus (2000). Consumer Protection and Environmental Protection: Contradictions and Suggested Steps Towards Integration. Journal of Consumer Policy, 23, pp. 63-78.

UUSITALO, Liisa (1999). Do the Same Models Apply to Consumers and Business Firms? Comments on the Paper by Frey. Journal of Consumer Policy 22, pp. 435-438.

WAGNER, Sigmund A. (1997) Understanding Green Consumer Behaviour: A Qualitative Cognitive Approach. London: Routledge.

WALCZYK, Doris (2001). Packaging Should be Critical Element in Branding Scheme. Marketing News, 5 November, p. 14. 
WCED (1987). Our Common Future, The World Commission on Environment and Development - ‘Brundtland Report’. Oxford University Press.

WEGGEMAN, Peter (2000). The Beer Bottle Plan Driver, Technology, Compromises. Beverage Industry, 91 (9), January, p. 36.

(2001). Building better beverage packaging. Beverage Industry, 92 (1), January, p. 32.

WELLS, Christopher (2000). Packaging and environmental policies - Brazil, in LEVY, Geoffrey (editor). Packaging, Policy and the Environment. Maryland: Aspen Publishers, Inc., pp. 369-391

WILLIAMSON, Gabrielle H. (2000). Packaging and environmental legislation - the European Community, in LEVY, Geoffrey (editor). Packaging, Policy and the Environment. Maryland: Aspen Publishers, Inc., pp. 131-152.

YIN, Robert K. (1994). Case study research: design and methods. Sage Publications. ZOLTAK, James (2001). Beers to You: Future Becoming Clearer for Plastic Beer Bottles. Amusement Business, 13 (35), p. 14. 


\section{BIBLIOGRAFIA DE APOIO}

BARTON, John, Darren Perrin \& Jenniffer Barton (orgs.) (2001). The Millennium Recycling Scheme: Results and Analysis. School of Civil Engineering, The University of Leeds.

BURNLEY, Stephen \& Julian Parfitt (2000). Public Attitudes to Waste and Waste Management. Department of Environmental and Mechanical Engineering, The Open University.

CARSON, David, Gilmore, Audrey, Perry, Chad \& Gronhaug, Kjell (2001). Qualitative Marketing Research. London: Sage Publications.

CHEN, Chialin (2001). Design for the Environment: A Quality-Based Model for Green Product Development. Management Science, 47 (2), pp. 250-263.

DAY, George S. and Robin Wensley (1988). Assessing Advantage: A Framework for Diagnosing Competitive Superiority. Journal of Marketing, 52, April, pp. 1-20.

DEFRA (2002). Municipal Waste Management Statistics 2000/01. Department for Environment, Food \& Rural Affairs.

DU GAY, Paul and Graeme Salaman (1992). The Cult[ure] of the Customer. Journal of Management Studies, September, 29 (5), pp.613-633.

EC (2001). European Commission DGXI.E.3 - European Packaging Waste Management Systems. Final Report, February.

EDVARDSSON, Bo, Michael D. Johnson, Anders Gustafsson, and Tore Strandvik (2000). The Effects of Satisfaction and Loyalty on Profits and Growth: Products Versus Services. Total Quality Management, 11 (7), pp. s917-s927.

ENVIRONMENTAL AGENCY (2002). Packaging Materials. http://www. environment-agency.gov.uk 
EUWID (2002b). UK Packaging Waste Targets for 2002. Recycling and Waste Management 8 (6), Europäischer Wirtschaftdienst, p. 16.

(2002c). MEP Corbey Tables Draft Report on the Revision of the Packaging Directive. Recycling and Waste Management 8 (7), Europäischer Wirtschaftdienst, pp. 1-2.

(2002d). The Wastepack Group Fails to Meet its Waste Packaging Recovery Obligation. Recycling and Waste Management 8 (8), Europäischer Wirtschaftdienst, pp. 5-6.

(2002e). UK Government Misses Packaging Waste Targets. Recycling and Waste Management 8 (10), Europäischer Wirtschaftdienst, p. 14.

(2002f). EU Environment Ministers Agree on Revised Packaging Directive Targets. Recycling and Waste Management 8 (13), Europäischer Wirtschaftdienst, p. 1.

FEATHERSTONE, Mike (1991). Consumer Culture and Postmodernism. London: Sage Publications.

HEDLEY, Barry (1984 [1976]). A fundamental approach to strategy development. In WEITZ, Barton A. \& Robin Wensley. Strategic marketing: planning, implementation, and control. Boston, USA: Kent Publishsing Company (pp. 149165)

HOSKISSON, Robert E., Michael A. Hitt, William P. Wan, and Daphne Yiu (1999). Theory and Research in Strategic Management: Swings of a Pendulum. Journal of Management, 25 (3), pp. 417-456.

INCPEN (2002). Industry Council for Packaging and the Environment. Disponível http://www.incpen.org/html/recycling_fact.htm)

KAY, John (1995). Why Firms Succeed. New York: Oxford University Press. 
LYONS, Evanthia, David Uzzell, and Lesley Storey (2001). Surrey Waste Attitudes \& Actions Study: Final Report. Social Psychology European Research Institute, Department of Psychology, School of Human Sciences, University of Surrey.

McGOLDRICK, Peter (2002). Retail Marketing. Glasgow: McGraw-Hill, $2^{\text {nd }}$ edition.

McGAHAN, Anita M. and Michael E. Porter (1997). How Much does Industry Matter, Really? Strategic Management Journal, 18 - Summer Special Issue, pp. 15-30.

McLEAN, Allan (sem data). A Tour for Your Taste Buds. British Beer \& Pub Association. Disponível www.beerandpub.com/newpages/sec1newp/beertype

MINTEL (2000a). Bottled Lager. Mintel International Group Ltd. (2000b). Canned Lager. Mintel International Group Ltd. (2000c). Food and Drink Packaging. Market Intelligence. Mintel International Group Ltd. (2001c). Impact of Cross-Channel Shopping on UK Alcohol Market. Market Intelligence. Mintel International Group Ltd. (2002b). Ales and Stouts. Mintel International Group Ltd. (2002c). Attitudes Towards Drinking. Mintel International Group Ltd.

MORI (2000). Stakeholder Dialogue: Consumer Attitudes. Market and Opinion Research International, http://www.csreurope.org/csr_europe/Activities/ Dialogue/Mori.htm

PORTER, Michael E. (1985). Competitive Advantage: Creating and Sustaining Superior Performance. New York: The Free Press.

PROCTOR, Tony (2000). Strategic Marketing: An Introduction. London: Routledge. 
REICHHELD, Frederick F. (1996). The Loyalty Effect: The Hidden Force Behind Growth, Profits, and Lasting Value. Boston: Harvard Business School Press.

, Robert G. Markey Jr., and Cristopher Hopton (2000). The Loyalty Effect - The Relationship Between Loyalty and Profits. European Business Journal, 3 (2), pp. 134-9.

RUMELT, Richard P. (1991) How Much does Industry Matter? Strategic Management Journal, 12, pp. 167-185.

, Dan E. Schendel, and David J. Teece (1994). Fundamental Issues in Strategy, in Rumelt, Richard P., Dan E. Schendel, and David J. Teece (eds.). Fundamental Issues in Strategy. Harvard Business School Press, pp. 9-47.

RYAN, Gery W. and H. Russel Bernard (2000). Data Management and Analysis

Data, in Norman K. Denzin and Yvonna S. Lincoln (eds.) Handbook of Qualitative Research. California: Sage Publications, $2^{\text {nd }}$ Edition, pp.769-802.

SEEG (2001). Consultation Paper on Recovery and Recycling Targets for Packaging Waste in 2002. Scottish Executive Environment Group, October.

SILVERMAN, David (2000). Analyzing Talk and Text, in Norman K. Denzin and Yvonna S. Lincoln (eds.) Handbook of Qualitative Research. California: Sage Publications, $2^{\text {nd }}$ Edition, pp. 821-834.

SLATER, Don (1997). Consumer Culture and Modernity. Cambridge: Polity Press.

SI 648 (1997) - Statutory Instrument 1997 No. 648. The Producer Responsibility Obligations (Packaging Waste) Regulations 1997.

SI 1165 (1998) - Statutory Instrument 1997 No. 1165. The Packaging (Essential Requirements) Regulations 1998. 
SI 1361 (1999) - Statutory Instrument 1999 No. 1361. The Producer Responsibility Obligations (Packaging Waste) (Amendment) (England and Wales) Regulations 1999.

SI 2275 (2000) - Statutory Instrument 2000 No. 3375. The Producer Responsibility Obligations (Packaging Waste) (Amendment) (England and Wales) Regulations 2000.

SSI 451 (2000) - Scottish Statutory Instrument 2000 No. 451. The Producer Responsibility Obligations (Packaging Waste) (Amendment) (Scotland) Regulations 2000.

TEECE, David J., Pisano, Gary \& Shuen, Amy (1997). Dynamic Capabilities and Strategic Management. Strategic Management Journal, 18 (7), pp. 509-533.

THORNE, Sally (1994). Secondary Analysis in Qualitative Research: Issues and Implications, in Janice M. Morse (ed.) Critical Issues in Qualitative Research Methods. California: Sage Publications, pp. 263-279.

TOLEDO, Geraldo Luciano \& HEMZO, Miguel Angelo. O processo de posicionamento e o marketing estratégico. FEA/USP, 1994 


\begin{abstract}
ANEXO 1
Pergunta de pesquisa:

$\rightarrow$ COMO O MARKETING “VERDE” TEM AFETADO AS DECISÕES SOBRE

EMBALAGEM TOMADAS NAS CERVEJARIAS QUE ATUAM NO BRASIL?

\section{Objetivos:}

$\rightarrow$ Principal: Identificar o impacto que o comportamento "verde" do consumidor está tendo nessas decisões

$\rightarrow$ Secundários: (a) Identificar os fatores que influenciam as cervejarias nas suas decisões sobre embalagens, levantando a importância relativa de cada fator; e (b) identificar se pode haver mudanças na divisão desse mercado entre os diferentes materiais de embalagens (haveria espaço para o PET, por exemplo?)
\end{abstract}

\title{
Roteiro de Entrevista:
}

1. Estrutura de tomada de decisão sobre embalagens.

2. Quais as marcas de que cuida. Participação de mercado

3. Tipos de embalagem usadas.

- Share (aproximado, se não tiver dados/não revelar) de cada uma

- Diferenças por canal?

- Diferenças na forma como o consumidor percebe cada embalagem?

- Há planos para incluir novas opções (PEN ou PET, aço - se ainda não usar - e stubbies)? O que uma mudança como essa implica?

4. Fatores importantes na escolha de embalagens (se possível, ordenar).

- Custo

- Imagem 
- Exigências do canal

- Fatores técnicos (ex: linhas de enchimento existente)

- Preferências do consumidor

- Impacto ambiental

- Outros

5. Importância da embalagem na estratégia de posicionamento da marca

$\rightarrow$ EXPLORAR!

6. Sobre que atributos está posicionada a marca? Valores da marca?

7. Atitudes dos consumidores consideradas ao decidir sobre os tipos de embalagens.

- Busca por praticidade

- Individualismo

- Preocupação com o corpo

- Outras

8. Alguma nova tendência (em termos de atitude) surgindo? Algum segmento novo se delineando para os próximos 5 anos?

- Produtos orgânicos

- Busca por produtos light

- Meio ambiente $\rightarrow$ se não aparecer, perguntar especificamente (consumerismo “verde”)

9. Novas tendências de consumo?

- Consumidores mais jovens

- Público mais feminino

- Novos locais de consumo

- Consumidor "verde”? $\rightarrow$ EXPLORAR! 
10. Sobre o descarte das embalagens usadas: Como a empresa está se preparando para responder a uma eventual responsabilização pela coleta e destinação das embalagens descartadas?

11. Algum material específico pode se beneficiar?

12. Sindicerv favorável à retornável de $600 \mathrm{ml}$. Posição da empresa?

- Empecilho: supermercados

13. Participação da área de marketing/embalagens nas discussões sobre meio ambiente e desenvolvimento sustentável.

14. Faz ACV ou algum tipo de contabilidade ambiental? O departamento participa?

15. Atuação ambiental da empresa

$\rightarrow$ EXPLORAR! 